College of William \& Mary Law School William \& Mary Law School Scholarship Repository

2006

\title{
Procuring Guilty Pleas for International Crimes: The Limited Influence of Sentencing Discounts
}

Nancy Amoury Combs

William \& Mary Law School, ncombs@wm.edu

\section{Repository Citation}

Combs, Nancy Amoury, "Procuring Guilty Pleas for International Crimes: The Limited Influence of Sentencing Discounts" (2006).

Faculty Publications. 36.

https://scholarship.law.wm.edu/facpubs/36

Copyright c 2006 by the authors. This article is brought to you by the William \& Mary Law School Scholarship Repository. https://scholarship.law.wm.edu/facpubs 


\section{Procuring Guilty Pleas for International Crimes: The Limited Influence of Sentence Discounts}

Nancy Amoury Combs

59 Vand. L. Rev. 69 (2006)

International tribunals prosecuting those responsible for genocide, crimes against humanity, and war crimes face many of the same resource constraints that bedevil national criminal justice systems. Consequently, international tribunals have begun to utilize various procedural devices long used by national prosecutors to speed case dispositions. One such procedural device is the guilty plea. National prosecutors induce criminal defendants to plead guilty and waive their rights to trial through a process of plea bargaining; that is, by offering defendants sentencing concessions in exchange for their guilty pleas. International prosecutors who seek to engage in plea bargaining, however, face a host of impediments unknown to domestic prosecutors. Most important of these is that some groups of international defendants do not significantly value the sentencing concessions that form the heart of plea bargaining in national criminal justice systems. This Article explores the role of sentencing discounts in the guilty-plea decisions of international defendants, and it reveals that while sentencing discounts play the primary role in influencing Western defendants charged with domestic crimes to plead guilty, those same discounts often have relatively little effect on the guilty-plea decisions of various groups of international defendants. Indeed, whether the prospect of sentence leniency will motivate an international defendant to plead guilty depends on a number of eclectic and sometimes unexpected factors, including the nature of the crime, the nature of the prosecutorial selection process, the background of defense counsel, the status and education of the defendants, and the defendants' cultural views about crime and its appropriate punishment. The study in its entirety reveals that the wholesale transplantation of plea bargaining practices that successfully procure guilty pleas in the context of domestic prosecutions is likely to prove inefficient and ineffective in the context of many international prosecutions. 


\title{
Procuring Guilty Pleas for International Crimes: The Limited Influence of Sentence Discounts
}

\author{
Nancy Amoury Combs ${ }^{\star}$
}

I. INTRODUCTION ..................................................... 70

II. Plea BARGAINING AND CRIMINAL SENTENCING

IN NATIONAL AND INTERNATIONAL CRIMINAL

JUSTICE SYSTEMS

III. THE SUBSTANTIAL INFLUENCE OF SENTENCING

DisCOUNTS IN INTERNATIONAL CASES: GUILTY

PLEAS AT THE ICTY

A. The ICTY's Early Guilty Pleas: Limited

Benefits for Defendants....

B. The Second Phase in ICTY Plea Bargaining:

Generous Concessions, Substantial Cooperation, and Judicial Displeasure

IV. THE ROLE OF IDEOLOGY IN PleA BARGAINING:

GUILTY PlEAS AT THE ICTR

A. The ICTR's Guilty-Plea Cases ........................... 103

1. Kambanda ........................................... 103

2. Serushago ............................................ 105

3. Ruggiu .............................................. 108

4. Rutaganira.......................................... 111

B. The Dearth of ICTR Guilty Pleas: The

Insignificant Influence of Sentence Discounts........ 114

V. Cultural FaCtors Influencing Plea Bargaining

AND THE PERCEPTION GAP BETWEEN DEFENDANTS AND

Their Counsel: Guilty Pleas at The SPEcial

PANELS FOR SERIOUS CRIMES

\footnotetext{
* Assistant Professor of Law, College of William \& Mary, School of Law. 1 am grateful to Bruce Combs, Mark Harmon, Jessica Holmes, Daryl Mundis, Kimberly Pronk, and Lars Waldorf for commenting on an earlier version of this Article and to the numerous prosecutors and defense counsel who provided me with valuable information. Any errors are my own.
} 
A. Sentencing Discounts Through the Eyes of Special Panels Defendants

B. Enhancing the Influence of Sentencing

Discounts: The Role of Defense Counsel ................. 141

VI. CONCLUSION............................................................. 146

\section{INTRODUCTION}

Approximately 90 percent of all American criminal cases are disposed of by means of guilty pleas, ${ }^{1}$ and a large percentage of defendants brought before courts in England, Australia, and other countries that use common-law procedures likewise plead guilty. ${ }^{2}$ Why do substantial numbers of defendants in national criminal justice systems choose to convict themselves when they are entitled to have their guilt formally adjudicated? The widely accepted primary reason is that they receive sentencing discounts when they choose to selfconvict. Most defendants charged with domestic crimes plead guilty following a process of plea bargaining between defense counsel and prosecutors. Although plea bargaining can take many forms, ${ }^{3}$ at its

1. See Brady v. United States, 397 U.S. 742, 752 n.10 (1970) (relying on estimates "that about $90 \%$, and perhaps $95 \%$, of all criminal convictions are by pleas of guilty"); WAYNE R. LaFave et al., Criminal Procedure 21-22 (3d ed. 2000) (observing that no more than $15 \%$ of felony charges and only $3 \%$ to $7 \%$ of misdemeanor charges are likely to be resolved by trial); George Fisher, Plea Bargaining's Triumph, 109 YALE L.J. 857, 1012 (2000) (noting that in modern American courtrooms guilty plea rates in the neighborhood of ninety or even ninety-five percent are common); Stephen J. Schulhofer, Plea Bargaining as Disaster, 101 YALE L.J. 1979, 1993 (1992) ("[E]ighty to ninety percent of defendants currently plead guilty.").

2. See Kathy MacK \& Sharyn ROACH ANLEU, Pleading GuIlty: Issues and PRACTICES 4 \& $n .22$ (1995) (reporting that $83.5 \%$ of criminal cases in South Australia and $78 \%$ of criminal cases at the County Court of Melbourne were resolved by guilty plea); John Willis, New Wine in Old Bottles: The Sentencing Discount for Pleading Guilty, 13 LAW IN CONTEXT 39, 59 (1995) (observing that the majority of Australian defendants plead guilty); ANDREW SANDERS \& RICHARD YOUNG, CRIMINAL JUSTICE 396 (2000) (reporting that $82 \%$ of British cases were disposed of by means of guilty plea); Penny Darbyshire, The Mischief of Plea Bargaining and Sentencing Rewards, 2000 CRIM. L. REV. 895, 896 (observing "that the overwhelming majority of [English] defendants ... plead guilty"); Gail Kellough \& Scot Wortley, Bail Decisions and Plea Bargaining as Commensurate Decisions, BRIT. J. CRIMINOLOGY 186, 188 (2002) (reporting on surveys that "have revealed that over 90 per cent of all criminal cases [in Canada] are resolved before trial through a negotiated plea"); JOHN BALDWIN \& MICHAEL MCCONVILLE, JURY TRIALS 1 n. 1 (1979) (noting that "[m]ost defendants, both in England and in the United States," plead out).

3. See Malcolm M. Feeley, Perspectives on Plea Bargaining, 13 LAW \& Soc'Y REV. 199, 199-200 (1979) (noting that plea bargaining can involve "negotiation over sentence as distinct from charge, over dropping all charges as distinct from reducing them, over facts as distinct from the purely instrumental manipulation of charges [and that each form] can be implicit or explicit"). Robert Weninger, for instance, states that "[t]he widest definition of plea bargaining... includes any inducements that are offered in exchange for a defendant's 
heart is a promise of some form of sentence leniency in exchange for the defendant's guilty plea. ${ }^{4}$ In the context of domestic crimes, then, most defendants are understood to plead guilty primarily, if not exclusively, in order to obtain sentence discounts, ${ }^{5}$ and the magnitude of the available discounts will largely determine how many guilty pleas will be obtained. ${ }^{6}$ As the South Australian Court of Criminal Appeal put it:

If a plea of guilty, as distinct from remorse evidenced by such a plea, cannot be regarded as a factor in mitigation of penalty, there is no incentive, other than the demands of honesty, for an offender to admit his guilt, and experience indicates that the demands of honesty have but little influence on many of those who appear in the docks of criminal courts. In most cases, if the offender has nothing to gain by admitting his guilt, he will see no reason for doing so. ${ }^{7}$

When the crime in question is an international crime that is being prosecuted before an international tribunal, the question arises whether the prospect of a sentence reduction provides defendants with the same compelling motivation to plead guilty that it does for defendants accused of domestic crimes. After violent upheavals left thousands or hundreds of thousands dead in the former Yugoslavia, Rwanda, and East Timor, the United Nations ("UN") established criminal tribunals to prosecute some of the international crimes that were committed in those locations. ${ }^{8}$ These three tribunals-the

concession of criminal liability." Robert A. Weninger, The Abolition of Plea Bargaining: A Case Study of El Paso County, Texas, 35 UCLA L. REv. 265, 289-90 (1987).

4. E.g., LAFAVE ET AL., supra note 1, at 21 (explaining that guilty pleas arise when "the prosecution offers certain concessions in return for the defendant's entry of the plea").

5. See Steven S. Nemerson, Coercive Sentencing, 64 MINN. L. REV. 669, 675 (1980) (attributing American guilty pleas to the expectation of sentence discounts); R. v. Jones (2000) Q.C.A. 84, 2000 WL 1244498 (Austl.) (Davies JA) (asserting that in most cases a guilty plea "is evidence of an expectation on the part of the offender usually as a result of legal advice that a guilty plea will probably result in a reduced sentence"); MICHAEL ZANDER \& PAUL HENDERSON, CROWN COURT STUDY, RCCJ RESEARCH STUDY No. 19, at 146 (1993) (reporting that the majority of British defendants who plead guilty are influenced by the expected sentencing discount); $R$. v. March [2002] EWCA (Crim) 551, 2002 Crim.App. R(S) 98 (Eng.) (holding that failing to give a defendant a sentence discount following a guilty plea would discourage guilty pleas); Willis, supra note 2, at 71 ("Without precise and predictable benefits for pleading guilty, it is by no means clear that defendants and their advisers will be sufficiently reassured to change their plea."); $c f$. MACK \& ANLEU, supra note 2, at 39 (reporting on interviews with prosecutors and defense counsel who said that a sentence discount is an important factor motivating defendants to plead guilty but is not always the most important factor).

6. Cf. Albert W. Alschuler, Plea Bargaining and Its History, 13 L. \& Soc'Y REv. 212, 235 (1979) ("The high rates of guilty pleas in the 1920s left little room for dramatic increases. In recent years, however, prosecutors may have found it necessary to offer greater concessions simply to keep those rates constant.").

7. R. v. Shannon (1979) 21 S.A. St. R. 451 (Austl.).

8. S.C. Res. 827, U.N. SCOR, 48th Sess., 3217th mtg., U.N. Doc. S/RES/827 (May 25, 1993) (as amended) [hereinafter 1CTY Statute]; S.C. Res. 955, U.N. SCOR, 49th Sess., 3453d mtg., U.N. Doc. S/RES/955 \& Annex (Nov. 8, 1994) (as amended) [hereinafter ICTR Statute]; UNTAET 
International Criminal Tribunal for the former Yugoslavia ("ICTY"), the International Criminal Tribunal for Rwanda. (ICTR"), and the Special Panels for Serious Crimes in East Timor ("Special Panels")have lately experienced considerable pressure to dispose of their cases more expeditiously. To that end, international prosecutors at these institutions have been making substantial efforts to induce defendants to plead guilty, and, in particular, they have offered the kinds of sentencing concessions that would prove attractive to most defendants appearing before national courts. These offers have in many cases failed to induce international defendants to plead guilty, and this failure has in some cases necessitated a greater reliance on other, perhaps less desirable means of docket-clearing. ${ }^{9}$

Informed by a series of personal interviews that I conducted with international defense counsel and prosecutors, ${ }^{10}$ this Article analyzes efforts to obtain guilty pleas in international cases. The Article shows that the primary reason that those efforts fail in certain contexts is that sentencing discounts play only the most minor role, if they play any role at all, in the guilty-plea decisions of certain groups of international criminal defendants. Whether the prospect of sentence leniency will in fact motivate international defendants to plead guilty depends on a number of eclectic and sometimes unexpected factors, including the nature of the crime, the nature of the prosecutorial selection process, the background of defense counsel,

Regulation No. 2000/15 on the Establishment of Panels with Exclusive Jurisdiction over Serious Criminal Offenses (June 6, 2000) [hereinafter Special Panels Statute]. Other international criminal tribunals exist as well. The Special Court for Sierra Leone was established to prosecute international and domestic crimes that occurred during Sierra Leone's brutal eleven-year civil war. See S.C. Res. 1315, U.N. SCOR, 55th Sess., 4168th mtg., at 2, U.N. Doc. S/RES/1315 (Aug. 14,2000 ) (stating that "the situation in Sierra Leone continues to constitute a threat to international peace and security in the region" and directing the UN Secretary-General to negotiate with the government of Sierra Leone regarding the Special Court); Statute of the Special Court for Sierra Leone, arts. 2--5, available at http://www.sc-sl.org/scsl-statute.html [hereinafter SCSL Statute]. The UN and Cambodia have recently agreed to estabhish Extraordinary Chambers in the Courts of Cambodia to prosecute Khmer Rouge leaders, but the Chambers have not yet begun work. See Draft Agreement Between the United Nations and the Royal Government of Cambodia Concerning the Prosecution under Cambodian Law of Crimes Committed During the Period of Democratic Kampuchea, art. 1, May 22, 2003, available at http://www.womenwarpeace.org/issues/justice/docs/gares57228b.pdf. The Rome Statute establishing a permanent International Criminal Court (ICC) was signed in 1998. Rome Statute of the International Criminal Court, July 17, 1998, U.N. Doc. A/Conf.183/9 [hereinafter Rome Statute]. This Article does not discuss these institutions since they are not currently receiving guilty pleas.

9. See infra notes 70-72.

10. The footnotes identify some interviewees, but many others spoke to me on condition of anonymity. In the latter cases, if a documentary source is available, I cite it and omit any reference to the interviews. In cases in which no documentary source is available, I cite the interview, identifying the interviewee by pseudonymic initials. 
the status and education of the defendants, and the defendants' cultural views about crime and its appropriate punishment. These factors can coalesce in unforeseen ways: in the context of some largescale crimes, virtually no sentence reduction will be sufficient to motivate defendants to plead guilty, while in the context of other atrocities, no sentence reduction is necessary to motivate defendants to plead guilty.

This Article explores the role of sentencing discounts in the guilty-plea decisions of international defendants. The Article reveals that although institutions currently prosecuting international crimes are similarly structured and seek to fulfill similar mandates, dramatic differences exist regarding the way in which defendants prosecuted before these institutions value sentencing discounts. The views of 1CTY defendants, for instance, most resemble those of Western defendants appearing before national criminal courts. In particular, an ICTY defendant's expected sentence reduction appears to play a primary role in his decision whether or not to plead guilty. By contrast, the prospect of sentencing reductions does not appear to significantly influence the decisions of ICTR defendants and Special Panels defendants. Most ICTR defendants are ideologically committed to an understanding of the Rwandan conflict that precludes their pleading guilty to the commission of genocide, regardless of the sentencing benefit they might obtain by doing so. Thus, prosecutorial attempts to motivate ICTR defendants to plead guilty with the promise of sentence reductions have been largely unsuccessful. Special Panels defendants, by contrast, are culturally committed to a world view that places tremendous value on confession, apology, and reconciliation. Thus, promises of sentence reductions have been unnecessary to persuade Special Panels defendants to plead guilty since they are already inclined to do so. The analysis that follows suggests that prosecutors who seek to persuade international defendants to plead guilty must assess a multiplicity of factors and in many cases extend their inducements beyond the traditional promise of sentencing concessions.

Part II provides a brief description of plea bargaining in national courts and examines in particular the relationship between different forms of negotiation and the sentencing schemes to which those negotiations must adapt. This examination reveals that the effectiveness of a given form of plea bargaining depends largely on the way in which the sentencing of crimes in that jurisdiction is conducted; the insights of this examination are then applied to the plea bargaining and sentencing practices prevailing at the international tribunals. Part II ends by detailing the conventional 
view that most Western defendants who plead guilty to domestic crimes do so primarily to obtain sentencing concessions. Some defendants charged with international crimes likewise plead guilty primarily to obtain sentencing concessions; in particular, an examination of ICTY plea bargaining and sentencing practices, undertaken in Part III, indicates that the guilty-plea decisions of ICTY defendants, like the decisions of defendants charged with domestic crimes, are substantially influenced by the expectation of sentence reductions. Ideological commitments and race-based loyalties can serve to reduce the influence of sentencing concessions, however, as Part IV reveals through its exploration of plea bargaining efforts at the ICTR. Finally, through an examination of guilty-plea practices at the Special Panels, Part V concludes the study by illuminating the significant role that socio-economic and cultural factors can play in encouraging or discouraging international defendants to plead guilty. The study, in its entirety, reveals that the wholesale transplant of plea-bargaining practices that successfully procure guilty pleas in the context of domestic crimes is likely to prove inefficient and ineffective in the context of many international crimes.

\section{Plea Bargaining and Criminal Sentencing in National and INTERNATIONAL CRIMINAL JUSTICE SYSTEMS}

Most guilty pleas in national criminal justice systems are secured following a process of plea bargaining. Plea bargaining can take a number of forms. In most cases, the bargaining is explicit; that is, the prosecution and defense bargain openly about the concessions the defendant is to receive. Such negotiations typically concern either the sentence that will be imposed on the defendant (sentence bargaining) or the charges to which the defendant will plead guilty (charge bargaining). When engaged in sentence bargaining, the prosecutor usually agrees to recommend that the court impose a specific sentence or a narrow range of sentences. In jurisdictions where sentence bargaining is practiced, courts typically sentence in accordance with prosecutorial recommendations; ${ }^{11}$ indeed, unless a

11. American judges, for instance, virtually always follow sentence recommendations. See LAFAVE ET AL., supra note 1, at 956 (explaining that a prosecutor may "promise a certain sentence upon a guilty plea" and that the possibility is slight that the trial judge will not follow his recommendations); Albert W. Alschuler, The Trial Judge's Role in Plea Bargaining, Part I, 76 Colum. L. REV. 1059, 1065 (1976) ("Students of the criminal courts of many American jurisdictions have noted that judges almost automatically ratify prosecutorial charge reductions and sentence recommendations."); Donald G. Gifford, Meaningful Reform of Plea Bargaining: The Control of Prosecutorial Discretion, 1983 U. ILL. L. REV. 37, 38 ("[R]egardless of the articulated standard, courts rarely intervene in plea agreements."). Australian judges, by 
court follows the prosecutor's recommendations in most cases, the prosecutor will be unable to sentence bargain because the prosecutor's recommendations are valuable only to the extent that the court adheres to them. When engaged in charge bargaining, the prosecutor typically agrees to dismiss certain charges-usually the most serious-with the expectation that the defendant will receive a lower sentence as a result. ${ }^{12}$ Some jurisdictions additionally or alternatively practice implicit plea bargaining, which refers to a judicial practice of imposing lower sentences after a guilty plea than after a trial. In those jurisdictions, no bargaining needs to take place between the defense and prosecution; rather, defendants plead guilty on the expectation that the court will sentence them more leniently. ${ }^{13}$

The sort of plea bargaining that is practiced in a given jurisdiction depends on a number of considerations, the most important of which is the legislative scheme that governs the court's sentencing. As discussed in more detail below, it is generally understood that defendants accused of domestic crimes plead guilty primarily to obtain sentencing discounts; thus, to induce such a defendant to plead guilty, a prosecutor must be able to offer the defendant a fairly certain sentence reduction in exchange for his guilty plea. In many jurisdictions, the prosecutor's charging decisions enable the prosecutor to provide defendants this certainty. In particular, charge bargaining is apt to be effective when the criminal code (1) classifies criminal activity into carefully delineated, distinct crimes; and (2) constrains judicial sentencing discretion by setting forth presumptive sentencing ranges for particular crimes. California, for example, divides criminal homicide into murder ${ }^{14}$ and manslaughter. ${ }^{15}$ Murder is further

contrast, are not so inclined to sentence in accordance with prosecutorial recommendations; consequently, sentence bargaining between prosecution and defense is less common in Australia. MACK \& ANLEU, supra note 2, at 4, 26-27.

12. E.g., LAFAVE ET AL., supra note 1, at 956 (explaining that an "on-the-nose" guilty plea to one charge may be exchanged for the prosecutor's agreement to drop other charges). In many cases, the dismissed charges carry mandatory sentences higher than the range of sentences available for the remaining charges, so the dismissal of the more serious charges necessarily results in a reduced sentence. See id.; Michael Bohlander, Plea Bargaining Before the ICTY, in ESSAYS ON ICTY PROCEDURE AND EVIDENCE IN HONOUR OF GABRIELLE KIRK MCDONALD 151, 151 (Richard May et al. eds., 2001) (explaining the effect of dismissal on the overall sentence).

13. See Alschuler, supra note 11, at 1076 (describing implicit plea bargaining in the federal courts); Lawrence M. Friedman, Plea Bargaining in Historical Perspective, 13 LAW \& SoC'Y REV. 247, 253 (1979) (discussing the unspoken understanding between defendants and judges that results in defendants being better off following a guilty plea). As a British court bluntly observed: It is "trite to say that a plea of guilty would generally attract a lighter sentence. Every defendant should know that." R. v. Cain, [1976] Crim. L.R. 464 (Eng.). See also R. v. Boyd, (1980) 2 Cr.App. R(S) 234 (Eng.).

14. Murder is defined as "the unlawful killing of a human being, or a fetus, with malice aforethought." CAL. PENAL CODE § 187 (West 2006). 
subdivided into first-degree murder ${ }^{16}$ and second-degree murder, ${ }^{17}$ while manslaughter is subdivided into voluntary, ${ }^{18}$ involuntary, ${ }^{19}$ vehicular, ${ }^{20}$ and gross vehicular while intoxicated. ${ }^{21}$ Each of these crimes is punishable by a reasonably narrow range of sentences. Defendants convicted of voluntary manslaughter, for instance, must be sentenced to three, six, or eleven years' imprisonment, ${ }^{22}$ while defendants convicted of involuntary manslaughter must be sentenced to two, three, or four years' imprisonment. ${ }^{23}$ Thus, charge bargaining is effective in California because defendants are guaranteed a certain degree of certainty about their potential sentences when deciding to plead guilty.

Charge bargaining is not as effective when it comes to international crimes, however, because those crimes are broadly defined and encompass a wide range of behavior. Genocide, crimes against humanity, and war crimes constitute the core offenses over which the ICTY, ICTR, Special Panels, and other international criminal bodies have jurisdiction, ${ }^{24}$ and each of these crimes can be

15. Manslaughter is defined as "the unlawful killing of a human being without malice." Id. $\S 192$.

16. California defines first-degree murder as including "murder which is perpetrated by means of a destructive device or explosive, a weapon of mass destruction, knowing use of ammunition designed primarily to penetrate metal or armor, poison, lying in wait, torture, or by any other kind of willful, deliberate, and premeditated killing, or which is committed in the perpetration of, or attempt to perpetrate, arson, rape, carjacking, robbery, burglary, mayhem, kidnapping, train wrecking, or [other acts] or any murder which is perpetrated by means of discharging a firearm from a motor vehicle, intentionally at another person outside of the vehicle with the intent to inflict death." Id. § 189.

17. Second-degree murder is any murder that is not first-degree murder. $I d$.

18. Voluntary manslaughter is an unlawful killing without malice that occurs "upon a sudden quarrel or heat of passion." Id. § 192(a).

19. Involuntary manslaughter is an unlawful killing without malice that occurs during "the commission of an unlawful act, not amounting to felony; or in the commission of a lawful act which might produce death, in an unlawful manner, or without due caution and circumspection," with the exception of acts committed while driving a vehicle. Id. $\$ 192(\mathrm{~b})$.

20. Vehicular manslaughter encompasses a number of acts involving a vehicle, including "driving a vehicle in the commission of an unlawful act, not amounting to felony, and with gross negligence" and "driving a vehicle in the commission of a lawful act which might produce death, in an unlawful manner, and with gross negligence." Id. § 192(c)(1).

21. Gross vehicular manslaughter while intoxicated is the "unlawful killing of a human being without malice aforethought, in the driving of a vehicle, where the driving was in violation of Section 23140,23152 , or 23153 of the Vehicle Code, and the killing was either the proximate result of the commission of an unlawful act, not amounting to a felony, and witb gross negligence, or the proximate result of the commission of a lawful act which might produce death, in an unlawful manner, and with gross negligence." Id. § 191.5(a).

22. Id. § 193(a).

23. Id. § 193(b).

24. ICTY Statute, supra note 8, arts. 2-5; ICTR Statute, supra note 8, arts. 2-5; Special Panels Statute, supra note $8, \S 1.3$ (providing additionally for jurisdiction over the domestic 
committed in a multitude of ways. Persecution as a crime against humanity, for instance, can be perpetrated by means of murder, extermination, or torture. ${ }^{25}$ Persecution also encompasses arguably less serious discriminatory acts involving political, social, and economic rights, ${ }^{26}$ including those targeting property alone. ${ }^{27}$ Consequently, two defendants convicted of persecution may have engaged in vastly different criminal behavior. General Blaškić, for instance, was a military commander convicted by the ICTY of persecution for having ordered "attacks on towns and villages; murder and serious bodily injury; the destruction and plunder of property . . . ; inhuman and cruel treatment of civilians and, in particular, their being taken hostage and used as human shields; [and] the forcible transfer of civilians."28 By contrast, Dragan Kolundžija, who was also convicted by the lCTY of persecution, was a comparatively lowly shift commander in a prison camp who had only a limited ability to prevent the mistreatment of prisoners or to improve the conditions in which prisoners were held. ${ }^{29}$ Kolundžija did not himself mistreat anyone; ${ }^{30}$ rather, his conviction of persecution stemmed from his continuing to act as a shift commander despite the abuse that others perpetrated on prisoners and the appalling conditions prevailing at the camp. Similarly, disparate acts or omissions can form the basis of other international crimes. A defendant convicted of genocide, for instance, might be responsible for a handful of murders or tens of thousands of murders.

Perhaps because they must impose appropriate sentences for crimes encompassing vastly differing levels of culpability, international judges are given almost limitless discretion in sentencing. The statutes

offenses of murder, sexual offenses and torture); Rome Statute, supra note 8, art. 5 (bestowing on the ICC jurisdiction over war crimes, crimes against humanity, and genocide and, if certain conditions are met, over aggression); SCSL Statute, supra note 8, arts. 2-5 (authorizing the Special Court for Sierra Leone to exercise jurisdiction over crimes against humanity, war crimes and certain violations of Sierra Leonean law).

25. Prosecutor v. Semanza, Case No. ICTR-97-20-T, Judgment, ff 349 (May 15, 2003).

26. Prosecutor v. Kupreškić et al., Case No. IT-95-16-T, Judgment, If 615 (Jan. 14, 2000) [hereinafter Kupreškić Judgment].

27. Prosecutor v. Blaškić, Case No. IT-94-14-T, Judgment, đ 233 (Mar. 3, 2000) [hereinafter Blaškić Judgment]. The ICTY has been careful to instruct, however, that "not every denial of a human right" can constitute persecution as a crime against humanity. Kupreškić Judgment, supra note 26, I 618. It has defined persecution as "the gross or blatant denial, on discriminatory grounds, of a fundamental right, laid down in international customary or treaty law, reaching the same level of gravity as the other acts prohibited in Article 5 [of the ICTY Statute]," which addresses crimes against humanity. Id. ๆ 621.

28. Blaškić Judgment, supra note 27, at Disposition.

29. Prosecutor v. Sikirica et al., Case No. IT-95-8-T, Sentencing Judgment, ๆf 210 (Nov. 13, 2001) [hereinafter Sikirica Sentencing Judgment].

30. Id. ๆข $202,204,229$. 
and procedural rules of the ICTY and the ICTR, for instance, instruct judges to take into account various factors when sentencing, including the gravity of the offense and the individual circumstances of the defendant, ${ }^{31}$ the general practice regarding prison sentences in the courts of the former Yugoslavia and Rwanda, as well as any aggravating or mitigating circumstances. ${ }^{32}$ But that is the extent of the guidance provided to - or the constraints imposed upon-the Trial Chambers. The statutes and the rules do not provide any instruction as to the relative "gravity" of the various offenses within the Tribunals' jurisdictions, ${ }^{33}$ nor do they indicate which "individual circumstances" might be relevant to sentencing or how they might be relevant. Further, although the statutes and rules require the Trial Chambers to consider aggravating and mitigating circumstances, they fail to delineate any aggravating circumstances, and they make mention of only one mitigating circumstance: "substantial cooperation with the Prosecutor by the convicted person before or after conviction." 34 Judges at other international tribunals possess similarly broad discretion in sentencing. ${ }^{35}$

31. ICTY Statute, supra note 8, art. 24(2); ICTR Statute, supra note 8, art. 23(2).

32. ICTY R.P. \& EVID. R. 101(B)(i)-(iii) (2004); ICTR R.P. \& EvID. R. 101(B)(i)-(iii) (2004). For a critical analysis of that provision, see William A. Schabas, Sentencing By International Tribunals: A Human Rights Approach, 7 DUKE J. CoMP. \& INT'L L. 461, 480 (1997). The ICTY and ICTR have not held themselves bound by the sentencing practices of the former Yugoslavia or Rwanda. See Prosecutor v. Delalić, Case No. IT-96-21-A, Judgment, If 813 (Feb. 20, 2001); Prosecutor v. Serushago, Case No. ICTR-98-39-A, Reasons for Judgment, If 30 (Apr. 6, 2000) (observing that the Trial Chamber is obliged only to take account of the sentencing practices in Rwanda).

33. For a discussion of the ICTY's and ICTR's views on the relative gravity of various offenses, see Andrea Carcano, Sentencing and the Gravity of the Offence in International Criminal Law, 51 INT'L \& COMP. L. Q. 583 (2002) (examining whether the same act should be punished more severely when charged as a crime against humanity rather than as a war crime); see also Allison Marston Danner, Constructing a Hierarchy of Crimes in International Criminal Law Sentencing, 87 VA. L. REV. 415, 420 (arguing that "contrary to the current practice of the ICTY, judges sentencing defendants convicted of violations of international law should consider the elements of the chapeau in evaluating the harm caused by the defendants' acts").

34. ICTY R.P. \& EVID. R. 101(B)(ii); ICTR R.P. \& EVID. R. 101(B)(ii).

35. Judges of the Special Panels, for instance, are likewise instructed to consider in sentencing "such factors as the gravity of the offence and the individual circumstances of the convicted person." Special Panels Statute, supra note 8, § 10.2. Judges of the Special Court for Sierra Leone are also directed to consider the gravity of the offense and the defendant's individual circumstances, and they are instructed in addition to "have recourse to the practice regarding prison sentences in the International Criminal Tribunal for Rwanda and the national courts of Sierra Leone." SCSL Statute, supra note 8, arts. 19(1) \& (2). Special Court for Sierra Leone judges must also consider aggravating and mitigating circumstances; like the Statutes of the ICTY and ICTR, the Special Court Statute identifies no aggravating circumstances and only one mitigating circumstance: substantial cooperation with the prosecution. SCSL Statute, supra note 8 , art. 6(4). 
Whether broadly defined crimes coupled with wide sentencing discretion result in equitable punishment is open to debate. What is not debatable, however, is that broadly defined crimes coupled with wide sentencing discretion impede a prosecutor's ability to promise the defendant a certain benefit with an offer to withdraw charges. In other words, because international judges have such wide sentencing discretion, and the crimes within the Tribunals' jurisdiction are so broadly defined and so grave, a prosecutorial promise to withdraw a few charges here and there often will fail to provide a defendant adequate certainty that he is getting appropriate consideration-or any consideration at all-for his guilty plea. So long as the remaining charges are sufficiently serious, a Trial Chamber may well sentence a defendant to the same term of imprisonment to which he would have been sentenced had he not pled guilty. So, while a California defendant can plead guilty to involuntary manslaughter instead of voluntary manslaughter and be assured of a sentence reduction, a Tribunal defendant who admits to murder as a crime against humanity instead of the more serious extermination as a crime against humanity can be assured of nothing.

Charge bargaining can be effective in the international realm, then, only if the prosecution is willing to withdraw charges in a way that would fundamentally alter either the legal or the factual description of the criminal conduct. That sort of bargaining has virtually never occurred at the international tribunals. ${ }^{36}$ By and large, international prosecutors seeking to secure guilty pleas have focused their efforts not on charge bargaining but on sentence bargaining and implicit bargaining, as will be discussed in the following Parts.

Whatever forms of plea bargaining are practiced in a particular jurisdiction, the end goal of each is the same: to provide the defendant a sentencing discount as a means of convincing him to enter a guilty plea. Plea bargaining in national criminal justice systems, then, is premised on the assumption that defendants consider the offer of a sentencing discount to be a compelling inducement. The very fact that such high percentages of defendants charged with domestic crimes do choose to plead guilty upon the offer of sentencing discounts seems to prove the point. As Frank Easterbrook put it: "Defendants presumably prefer the lower sentences to the exercise of their trial rights or they would not strike the deals." 37 Indeed, American academics have constructed sophisticated economic models to predict

36. For a comprehensive treatment of ICTY charge bargaining, see NANCY AMOURY COMBS, Guilty Pleas in InTERnational CRiminal LaW (forthcoming 2006).

37. Frank H. Easterbrook, Criminal Procedure as a Market System, 12 J. LEGAL STUDIES 299, 309 (1983). 
whether an acceptable plea bargain will exist in certain situations, and these models are predicated on the assumption that defendants seek to minimize their incarceration time. ${ }^{38}$ Richard Adelstein asserts, for instance, that "the defendant will agree to a guilty plea if he perceives the cost of the sentence received upon the plea as less than the expected disutility of the trial prospect and its associated sentence."39

Whether or not most American defendants engage in precise calculations of conviction likelihood and sentencing possibilities, empirical evidence suggests that they do plead guilty largely because they expect to receive a sentence discount for doing so. Only a few American jurisdictions have made any attempt to prohibit prosecutors from offering sentencing concessions to defendants, ${ }^{40}$ but those that did so have experienced a sharp decline in their percentage of cases disposed of by means of guilty pleas. In 1975, for instance, Alaska's Attorney General prohibited his prosecutors from offering defendants charging or sentencing concessions. ${ }^{41}$ Defendants convicted at trial continued to receive longer sentences than defendants who pled guilty, ${ }^{42}$ so implicit plea bargaining persisted. Although the prohibition on charging and sentencing concessions did not cause as dramatic an increase in trial rates as many had expected, probably because implicit plea bargaining continued, ${ }^{43}$ it did cause a substantial increase. In Anchorage, for instance, trials increased by about 97 percent following the plea-bargaining ban. ${ }^{44}$ At about the same time that Alaska instituted its ban, the District Attorney in El Paso County, Texas likewise banned both charging and sentencing

38. See, e.g., William M. Landes, An Economic Analysis of the Courts, 14 J. L. \& EcoN. 61 (1971) (describing the basic behavior assumptions of the prosecutor and accused in Landes's theoretical model); Edward A. Ruttenberg, Plea Bargaining Analytically-The Nash Solution to the Landes Model, 7 AM. J. CRIM. L. 323, 330, 334 (1979) (examining the assumptions required to construct a "synthesized model of plea bargaining").

39. Richard P. Adelstein, The Negotiated Guilty Plea: A Framework for Analysis, 53 N.Y.U. L. Rev. 783, 809 (1978).

40. See Robert L. Misner, Recasting Prosecutorial Discretion, 86 J. CRIM. L. \& CRIMINOLoGY 717,752 (1996) ("Calls for the abolition of plea bargaining have been heard and ignored for more than twenty-five years.").

41. Michael L. Rubenstein \& Teresa J. White, Alaska's Ban on Plea Bargaining, 13 LAW \& SOC'Y REV. 367, 367 (1979).

42. Teresa White Carns \& John A. Kruse, Alaska's Ban on Plea Bargaining Reevaluated, 75 JUDICATURE 310, 311-12 (1992).

43. See Rubenstein \& White, supra note 41 , at 380 \& n. 18 (describing the concern of defense counsel that, if they took a hopeless case to trial, the "convicted client would have to pay the bill in the end, perhaps in the form of a longer sentence").

44. Id. at 374 . 
negotiations in felony cases. ${ }^{45}$ As in Alaska, implicit bargaining continued because guilty-plea defendants received shorter sentences than jury-trial defendants. ${ }^{46}$ The implicit bargaining was not sufficient to maintain the guilty-plea rates that existed prior to the plea bargaining ban; rather, the proportion of cases disposed of by trial almost doubled, and in three years' time, the criminal case docket had increased by 250 percent, causing delays and straining resources. ${ }^{47}$ As these examples suggest, sentencing discounts matter to American defendants. Without them, most American defendants will proceed to trial.

Empirical studies likewise indicate that a substantial proportion of defendants in the United Kingdom also plead guilty so as to obtain sentencing concessions. ${ }^{48}$ To encourage guilty pleas English laws not only require judges to consider a defendant's guilty plea in sentencing, ${ }^{49}$ but also require judges to announce when they have discounted the defendant's sentence. ${ }^{50}$ Similarly, some Australian judges were disturbed because a substantial proportion of defendants declined to tender early guilty pleas or declined to plead guilty at all because they were uncertain as to what, if any, sentencing discount they would receive. In response, the judges began establishing guidelines for sentence reductions in guilty-plea cases and have begun informing defendants as to what discount they have in fact received. ${ }^{51}$ To the same end, the Royal Commission on Criminal Justice in the United Kingdom recommended providing defendants with a reliable early indication of the maximum sentence they will receive after pleading guilty as a means of encouraging early guilty pleas. ${ }^{52}$ The

45. Weninger, supra note 3, at 275-76. See generally Sam W. Callan, An Experience in Justice Without Plea Negotiation, 13 LAW \& Soc'Y REv. 327 (1979).

46. Weninger, supra note 3 , at 295. A 1975 study of the attempt to eliminate plea bargaining in Black Hawk County, Iowa, also found that implicit plea bargaining remained following attempts to eliminate plea bargaining. Note, The Elimination of Plea Bargaining in Black Hawk County: A Case Study, 60 IowA L. REV. 1053, 1064 n.110 (1975).

47. Weninger, supra note 3 , at 277-78.

48. C. Hedderman \& D. Moxon, Magistrates' Court or Crown Court? Mode of Trial Decisions and Sentencing, in 125 HOME OFFICE RESEARCH STUDY 32 (1992) (U.K.); see also SANDERS \& YOUNG, supra note 2, at 414.

49. Criminal Justice Act, 2003, art. 144(1) (Eng.).

50. Id. art. 174(2)(d). Few judges inform the defendant of the sentence he would have received had he gone to trial, however. RALPH HENHAM, SENTENCE DISCOUNTS AND THE CRIMINAL PROCESS 18-20 (2001).

51. See R. v. Thomson \& Houlton (2000) 49 N.S.W.L.R. 383, था 21-22, 109, 135, 148-152 (Austl.) (holding that New South Wales courts should follow the practice of other courts and announce the sentencing discount bestowed on the defendant as a result of his guilty plea, and setting the discount at between 10 and $25 \%$ ).

52. REPoRT OF THE ROYAL COMMISSION ON CRIMINAL JUSTICE 112-13 (1993) (Runciman Commission). But see SANDERS \& YoUnG, supra note 2, at 422 (opining that "[a] statement that 
Scottish High Court of Justiciary concurred in this approach, observing that a Scottish statute that requires a judge to take account of a guilty plea in sentencing "is not likely to give encouragement to pleas of guilty unless accused persons and their legal representatives have some assurance as to the allowance which the court is likely to make." 53 The sentencing judgments of appellate courts in the United Kingdom are similarly premised on the assumption that defendants plead guilty in order to obtain sentencing concessions. So as not to discourage subsequent defendants from pleading guilty, appellate courts routinely reduce sentences when they determine that the trial court gave the defendant insufficient credit for pleading guilty. ${ }^{54}$ Indeed, one Court of Appeal went so far as to state that the law required the sentencing judge to give the defendant some sentencing reduction for a guilty plea no matter how strong the prosecution's case may be. ${ }^{55}$

The offer of sentencing concessions, then, is routine in nations that use guilty pleas ${ }^{56}$ because it is effective in inducing a substantial portion of criminal defendants in those nations to plead guilty. Its effectiveness stems largely from the fact that the criminal defendants in question value the sentencing concessions they expect to receive more than they value the trial rights that a guilty plea requires them to forego. How tempting an inducement a sentencing discount will be depends of course on the magnitude of the discount and the likelihood of conviction following a trial. But the premise underlying the practice of plea bargaining-that sentencing concessions substantially influence defendants' guilty-plea decisions-appears to be sound in the context of national prosecutions. It is also sound in the context of some international prosecutions. The following Part will explore the guilty-plea decisions of defendants charged with international crimes

on a plea of guilty [the judge] would impose one sentence but that on a conviction following a plea of not guilty he would impose a severer sentence is one which should never be made").

53. Du Plooy v. H.M. Advocate, High Court of Justiciary, [2003] S.L.T. 1237, 2003 WL 22257793 (Scot.).

54. See, e.g., R. v. Marsh, [2004] EWCA (Crim) 465, 2004 Crim.App. R(S) 80 (Eng.) (reducing sentence from ten years' imprisonment to eight years' imprisonment); R. v. McKeown, [2004] EWCA (Crim) 461 (Eng.) (reducing sentence from two-and-one-half years' imprisonment to two years' imprisonment); R. v. Buffrey, [1992] 14 Cr.App. R(S) 511 (Eng.) (reducing sentence from five years' imprisonment to four years' imprisonment); R. v. Skilton \& Blackham, (1982) 4 Cr.App. R(S) 339 (Eng.) (reducing robbery sentence from five years' imprisonment to three-andone-half years' imprisonment); R. v. Boyd, [1980] 2 Cr.App. R(S) 234 (Eng.) (reducing burglary sentence from three years' imprisonment to two years' imprisonment).

55. See R. v. Fearon, (1996) 2 Cr.App. R(S) 25 (Eng.).

56. Guilty pleas are most commonly available in the criminal justice systems of AngloAmerican countries that utilize adversarial criminal procedures. Nancy Amoury Combs, Copping a Plea to Genocide: The Plea Bargaining of International Crimes, 151 PENN. L. REV. 1, 4 (2002). 
in the former Yugoslavia and will reveal that these defendants, like defendants charged with domestic crimes, find sentencing discounts to be a compelling enticement.

\section{ThE SUBSTANTIAL INFLUENCE OF SENTENCING DISCOUNTS IN INTERNATIONAL CASES: GUILTY PLEAS AT THE ICTY}

War broke out in the Socialist Federal Republic of Yugoslavia in 1991, when many of its constituent republics sought independence. ${ }^{57}$ While the secessions of Croatia and Slovenia were followed by only short-lived armed conflicts, the fighting between the Serbs, Croats, and Muslims in Bosnia-Herzegovina was fierce and protracted. ${ }^{58}$ The war in Bosnia resulted in approximately 200,000 deaths, ${ }^{59}$ approximately 20,000 rapes, ${ }^{60}$ the forced relocation of more than two million people, ${ }^{61}$ and the "reappearance of concentration camps on European soil."62 In 1993, the UN Security Council determined that the situation constituted a "threat to international peace and security" and established the ICTY to prosecute those accused of committing genocide, crimes against humanity, and violations of the laws and customs of war in the territory of the former Yugoslavia after January 1, 1991. ${ }^{63}$

Plea bargaining was not practiced during the early years of the ICTY and indeed was considered by many to be a distasteful and unnecessary procedural device. The practice was considered unnecessary because so few defendants were in the dock during the

57. Prosecutor v, Krstić, Case No. IT-98-33, Judgment, ๆ 9-10 (Aug. 2, 2001) Thereinafter Krstić Judgment]. See generally M. CheRIF Bassiouni \& PETER MaNiKas, ThE LAW of THE InTERnational CRIMINAL TRIBUNAL FOR THE FORMER YugoslaVIA 25-63 (1996); Steven L. BURG \& Paul S. Shoup, The War In Bosnia-Herzegovina: EThnic Conflict and InTERnational INTERVENTION 3-127 (1999).

58. See Krstic Judgment, supra note 57, Iी 7-10 (explaining the history of the region, its ethnic composition, and the ensuing conflict).

59. Rosemary E. Libera, Divide, Conquer, and Pay: Civil Compensation for Wartime Damages, 24 B.C. INT'L \& COMP. L. REV. 291, 293 (2001).

60. Michael P. SChaRF, BALKAN Justice 52 (1997); Makau Matua, Savages, Victims, and Saviors: The Metaphor of Human Rights, 42 HARV. INT'L L.J. 201, 223 (2001).

61. 1 VIRGINIA MORRIS \& MichaEL P. SCHARF, AN INSIDER'S GUIDE TO THE INTERNATIONAL CRIMINAL TRIBUNAL FOR THE FORMER YUgOSLAVIA xiii (1995); cf. Lynn Hastings, Implementation of the Property Legislation in Bosnia-Herzegovina, 37 STAN. J. INT'L L. 221, 221 (2001) (stating that ethnic cleansing during the war "deprived millions of Bosnian citizens of their homes").

62. Developments in the Law-Introduction, 114 HARV. L. REV. 1943, 1953 (2001); see also SCHARF, supra note 60, at 31-32 (describing reports of ethnic cleansing received by the United States, Britain, and France in 1991).

63. ICTY Statute, supra note 8, art. 1. 
Tribunal's early years ${ }^{64}$ that prosecutors had little need to expedite proceedings. The practice was considered distasteful for two reasons: first, because many ICTY prosecutors hailed from civil-law countries where plea bargaining is not widely practiced, and second, because the very magnitude of the international crimes at issue made the sort of back-room negotiations that characterize the plea bargaining of less serious domestic crimes seem entirely inappropriate. During the ICTY's procedural rulemaking process, for instance, the United States proposed granting defendants full or partial testimonial immunity in exchange for their cooperation. The proposal was rejected, ${ }^{65}$ with then-ICTY President Cassese stating: "The persons appearing before us will be charged with genocide, torture, murder, sexual assault, wanton destruction, persecution and other inhuman acts. After due reflection, we have decided that no one should be immune from prosecution for crimes such as these, no matter how useful their testimony may otherwise be." 66

The landscape has changed markedly since those early days. Now, at the same time that a record number of ICTY defendants await trial, ${ }^{67}$ the UN Security Council, unhappy with the ever-increasing

64. During its first two years of existence, the ICTY had no defendants in custody. Duško Tadic was not transferred to the ICTY until 1995, and another year passed before any other indictees were transferred. Kelly Dawn Askin, The ICTY: An Introduction to its Origins, Rules and Jurisprudence, in ESSAYS ON ICTY PROCEDURE AND EVIDENCE IN HONOUR OF GABRIELLE KIRK MCDONALD 13, 15-16 (Richard May et aI. eds., 2001). The NATO peace-keeping force stationed in Bosnia initially was not instructed to arrest Tribunal indictees. See THEODOR MERON, WAR CRIMES LAW COMES OF AGE 281 (1998); Payam Akhavan, Justice in The Hague, Peace in the Former Yugoslavia? A Commentary on the United Nations War Crimes Tribunal, 20 HUM. RTS. Q. 737,795-96 (1998) (discussing the international community's "unwilling[ness] to make the sacrifices necessary to arrest indicted persons"); Gabrielle Kirk McDonald, Reflections on the Contributions of the International Criminal Tribunal for the Former Yugoslavia, 24 HASTINGS INT'L \& COMP. L. REV. 155, 160 (2001). It was not until mid-1997 that the UN force in Croatia and then NATO in Bosnia began detaining indictees. Id. at 161.

65. See Prosecuting and Defending Violations of Genocide and Humanitarian Law: The International Tribunal for the Former Yugoslavia, 88 PROC. AM. SOC. INT'L L. 239, 248 (1994) (remarks of Steven J. Lepper) ("Among the suggestions rejected by the Tribunal was our thought that some sort of immunity or plea-bargaining mechanism should be instituted.").

66. SCHARF, supra note 60 , at 67 .

67. The UN Detention Center is "almost at full capacity," now holding more than sixty defendants, a record number. See Record Number of Detainees in The Hague, SENSE NEWS AGENCY, Apr. 6, 2004. Even today, however, the ICTY frequently fails to receive adequate cooperation from the States of the former Yugoslavia. See ICTY Office of the Prosecutor Press Release, Address by Carla Del Ponte, Prosecutor of the International Criminal Tribunal for the former Yugoslavia to the United Nations Security Council, U.N. Doc. CDP/P.I.S./917-e, (Nov. 23, 2004) ("The first obstacle is the lack of co-operation of States, mainly in the arrest and transfer of persons indicted by the ICTY."). Nevertheless, an increasing number of defendants began to be transferred to the UN Detention Center after the United States and European governments exerted substantial economic and political pressure to achieve that result. See Human Rights Watch, Real Progress in The Hague, Mar. 29, 2005, available at http://hrw.org/english/docs 
budgets of the ICTY and ICTR, ${ }^{68}$ is pressuring both Tribunals to complete their trials within the next few years. ${ }^{69}$ To comply with these demands, both the ICTY and the ICTR have drastically reduced the number of investigations they planned to conduct, ${ }^{70}$ and the Tribunals have made plans to transfer some of their cases to national

/2005/03/29/serbia 10386.htm. Indeed, Serbia agreed to transfer Slobodan Milošević to the ICTY for trial only after the United States threatened to withhold approximately $\$ 500,000$ in aid. Jack Goldsmith, The Self-Defeating International Criminal Court, 70 U. CHI. L. REV. 89, 93 (2003).

68. In 2004, the ICTY's two-year budget totaled nearly $\$ 273$ million. The ICTY at a Glance, http://www.un.org/icty/glance/index.htm (last visited Jan. 31, 2006). The ICTR's 2004-2005 budget totaled more than $\$ 227$ million. ICTR General Information, http://www.ictr.org /default.htm (last visited Jan. 31, 2006).

69. See S.C. Res. 1503, U.N. SCOR, 4817th mtg., at 3, U.N. Doc. S/RES/1503 (Aug. 28, 2003) (requesting that the Tribunals take all possible measures to complete investigations by 2004); S.C. Res. 1534, U.N. SCOR, 4935th mtg., U.N. Doc. S/RES/1534 (Mar. 26, 2004) (calling on the Tribunals to "complete all work in 2010"); see also ICTY Press Release, Judge Claude Jorda, President of the International Criminal Tribunal for the Former Yugoslavia, Reports on the Continued Non-Cooperation by the Federal Republic of Yugoslavia to the Security Council, U.N. Doc. JDH/P.I.S./706-e, Oct. 23, 2002, available at http://www.un.org/icty/pressreal/p706-e.htm (then-ICTY President Jorda noting that the Security Council "expressly mandated us to concentrate our work on the trial of the main civilian, military, and paramilitary leaders, in particular, so as to be able to complete our trial activities by around 2008"); ICTY Press Release, Address by the Prosecutor of the International Criminal Tribunals for the Former Yugoslavia and Rwanda, Mrs. Carla Del Ponte, to the United Nations Security Council, U.N. Doc. JJJ/P.I.S/709-e, Oct. 30, 2002, available at http://www.un.org/icty/pressreal/p709-e.htm (referring to "the completion strategy targets and the deadlines expected of us") [hereinafter Del Ponte 2002 Address].

70. See Del Ponte 2002 Address, supra note 69 ("I have drastically prioritised our investigative objectives, for both Tribunals, and further focused our efforts on 'the main eivilian, military and paramilitary leaders' so tbat we can now reasonably expect to fulfil the essence of our prosecution missions for both Tribunals by the end of 2004."); Report of the International Tribunal for the Prosecution of Persons Responsible for Serious Violations of International Humanitarian Law Committed in the Territory of the Former Yugoslavia since 1991, Summary I 6, U.N. Doc. A/57/150 (Aug. 4, 2002) [hereinafter ICTY 2002 Annual Report] (noting the ICTY's efforts to further "focus... [its] mission on trying those crimes which most seriously violate international public order"). For a discussion of the ICTR's reduction in investigations, see Letter dated 30 April 2004 from the President of the International Criminal Tribunal for the Prosecution of Persons Responsible for Genocide and Other Serious Violations of International Humanitarian Law Committed in the Territory of Rwanda and Rwandan Citizens Responsible for Genocide and Other Such Violations Committed in the Territory of Neighbouring States between 1 January and 31 December 1994 addressed to the President of the Security Council, U.N. Doc. S/2004/341, ๆ 6, 30 (May 3, 2004) (detailing the revised completion strategy of the ICTR); Completion Strategy of the International Criminal Tribunal for Rwanda, U.N. Doc. S/2003/946, Enclosure, September 29, 2003 (reducing the overall number of investigations for the ICTR); Report of the International Criminal Tribunal for the Prosecution of Persons Responsible for Genocide and Other Serious Violations of International Humanitarian Law Committed in the Territory of Rwanda and Rwandan Citizens Responsible for Genocide and Other Such Violations Committed in the Territory of Neighbouring States between 1 January and 31 December 1994, U.N. Doc. A/57/163.S/2002/733, If 9 (July 2, 2002) ("The Prosecutor has revised her future investigation programme from the originally estimated number of 136 new suspects and will now only conduct investigations against 14 new individuals together with 10 ongoing investigations."); ICTR Press Release, ICTR President Calls for Compensation for Victims, ICTR/INFO-9-2-326.EN (Oct. 31, 2002) (same). 
courts in the Balkans ${ }^{71}$ and Rwanda. ${ }^{72}$ In addition, Tribunal prosecutors began to make a concerted effort to dispose of their cases by means of guilty pleas. Initially, at the ICTY, these efforts proved remarkably successful: eight of the record fifteen defendants convicted at the ICTY in 2003 convicted themselves. ${ }^{73}$ Only one ICTY defendant

71. Both Tribunals added a provision to their procedural rules, permitting them to transfer their cases to national courts for prosecution. See ICTR Press Briefing, ICTR/INFO-9-13-22.EN (July 8, 2002), available at http://www.ictr/org/wwwroot/ENGLISH/pressbrief/2002/brief9-1322.btm (describing new Rule 11 bis); 1CTY Press Release, Extraordinary Plenary Session of 30 September 2002, U.N. Doc. JDH/PIS/696e (Oct. 1, 2002), available at http://www.un.org/icty/ pressrel/p696-e.htm (same); ICTY 2002 Annual Report, supra note 70, If 42; ICTY Press Release, Address by his Excellency, Judge Claude Jorda, President of the International Criminal Tribunal for the Former Yugoslavia, to tbe United Nations Security Council, U.N. Doc. JDH/P.I.S./690-e (July 26, 2002), available at http://www.un.org/icty/pressreal/p690-e.htm; see also Mark A. Drumbl, Looking Up, Down and Across: The ICTY's Place in the International Legal Order, 37 NEW ENGLAND L. REV. 701 (2003) (describing the plan to transfer defendants to Bosnian courts). The ICTY prosecution has recently sought permission from the Trial Chambers to transfer some cases to the courts of Bosnia, Croatia, and Serhia. See, e.g., Prosecutor v. Stanković, Case No. IT96-23/2-PT, Decision on Referral of Case Under Rule 11 bis (May 17, 2005); Prosecutor v. Janković, Case No. 1T-96-23/2-PT, Decision on Referral of Case Under Rule 11 bis (July 22, 2005); Prosecutor v. Kovacević, Case No. IT-01-42/2-I, Order on the Prosecutor's Request for Referral to NJational Authorities Under Rule 11 bis (Jan. 20, 2005); Prosecutor v. Ademi \& Norac, Case No. IT-04-78-PT, Order for Further Information in the Context of the Prosecutor's Request under Rule 11 bis (Jan. 20, 2005).

72. The ICTR has already transferred the twenty-five case files to Rwanda. See Rwanda: UN Tribunal Hands More Cases to National Authorities, IRINNEws.oRG, July 27, 2005, http://www.irinnews.org/report.asp?ReportID $=48321$ \&SelectRegion=Great_Lakes\&SelectCountr y=RWANDA (last visited Jan. 31, 2006); see also Letter dated 30 April 2004 from the President of tbe International Criminal Tribunal for the Prosecution of Persons Responsible for Genocide and Other Serious Violations of International Humanitarian Law Committed in the Territory of Rwanda and Rwandan Citizens Responsible for Genocide and Otber Such Violations Committed in the Territory of Neighbouring States between 1 January and 31 December 1994 addressed to the President of the Security Council, U.N. Doc. S/2004/341, IT 36-38 (May 3, 2004) (reporting that the ICTR prosecutor intends to transfer forty-one cases in total); International Bar Association, Rwanda: Government to Take Over More War Crimes Prosecutions, LEGAL BRIEF AFrICA, Mar. 14, 2005; Completion Strategy of the International Criminal Tribunal for Rwanda, U.N. Doc. S/2003/946, Enclosure at ๆ 23 (Sept. 29, 2003); ICTR NEwSLETTER, June 2004, at 5 ("The Prosecutor has identified 41 cases which he intends to transfer to Rwanda and other national jurisdictions for adjudication."); UN War Crimes Court Close to Deal with Rwanda on Transferring Cases, AGEnCE France-Presse, Aug. 13, 2004.

73. The four trials that the ICTY did conduct led to the conviction of seven defendants. See Prosecutor v. Simić et al., Case No. IT-95-9-T, Judgment (Oct. 17, 2003) (Blagoje Simić, Miroslav Tadić, and Simo Zarić); Prosecutor v. Stakić, Case No. IT-97-24-T, Judgment (July 31, 2003) (Milomir Stakić); Prosecutor v. Naletilić \& Martinović, Case No. IT-98-34-T, Judgment (Mar. 31, 2003) (Mladen Naletilić and Vinko Martinović); Prosecutor v. Galić, Case No. IT-98-29-T, Judgment (Dec. 5, 2003) (Stanislav Galić). In addition, guilty pleas were tendered by eight others: Predrag Banović, Prosecutor v. Meakić et al., Case No. IT-02-65-PT, Joint Motion for the Consideration of a Plea Agreement Between Predrag Banovic and the Office of the Prosecutor, Annex 1 (June 18, 2003) [hereinafter Banović Plea Agreement]; Momir Nikolić, Prosecutor v. Momir Nikolić, Case No. IT-02-60.PT, Joint Motion for Consideration of Plea Agreement Between Momir Nikolić and the Office of the Prosecutor, Annex A, Amended Plea Agreement (May 7, 2003) [hereinafter Momir Nikolić Plea Agreement]; Dragan Obrenović, Prosecutor v. Dragan Obrenović, Case No. IT-02-60-PT, Joint Motion for Consideration of Plea Agreement 
has pled guilty since January $2004,{ }^{74}$ however, and the proliferation of guilty pleas in 2003 and their abrupt drop-off in 2004 appear directly related to the sentencing practices of the ICTY Trial Chambers in guilty-plea cases. More particularly, ICTY defendants were willing to plead guilty when they were able to bargain for and receive relatively lenient sentences in exchange for their guilty pleas. But they stopped pleading guilty when they lost confidence that they would be sentenced in accordance with the bargains that they had negotiated.

In most guilty-plea cases, the ICTY prosecution and defense agree on a sentence or a narrow range of sentences to recommend to the Trial Chamber. As the following Sections will reveal, before December 2003, this method of plea bargaining proved an effective means of inducing defendants to plead guilty because the Trial Chambers had never imposed a sentence longer than that which the prosecution recommended. Sentencing in accordance with prosecutorial recommendations proved uncontroversial because, in the early days of ICTY sentence bargaining, prosecutors offered only modest concessions to defendants pleading guilty; they were so modest in fact that, in some cases, it was not clear that there existed any sentencing differential between a conviction after trial and a conviction after a guilty plea. In contrast, the sentence recommendations negotiated more recently have been far more lenient. They have been so lenient, in fact, that some Trial Chambers have refused to sentence in accordance with them. The following Sections will detail the ICTY's early guilty pleas, the evolution that has taken place both in the prosecution's efforts to obtain guilty pleas and the Trial Chambers' response to those efforts, and the chilling effect of the Trial Chambers' sentencing on the willingness of ICTY defendants to plead guilty.

\section{A. The ICTY's Early Guilty Pleas: Limited Benefits for Defendants}

The first two ICTY defendants to enter guilty pleas did so without engaging in plea bargaining. The first defendant to plead

Between Dragan Obrenović and the Office of the Prosecutor, Annex A, Plea Agreement (May 20, 2003) [hereinafter Obrenović Plea Agreement]; Dragan Nikolić, Prosecutor v. Dragan Nikolić, Case No. IT.94-2-S, Sentencing Judgment, If 35 (Dec. 18, 2003) [hereinafter Dragan Nikolić Sentencing Judgment]; Darko Mrđa, Prosecutor v. Mrđa, Case No. IT-02-59-S, Sentencing Judgment, If 4 (Mar. 31, 2004) [hereinafter Mrđa Sentencing Judgment], Miodrag Jokić, Prosecutor v. Jokić, Case No. IT-01-42/1-S, Sentencing Judgment, ๆף 7-11 (Mar. 18, 2004) [hereinafter Jokić Sentencing Judgment]; Miroslav Deronjić, Prosecutor v. Deronjić, Case No. IT02-61-PT, Plea Agreement (Sept. 29, 2003) [hereinafter Deronjić Plea Agreement]; and Ranko Češić, Prosecutor v. Češić, Case No. 95-10/1-PT, Plea Agreement (Oct. 8, 2003) [hereinafter Češić Plea Agreement].

74. Miroslav Bralo pled guilty in July 2005. Prosecutor v. Bralo, Case No. IT-95-17-PT, Plea Agreement, T 9 (July 18, 2005). 
guilty, Dražen Erdemović, was a foot soldier in the Bosnian Serb army who participated in the Bosnian Serbs' July 1995 massacre of approximately 7,000 Bosnian Muslims at Srebrenica. Erdemović brought himself and his crimes to the attention of the ICTY in 1996 and immediately pled guilty to crimes against humanity without any offer of leniency. ${ }^{75}$ Goran Jelisić, the next ICTY defendant to plead guilty, proffered his guilty plea over the objections of his lawyers and received no concessions therefor. ${ }^{76}$ Stevan Todorović pled guilty in December 2000 , and his case was seemingly the first to feature sentence bargaining. As a consequence of this bargaining, Todorović did obtain what seemed at the time to be substantial sentencing concessions, but the bestowal of these concessions can be explained, at least in part, by the unusual circumstances surrounding his arrest. Todorovic was appointed Police Chief of Bosanski Šamac during the Bosnian conflict, and as such, he participated in the take-over of the municipality and in the deportation and detention of the non-Serb population. ${ }^{77}$ After he was indicted, Todorović was allegedly arrested by means of kidnapping and delivered to NATO forces in Bosnia-Herzegovina ("SFOR"). ${ }^{78} \mathrm{He}$ consequently challenged the legality of his arrest, and, in doing so, obtained an order from the Trial Chamber requiring SFOR and the States participating in SFOR to provide Todorovic with wide-ranging and potentially embarrassing information about his arrest. ${ }^{79}$ NATO and the United States, among other States, vehemently objected to the order; thus, it did not come as a particular surprise when the prosecution offered Todorović a generous sentencing recommendation to

75. Prosecutor v. Erdemović, Case No. IT-96-22-T, Sentencing Judgment, ๆף 3, 6, 10 (Nov. 29, 1996) [hereinafter Erdemović Sentencing Judgment]. For a thorough discussion of the Erdemović case, see Combs, supra note 56, at 109-14.

76. See Combs, supra note 56, at 117. For a thorough discussion of the Jelisić case, see $i d$. at 115-17.

77. Prosecutor v. Todorović, Case No. IT-95-9/1, Sentencing Judgment, ๆ $35,42,45$ (July $31,2001)$ [hereinafter Todorović Sentencing Judgment].

78. See Major Christopher M. Supernor, International Bounty Hunters for War Criminals: Privatizing the Enforcement of Justice, 50 A.F.L. REV. 215, 217 n.11 (2001); Marlise Simmons, War Crimes Court Takes It Easy on a Cooperative Bosnian Serb, N.Y. TIMES, Aug. 1, 2001, at A4 (reporting that the method of Todorovic's arrest set his case apart from others and was a difficult issue for the court to handle). A regional court in Serbia subsequently convicted nine people of "kidnapping for money." 9 Convicted of Kidnap of War-Crimes Suspect, N.Y. TIMES, Dec. 12, 2000, at A15; see also Prosecutor v. Todorović, Case No. IT-95-9/1, Transcript at 786 (Dec. 13, 2000) (detailing the defense counsel's discussion of Todorović's capture and his captors' subsequent prosecution).

79. Sean D. Murphy, Contemporary Practice of the United States Relating To International Law, 95 AM. J. INT'L L. 387, 401 (2001). 
secure both his guilty plea and the withdrawal of his troublesome challenge to his arrest. 80

The prosecution's recommended sentences for the next four defendants to plead guilty, by contrast, did not seem significantly lower than the sentences which likely would have been imposed after trials. In the Sikirica case, for instance, the defendants were Duško Sikirica, Commander of Security at the infamous Keraterm prison camp, and Damir Došen and Dragen Kolundžija, two of Keraterm's shift commanders. ${ }^{81}$ Keraterm detainees were kept in appalling conditions and were regularly beaten and killed by guards and by outsiders given entry by guards. ${ }^{82}$ After the trial was mostly completed, all three defendants pled guilty to persecution as a crime against humanity, admitting to varying levels of culpability. The persecution count alleged persecution by five methods: (a) murder; (b) torture and beating; (c) sexual assault and rape; (d) harassment, humiliation, and psychological abuse; and (e) confinement in inhumane conditions. ${ }^{83}$ Sikirica acknowledged participating in all of those methods and admitted to personally killing one detainee; 84 Došen admitted to participating in (b), (d), and (e);85 and Kolundžija admitted only to (e). ${ }^{86}$ Pursuant to the plea agreement, the prosecution recommended sentences of between ten and seventeen years' imprisonment for

80. Todorović pled guilty to one count of persecution as a crime against humanity for murdering one person, beating twelve others, ordering and participating in the unlawful detention of non-Serb civilians, ordering subordinates to torture and interrogate detainees, and ordering six men to perform fellatio on one another on three different occasions. Todorović Sentencing Judgment, supra note 77, 9 9. In Todorović's plea agreement, the prosecution and defense each agreed to recommend sentences of between five and twelve years' imprisonment. Id. I 11. The prosecution recommended a twelve year sentence, and the Trial Chamber sentenced him to ten years' imprisonment. Id. I 115. At Todorović's sentencing hearing, the prosecution opined that, had Todorovic been convicted at trial, he probably would have been sentenced to a term of imprisonment ranging from fifteen to twenty-five years or more. Prosecutor v. Todorović, Case No. 1T-95-9/1, Transcript at 55 (May 4, 2001) (on file with author).

81. Prosecutor v. Sikirica et al., Case No. IT-95-8-T, Sentencing Judgment, $1 \uparrow 118,153,200$ (Nov. 13, 2001) [hereinafter Sikirica Sentencing Judgment].

82. See id. II 56-57, 62-65, 66-83 (describing conditions in the Keraterm camp); Prosecutor v. Tadić, Case No. IT-94-1-T, Opinion and Judgment, ๆ 159 (May 7, 1997); Prosecutor v. Banović, Case No. IT-02-65-1-S, Sentencing Judgment, If 27 (Oct. 28, 2003) [hereinafter Banović Sentencing Judgment] ("Keraterm authorities, as well as 'visitors', regularly subjected the detainees to severe beatings and cruel and humiliating treatment, and many were killed.").

83. Sikirica Sentencing Judgment, supra note 81, \18.

84. Id. ๆๆ $18,21$.

85. Id. ๆ 26.

86. Id. ๆ 32. 
Sikirica, between five and seven years' imprisonment for Došen, and between three and five years' imprisonment for Kolundžija. ${ }^{87}$

Since the Sikirica guilty pleas did not occur until the trial was nearly completed, the prosecution did not save much time or resources through the guilty pleas, and one can presume that the prosecution consequently was not willing to offer as generous concessions to the Sikirica defendants as it would have to defendants who pled guilty before the trial began. That said, the Sikirica bargain is nonetheless notable in how little it seemed to provide the defendants. Although some of the relevant circumstances were different, ${ }^{88}$ the ICTY had earlier sentenced Zlatko Aleksovski, a Croatian prison camp commander, to a mere two-and-one-half-year prison sentence after trial, ${ }^{89}$ which the Appeals Chamber subsequently increased to seven years' imprisonment. ${ }^{90}$ As another example, Hazim Delić, Deputy Commander of the Čelebici prison camp, was convicted of brutally murdering two detainees, raping and torturing two more, and torturing numerous others, some by means of an electric shock device. ${ }^{91}$ Delić received a sentence of twenty years' imprisonment after trial, ${ }^{92}$ which was reduced after appeal to eighteen years' imprisonment; ${ }^{93}$ that is, after a full-blown trial, Delić received a sentence only slightly higher than the prosecution's maximum recommendation for Sikirica, for crimes apparently involving greater harm. Similarly, Dragoljub Prcac was an administrative aide at the notorious Omarska camp. ${ }^{94}$ Prcac, like Kolundžija, held a position of authority in a brutal detention center but was not convicted of inflicting any direct harm. ${ }^{95}$ Without pleading guilty, Prcac was sentenced to five years' imprisonment; 96 that is, Prcac received a sentence at the upper end of the prosecution's sentencing recommendation for Kolundžija.

87. Id. If $25,31,37$. The prosecution recommended the maximum sentence for each defendant. Id. I 42; Prosecutor v. Sikirica, Case No. IT-95-8.T, Transcript at 5687 (Oct. 8, 2001) (on file with author).

88. Among other things, the conditions prevailing in the Keraterm camp seemed to be worse than those at the Kaonik prison, at which Aleksovski was a commander. See generally Prosecutor v. Aleksovski, Case No. IT-95-14/1-A, Judgment (Mar. 24, 2000).

89. Id. If 244.

90. Id. If 191.

91. Prosecutor v. Delalić, Case No. IT-96-21-A, Judgment, ๆ 1253 (Feb. 20, 2001).

92. Id. ๆ 3.

93. Prosecutor v. Mucić, Case No. IT-96-21-Tbis-R117, Sentencing Judgment, If 44 (Oct. 9, 2001).

94. Prosecutor v. Kvoćka, Case No. IT-98-30/1-T, Judgment, fl 439 (Nov. 2, 2001).

95. The prosecution accused Prcac of personal involvement in certain brutalities but failed to prove its allegations. Id. II 451-463.

96. Id. ๆ 726 . 
The next guilty plea to be entered at the ICTY was tendered in May 2002 by Milan Simić. Simić pled guilty to two counts of torture as a crime against humanity for encouraging and participating in the beatings of five men. ${ }^{97}$ Simić had been indicted with four co-defendants, one of whom was Stevan Todorović.98 After Todorović pled guilty, a trial commenced against the remaining four co-defendants, and Simić pled guilty eight months after the trial began. In exchange for Simić's guilty plea, the prosecution agreed to recommend a sentence of no longer than five years' imprisonment. More importantly, it also agreed to withdraw several counts, including the most serious-persecution as a crime against humanity relating to Simićs mayor-like role in the town of Bosanski Šamać. ${ }^{99}$ While functioning in that capacity, Simić had been accused of implementing orders and regulations that unlawfully detained non-Serb civilians in inhumane conditions. ${ }^{100}$ Although prosecutors believed that substantial evidence supported that charge, its continued prosecution was undesirable because Simić, a paraplegic, had grave health issues which had considerably slowed the trial. ${ }^{101}$ The prosecution withdrew the count, then, largely due to its desire to speed up the trial by removing the illness-prone Simić. In accordance with the prosecution's recommendation, the Trial Chamber sentenced Simić to five years' imprisonment. ${ }^{102}$ The sentence did not seem particularly discounted given that the crimes to which Simic pled guilty-crimes which involved the beating of five men-involved less harm than is the norm for ICTY crimes. Yet such a sentence would

97. Prosecutor v. Milan Simić, Case No. IT-95-9/2-S, Sentencing Judgment, भा 9-11, (Oct. 17, 2002) [hereinafter Simić Sentencing Judgment].

98. Prosecution v. Blagoje Simić et al., Case No. IT-95-9, Second Amended Indictment (Dec. 11, 1998)

99. Simić Sentencing Judgment, supra note 97, ๆ $10,13,22$.

100. See Prosecutor v. Simić et al., Case No. IT-95-9, Fourth Amended Indictment, If 16 (Jan. 9, 2002) (setting forth the persecution charge).

101. Interview with BH in Sarajevo, Bosnia-Herzegovina (Dec. 5, 2003). Simić's medical condition complicated the conduct of the trial from the outset. In an assassination attempt, Simic had lost the use of both legs, most of the use of one arm, and a kidney, which left him prone to a variety of imfections. Simić cannot move a wheelchair without assistance and, because he cannot move the upper part of his body while in bed, he suffers continually from bed sores. Telephone Interview with Slobodan Zecević, ICTY Defense Counsel (Dec. 17, 2002). At first, the Trial Chamber held sessions only in the mornings to accommodate Simic's medical needs; later, the Tribunal provided him with a suitable bed on which to rest during breaks and a nurse to assist him, allowing the Trial Chamber to sit for an additional hour in the afternoon. Finally, in February 2002, the Tribunal installed a video-link and a two-way telephone link between the ICTY's Detention Unit and the courtroom, so that Simić could remain in the Detention Unit while still monitoring the trial and communicating with his counsel. Simić Sentencing Judgment, supra note 97, I| 7-8.

102. Simić Sentencing Judgment, supra note $97, \uparrow 122$. 
have been unthinkable had the factual basis for Simić's conviction encompassed all the conduct for which he was initially charged.

During the first nine years of the ICTY's existence, then, only seven defendants pled guilty. Two of those defendants-Erdemovic and Jelisic - did not negotiate with the prosecution for a reduced sentence. The remaining five did, but only two of them-Todorovic and Simic-appeared to receive considerable sentencing benefits in exchange for their guilty pleas. Prosecutors appeared willing to bestow these benefits on Todorović and Simić, however, primarily because unusual features of their cases made prosecutors particularly keen to dispose of them summarily. Prosecutors were not inclined to offer generous sentencing discounts to run-of-the-mill defendants, and, as a consequence, those defendants were not inclined to enter guilty pleas. By October 2002, when the next ICTY defendant to plead guilty did so, however, the Security Council's pressure on the Tribunal to complete its work had made the expeditious disposition of cases a necessity. In addition, evidentiary weaknesses in the cases against certain high-ranking defendants had made the information possessed by lower-ranking defendants particularly valuable. Consequently, in 2002 and 2003, the prosecution engaged in vigorous efforts to induce defendants both to plead guilty and to provide the prosecution with information useful in other cases. Initially, these efforts were extremely successful. The following Section will discuss the spate of ICTY guilty pleas that were tendered in 2002 and 2003 and the sentencing backlash to which those cases gave rise.

\section{B. The Second Phase in ICTY Plea Bargaining: Generous Concessions, Substantial Cooperation, and Judicial Displeasure}

Biljana Plavšić had been co-President of the Serbian Republic of Bosnia and Herzegovina and was instrumental in promoting and implementing the Bosnian Serbs' ethnic-cleansing campaign, which resulted in the expulsion and death of hundreds of thousands of Bosnian Muslims and Croats. ${ }^{103}$ In October 2002, Plavšić pled guilty to persecution as a crime against humanity, and the prosecution

103. Approximately 850 Muslim and Croat-occupied villages were destroyed entirely, and in many municipalities, virtually all non-Serbs were killed or forced to flee. Prosecutor v. Plavšić, Case No. IT-00-39 \& 40/1, Sentencing Judgment, If 32 (Feb. 27, 2003) [hereinafter Plavšić Sentencing Judgment]. In the thirty-seven municipalities described in Plavšićs indictnıent, the evidence showed that Serbian forces killed approximately 50,000 non-Serbs, destroyed more than 100 mosques and Catholic churches, and established more than 400 detention facilities, which confined nearly 100,000 people. Id. ๆT 41, 44, 45-48; Prosecutor v. Plavšić, Case No. IT-00-39 \& 40/1-S, Transcript of Sentencing Hearing, at 416 (Dec. 16, 2002). 
withdrew genocide charges that had been brought against her. ${ }^{104}$ The prosecution recommended a sentence of between fifteen and twentyfive years' imprisonment for Plavšic, ${ }^{105}$ and the Trial Chamber sentenced her to a mere eleven years in prison. ${ }^{106}$

Nine guilty pleas followed Plavšić's in quick succession, ${ }^{107}$ and many featured lenient-some would argue, unseemly-sentence recommendations, particularly in comparison to previous ICTY cases,

104. Plavšić Sentencing Judgment, supra note 103 , ๆ 5.

105. Prosecutor v. Plavšić, Case No. IT-00-39 \& 40/1-S, Transcript of Sentencing Hearing at 638 (Dec. 18, 2002). The prosecution Iauded PIavšić's guilty plea as "an unprecedented contribution to the establishment of truth and a significant effort toward the advancement of reconciliation." Prosecution v. PIavšić, Case No. IT-00-39 \& 40/1-S, Prosecution's Brief on the Sentencing, If 25 (Nov. 25, 2002) (on file with author). At Plavšić's sentencing hearing, the prosecution presented the testimony of a number of witnesses, including former United States Secretary of State Madeleine Albright and Deputy Chairperson of the South African Truth and Reconciliation Commission, Dr. Alex Boraine, who praised Plavšić's guilty plea for the contribution it made to reconciliation in Bosnia. Prosecutor v. Plavšić, Case No. IT-00-39 \& 40/1S, Transcript of Sentencing Hearing, at 520-22, 592-96 (Dec. 17, 2002); see also Prosecutor v. Plavšić, Case No. IT-00.39 \& 40/1-S, Transcript of Sentencing Hearing, at 408 (Dec. 16, 2002) (Witness Mirsad Tokaca described Plavšić's guilty plea as "an extremely courageous, brave, and important gesture," saying, "[I]t represents support to what is the ultimate aim of all of us ... [that] normal conditions of life should be resumed in Bosnia-Herzegovina, not only in BosniaHerzegovina but in the entire region as well."); id. at 458-59 (Elie Wiesel praising Plavšic as "the only accused to have freely and wholly assumed her role in the wrongdoings and crimes set out in the indictment, even though she once moved in the highest circles of power in her country.").

106. Plavšić Sentencing Judgment, supra note 103, I 134. The sentence horrified Bosnian Muslims. Mujesira Memisević, whose husband and children were killed during a Bosnian Serb ethnic-cleansing campaign, described the sentence as "outrageously low" and stated, "I am speechless. I cannot talk at all. I am shivering. I am completely shaken." Daria Sito-Sucic, Muslim Victims Outraged, Say Plavšić Sentence Low, REUTERS, Feb. 27, 2003. The Bosnian president of the federal committee for the missing, Amor Masović, observed that Plavšić will spend just two and a half minutes in prison for every one of her 200,000 Bosniak and Croat victims. Amra Kebo, Regional Report: Plavšić Sentence Divides Bosnia, IWPR's TRIBUNAL UPDATE, No. 302, Feb. 24-28, 2003. And the ICTY's President enraged victims further by sending Plavšic to serve her sentence in Sweden, where she is housed in a minimum-security prison that apparently features sauna, solarium, massage room, horse-riding paddock, and other amenities. Patrick McLoughlin, Serb War Criminal Plavšić Goes to Swedish Jail, ReUTERS, June 27, 2003; see also Patrick McLoughlin, War Criminal's Conditions Rile Guards, REUTERS, Aug. 1, 2003 (Swedish prison guards objecting when Plavšić was granted special privileges including private accommodation with a toilet and extended recreation time, and when she was presented a birthday cake on her birthday). By contrast, Plavšić has claimed that, in an effort to coerce her to testify against Slobodan Miloševic, "bad air from a nearby factory is being pumped into her cell, causing her lungs to bleed." Serb Leader Alleges Prison Conspiracy, THE IndePEndent (London), Oct. 18, 2003; Former Bosnian Serb President Complains about Prison Conditions in Sweden, AGENCE FrANCE-PRESSE, Oct. 17, 2003.

107. See Banović Plea Agreement, supra note 73; Momir Nikolić Plea Agreement, supra note 73; Obrenović Plea Agreement, supra note 73; Dragan Nikolić Sentencing Judgment, supra note 73, If 35; Mrda Sentencing Judgment, supra note 73, ๆ 4; Jokić Sentencing Judgment, supra note 73, ๆ 7-11; Deronjić Plea Agreement, supra note 73; Češić Plea Agreement, supra note 73; Prosecutor v. Babić, Case No. IT-03-72-I, Annex A to the Joint Motion for Consideration of Plea Agreement between Milan Babić and the Office of the Prosecutor Plea Agreement (Jan. 22, 2004). 
even previous cases involving guilty pleas. Ranko Češić, for instance, was a member of the Bosnian Serb Police Reserve Unit at the Brčko Police Station and was tasked with, among other things, arresting specified non-Serbs and bringing them to the Brčko Police Station or to the Luka Prison Camp. ${ }^{108}$ The Luka Prison Camp was the camp at which Goran Jelisić-the second ICTY defendant to plead guiltyacted as de facto commander. Češić admitted to killing ten people and to forcing two brothers to perform fellatio on one another; ${ }^{109}$ that is, he admitted to crimes roughly comparable to the thirteen murders that Jelisic admitted when he pled guilty. Both men pled guilty, but Jelisić's plea, coming before the rush to close the Tribunal, gained him nothing. The prosecution recommended a life sentence for Jelisić, ${ }^{110}$ and the Trial Chamber imposed a near equivalent, sentencing him to forty years in prison. ${ }^{111}$ By contrast, in the plea agreement it concluded with Češić, the prosecution promised to recommend a sentence of between thirteen and eighteen years' imprisonment, ${ }^{112}$ and the Trial Chamber sentenced him to an eighteen year term. ${ }^{113}$ Češić held a less senior position than Jelisić, and, unlike Jelisić, Češić did agree to provide information to the prosecution, ${ }^{114}$ but the prosecution gave no indication that it found Češićs information particularly useful. ${ }^{115}$ Even if it had, it is doubtful that Cešić's provision of that

108. Prosecutor v. Češić, Case No. IT-95-10/1-S, Sentencing Judgment, II 7 (Mar, 11, 2004) [hereinafter Češić Sentencing Judgment].

109. Id. ๆๆ 9-17.

110. Prosecutor v. Jelisić, Case No. IT-95-10-T, Judgment, II 119 (Dec. 14, 1999) [hereinafter Jelisić Judgment]; Prosecution v. Jelisić, Case No. IT-95-10-T, Transcript at 3070, 3132 (Nov. 25, 1999). The prosecution's harsh sentencing recommendation likely stemmed in part from the fact that Jelisic's guilty plea did not save the Tribunal time and resources because Jelisić pled guilty only to the crimes against humanity and war crimes charges, but not to a genocide count. So, despite Jelisić's guilty plea, a trial had to be held on that count. After hearing the prosecution's evidence, the Trial Chamber acquitted Jelisić of genocide, holding that the prosecution had not proved beyond a reasonable doubt that "genocide was committed in Brčko during the period covered in the indictment." It held in addition that although Jelisić "obviously singled out Muslims, he killed arbitrarily rather than with the clear intention to destroy a group." Jelisić Judgment, supra, ๆ 108.

111. Jelisić Judgment, supra note 110, ๆ 139.

112. Češić Plea Agreement, supra note 73, ๆ 11.

113. Češić Sentencing Judgment, supra note 108, ๆ 111.

114. Češić Plea Agreement, supra note 73, ๆ 10.

115. In many guilty-plea cases at the ICTY, the prosecution highlights to the Trial Chamber the substantial value of the defendant's cooperation. In Erdemović, for instance, the prosecution described the defendant's cooperation as "substantial, full and comprebensive" and in particular noted that Erdemovic had provided the prosecution with facts of which they had previously been unaware, enabling them to initiate on-site investigations that confirmed Erdemović's statements. Prosecutor v. Erdemović, Case No. IT-96-22-T, Sentencing Judgment, I 16(iv) (Mar. 5, 1998). Similarly, in Babić, the prosecution's sentencing brief went on for pages describing the usefulness of Babić's information and testimony. Prosecution v. Babić, Case No. IT-03-72-S, 
information and his subordinate position to Jelisic would justify the vast difference between the two men's sentences.

Other examples of sentencing disparities abound. Predrag Banović, a guard at the same Keraterm Camp where Sikirica, Došen, and Kolundžija committed their crimes, pled guilty in June 2003 to helping beat five prisoners to death and participating in twenty-seven other beatings and shootings. 116 Even after Sikirica pled guilty, the prosecution recommended that he receive a seventeen year sentence for committing only one murder, while it recommended that Došen receive a seven year sentence when he was not personally implicated in any serious violence. ${ }^{117}$ Concededly, Sikirica and Došen held positions of greater responsibility than did Banović, but Banović's crimes were vastly more numerous and brutal; thus, one might have expected prosecutors to recommend for Banović a sentence far greater than Došen's and perhaps equal to Sikirica's, particularly since Došen and Sikirica also pled guilty. Instead, in exchange for Banović's guilty plea, the prosecution and defense agreed to recommend a mere eight year term of imprisonment, which the Trial Chamber duly imposed.118 Again, Banović's plea agreement required him to cooperate with the prosecution, 119 an obligation not imposed on the Sikirica defendants. But this factor cannot explain the sentencing differential between the two cases because the Banović prosecutor told the Trial Chamber that Banović's cooperation had not been sufficient to treat it as a mitigating factor. ${ }^{120}$ The relative leniency of Banović's eight year sentence is further highlighted when it is compared to the twenty year sentence that the ICTY contemporaneously imposed after a trial on

Prosecution's Sentencing Brief, ๆ $37-46$ (Mar. 22, 2004). The prosecution's sentencing brief in Češić, by contrast, states only that Češić had engaged in an interview with the prosecution during which he shared his knowledge of the international crimes that took place in and around Brčko during the armed conflict in Bosnia and that he had agreed to testify in future proceedings if asked to do so. Prosecutor v. Češić, Case No. 95-10/1-S, Prosecution's Sentencing Brief, If 57 (No $\therefore$ 12, 2003).

116. Banović Sentencing Judgment, supra note 82, at 29-30; Prosecutor v. Banović, Case No, IT-02-65/1-S, Transcript of Sentencing Hearing, I 104 (Sept. 3, 2003); see also Bosnian Serb Camp Suspect Pleads Guilty at Hague, REUTERs, June 26, 2003 (discussing the beatings and guilty plea).

117. Sikirica Sentencing Judgment, supra note 29, ๆ 25, 31, 42.

118. Banović Sentencing Judgment, supra note 82, ๆ 96.

119. Prosecutor v. Banović, Case No. IT-02-65-PT, Annex 2 to Plea Agreement (June 2, 2003).

120. Prosecutor v. Banović, Case No. IT-02-65/1-S, Transcript of Sentencing Hearing at 116 (Sept. 3, 2003). 
Mitar Vasiljević, who, like Banović, participated in the killing of five people. ${ }^{121}$

Prosecutorial sentence recommendations became so lenient in 2003 that they began to lose their influence over the Trial Chambers. ICTY Trial Chambers imposed sentences at or below prosecutorial recommendations for the first nine defendants who pled guilty, ${ }^{122}$ but in December 2003, the Trial Chamber rejected the prosecution's recommendation of a fifteen-to-twenty year sentence in the Momir Nikolić case and instead sentenced Nikolić to a twenty-seven year term. ${ }^{123}$ In sentencing outside the prosecution's recommended range, the Trial Chamber emphasized that Nikolić was evasive when testifying in the trial of his co-defendants. ${ }^{124}$ Eight days later, the same Trial Chamber sentenced Momir Nikolić's co-defendant, Dragan

121. Prosecutor v. Vasiljević, Case No. IT-98-32-T, Judgment, ๆ $96-111$ (Nov. 29, 2002). Vasiljevic participated in the so-called Drina River incident in which Serbian paramilitaries, among others, brought seven Bosnian Muslim men to the bank of the Drina river and shot them at close range, killing five of them. Id. I 97.

122. In the first round of sentencing in Erdemovic, the prosecution recommended a sentence not exceeding ten years. Erdemović Sentencing Judgment, supra note 75 . The Trial Chamber sentenced Erdemović to ten years' imprisonment. Id. In the second round of sentencing, the parties agreed in a plea agreement "that seven years' imprisonment would be an appropriate sentence." Prosecutor v. Erdemović, Case No. IT-96-22-T bis, Sentencing Judgment, ๆ 18(d) (Mar. 5, 1998). But the Trial Chamber sentenced Erdemović to five years' imprisonment. Id. If 23. In Jelisić, the prosecution asked for a sentence of life imprisonment. Jelisić Judgment, supra note 110, If 119. The Trial Chamber sentenced Jelisić to forty years' imprisonment. Id. I 139. In Todorovic, the parties entered into a plea agreement prohibiting the prosecution from recommending a sentence in excess of twelve years' imprisonment. Todorovic Sentencing Judgment, supra note 77 , I 11 . The prosecution recommended a sentence of twelve years' imprisonment, $i d$. ๆ 22, and the Trial Chamber sentenced Todorović to ten years' imprisonment, id. If 115. In Sikirica, as discussed above, the parties entered into plea agreements in which the prosecution agreed not to recommend sentences exceeding seventeen years', seven years', and five years' imprisonment for Sikirica, Došen, and Kolundžija, respectively. Sikirica Sentencing Judgment, supra note 29 , ๆ $25,31,37$. The prosecution recommended the maximum sentences for each defendant, id. \ 42 , and the Trial Chamber sentenced Sikirica, Došen, and Kolundžija to fifteen years', five years', and three years' imprisonment, respectively, id. If 245 . In Milan Simić, the parties entered into a plea agreement in which they each agreed to recommend a sentence of imprisonment of not less than three years and not more than five years. Simic Sentencing Judgment, supra note 97, I 13 . The prosecution recommended a five year sentence, id. I 30 , and the Trial Chamber imposed a five year sentence, id. I 122. In Plavšić, the prosecution recommended a sentence of between fifteen and twenty-five years' imprisonment. Prosecutor v. Plavšić, Case No. IT-00-39 \& 40/1-S, Prosecution's Brief on the Sentencing of Biljana Plavšić, If 43 (Nov. 25, 2002). The Trial Chamber imposed an eleven year sentence. Plavšić Sentencing Judgment, supra note 103. Finally, in Banović, the prosecutor and defense both agreed to recommend an eight year sentence for Banović. Banović Sentencing Judgment, supra note 82, ๆ 11. The Trial Chamber obliged. Id. I 96.

123. Prosecutor v. Momir Nikolić, Case No. IT-02-60/1-S, Sentencing Judgment, ๆ 19,183 (Dec. 2, 2003).

124. Id. I 156. 
Obrenović, to seventeen years' imprisonment after his guilty plea, ${ }^{125}$ a sentence which was well within the prosecution's fifteen-to-twenty year recommendation. Thus, Momir Nikolić's sentence appeared to be an aberration resulting from Nikolić's perceived lack of candor.

After another eight days, however, a different ICTY Trial Chamber spurned the prosecution's sentence recommendation, this time in the case of Dragan Nikolic (no relation to Momir). In addition to serving as Commander of the brutal Sušica prison camp, where murders, beatings, and rapes occurred daily, Dragan Nikolić, admitted to personally beating nine men to death, torturing five more, and facilitating countless rapes. ${ }^{126}$ After months of intense negotiations, the prosecution and defense entered into a plea agreement in which the prosecution agreed to recommend a fifteen year sentence for Nikolić. However, the Trial Chamber sentenced Nikolić to twentythree years' imprisonment, holding that the "brutality, the number of crimes committed and the underlying intention to humiliate and degrade would render a sentence such as [the prosecution] recommended unjust." 127 The Trial Chamber tried to prevent this harsher-than-recommended sentence from dealing a death blow to the prosecution's attempts to obtain subsequent guilty pleas by expressly stating that Nikolić would have received a life sentence had he not pled guilty. ${ }^{128}$ As will be discussed below, however, it is by no means clear that the Trial Chamber's efforts succeeded.

As part of Milan Babićs January 2004 plea agreement, the prosecution recommended an eleven year sentence for Babić, ${ }^{129}$ but the Trial Chamber sentenced him to thirteen years' imprisonment; holding that a term of no more than eleven years "would not do justice."130 A couple of months earlier, the Deronjić Trial Chamber did sentence in accordance with the prosecution's recommendations in that case, imposing on Deronjic the ten year prison sentence that the prosecution recommended, but it did so over the vehement dissent of the presiding judge, Wolfgang Schomburg. Judge Schomburg concluded that Deronjic deserved a sentence of no less than twenty years' imprisonment ${ }^{131}$ because even on the facts presented by the

125. Prosecutor v. Obrenović, Case No. IT-02-60/2-S, Sentencing Judgment, ๆf 156 (Dec. 10, 2003)

126. Dragan Nikolić Sentencing Judgment, supra note 73, ๆ 56-60, 66-104.

127. Id. ๆ 281.

128. Id. ๆ 214.

129. Prosecutor v. Babić, Case No. IT-03-72-S, Sentencing Judgment, If 42 (June 29, 2004).

130. Id. ๆी 101-102.

131. Prosecutor v. Deronjic, Case No. IT-02-61-S, Dissenting Opinion of Judge Schomburg, I 2 (Mar. 30, 2004). 
prosecution-which Judge Schomburg believed were abridged as a result of a charge bargain ${ }^{132}$ _Deronjić was shown to be a highranking perpetrator who had committed "heinous and long planned crimes." 133

Milan Babić's guilty plea was tendered in January 2004approximately one month after the Momir Nikolić and Dragan Nikolić Trial Chambers imposed their longer-than-recommended sentences. Given these sentences, Babic might have decided not to plead guilty but for the fact that he had been cooperating with the prosecution for two years before he was indicted and, as his defense counsel put it, "[i]t was a fait accompli that he would be indicted and plead guilty."134 Eighteen months elapsed, however, before the Tribunal received its next guilty plea in the Miroslav Bralo case. Miroslav Bralo's plea agreement is unusual in that it does not contain any provisions relating to sentence recommendations and indeed states that "no promises or inducements have been made by the Prosecutor to induce Miroslav Bralo to enter this Agreement."135 Bralo, however, was a low-level offender whose case almost certainly would have been transferred to the Special War Crimes Court in Sarajevo had he not pled guilty. Many ICTY defendants have vehemently opposed the transfer of their cases to Bosnia, ${ }^{136}$ and the desire to avoid that fate likely motivated Bralo's plea.

Guilty pleas at the ICTY have thus dropped off markedly since their height in 2003. One factor contributing to the substantially decreased interest in guilty pleas is the highly critical publicity engendered by the guilty pleas of 2003 and their concomitant sentence discounts. Victims' groups and legal commentators have harshly condemned the lenient sentences imposed on, among others, Plavšić, Banovic, and Darko Mrda, the latter of whom pled guilty to participating in the executions of more than 200 Bosnian Muslims. ${ }^{137}$

132. Id. I 9.

133. Id. If 5 .

134. Prosecutor v. Babić, Case No. IT-03-72-A, Transcript of Appeals Proceedings at 34 (Apr. $25,2005)$.

135. Prosecutor v. Bralo, Case No. IT·95-17-PT, Plea Agreement, If 9 (July 18, 2005).

136. E.g., Prosecutor v. Janković, Case No. IT-96-23/2-PT, Decision on Referral of Case under Rule 11 bis, II 16 (July 22, 2005).

137. Mrđa Sentencing Judgment, supra note 73, II 1, 4. For a sampling of the critical commentary concerning lenient sentences, see Sito-Sucic, supra note 106; Kebo, supra note 106; Emir Suljagić \& Amra Kebo, Mrda Guilty Plea Sparks Anger, IWPR's TRIBUnAL UPDATE, No. 322, Aug. 1, 2003 (Mrđa's guilty plea "sparkeđ a row among survivors and missing persons organisations who believe the proposed sentence is too lenient for the crimes committed - and are outraged that, to date, the remains of many of those murdered have not been recovered."); Bosnian Women's Association Calls Serb Camp Guard Sentence "Insult," BBC WORLDWIDE MONITORING, Oct. 29, 2003 (reporting the view of Bosnian victims that Predrag Banović's eight 
The diminished interest in guilty pleas can also be traced in part to the March 2004 departure of the Tribunal's American Chief of Prosecutions, Michael Johnson, who was a strong supporter of plea bargaining and who facilitated many of the 2003 plea agreements. Some front-line ICTY prosecutors, by contrast, are rumored to be lessthan-favorably disposed to plea bargaining; indeed, counsel for Dragan Nikolić accused prosecutors of essentially reneging on Nikolić's plea agreement by submitting a sentencing brief that was not in keeping with the spirit of the agreement ${ }^{138}$ and by failing to seek a reduction of Nikolić's sentence on appeal. ${ }^{139}$ Nikolić's counsel pointedly observed that such practices "will be noted by those whose duty it is to advise on the issue of making a Plea Agreement with the Prosecutor."140

While these factors have played some role, the primary reason that the ICTY is no longer obtaining many guilty pleas is that, as a result of the sentences imposed on Momir Nikolić, Dragan Nikolić, and Milan Babić, ICTY defendants no longer have the requisite certainty that they will receive the sentencing discounts for which they bargained. Numerous interviews with defense counsel and prosecutors confirm that ICTY defendants share with defendants accused of domestic crimes in Western countries similar views about the undesirability of incarceration. Thus, when assessing their options, most ICTY defendants seek first and foremost to reduce the amount of time they must spend behind bars. For this reason, the ICTY defendants who have pled guilty recently did so only after their counsel had engaged in intense and protracted negotiations over the prosecution's sentence recommendation. That is, they pled guilty only because they felt confident that they would receive a substantial sentencing discount in exchange for their guilty plea. Based on the

year sentence constituted "shamefully small punishment"); Bosnian Muslims Protest "Shameful" War Crimes Sentence, Agence France-Presse, Oct. 29, 2003 (reporting on victims' outrage following the Banović sentence); Nerma Jelacić \& Chris Stephen, Anger at Short Sentence for Prison Killer, lWPR's TRIBUNAL UPDATE, No. 331, Nov. 1, 2003 (reporting victim outrage about Banović's sentence); see also Pleading Repentance, BALKAN RECONSTRUCTION REPORT, Feb. 2, 2004 (reporting on a right-wing Croatian politician who decried Milan Babićs plea bargain, saying " $[w]$ here is the justice in the fact that a person who is believed to have been one of the most notorious figures in the bloody events of the 1990s in this region can expect only 11 years of punishment?"); Milanka Saponja-Hadzić, Hague Deals Reduce Impact, IWPR'S TRIBUNAL UPDATE, No. 321, July 24, 2003.

138. See Prosecutor v. Dragan Nikolić, Case No. IT-94-2-A, Transcript of Sentencing Proceedings on Appeal at 23 (Nov. 29, 2004) (Nikolić's counsel asserted that the prosecution's sentencing brief was not one "that actually matched the nature of the spirit and agreement which I thought we had gone into the matter, and I was left with a sense of unease and profound disappointment.").

139. Prosecutor v. Dragan Nikolić, Case No. IT-94-2-A, Appellant's Brief in Reply to the Prosecution Respondent's Brief, II 5 (Aug. 24, 2004).

140. Id. 
Trial Chambers' past practice, the defendants counted on the prosecution's recommendation to define the outer limit of their incarceration exposure. Now that the recommendations no longer provide that certainty, ICTY defendants apparently prefer to take their chances on a trial. Miroslav Bralo was not likely to have the opportunity to take his chance on an ICTY trial since his case seemed destined for trial in Bosnia. Thus, Bralo saw fit to plead guilty despite the Trial Chambers' recent repudiation of prosecutorial sentencing recommendations. That his plea agreement does not even contain a promise of a prosecutorial sentence recommendation may well reflect Bralo's awareness of their limited influence.

While some Tribunal insiders maintain that prosecutors continue to pursue plea negotiations in some cases, all agree that the Trial Chambers' failure to sentence in accordance with prosecutorial recommendations has had a chilling effect on the bargaining. ${ }^{141}$ Milan Babić's defense counsel observed, for instance, that when he advised Babić to enter into the plea agreement, he "believed that a plea agreement meant something, that the Court would be guided by a plea agreement, that they would follow the recommendation." He learned subsequently, he said, that the effect of a plea agreement "is nothing." 142 As the following Part will reveal, ICTR prosecutors are also experiencing difficulty obtaining guilty pleas, but there the difficulty bears little relationship to the sentencing recommendations the prosecution is willing to make, or the sentences the Trial Chambers actually impose.

\section{The Role of Ideology in Plea Bargaining: Guilty Pleas at THE ICTR}

In April 1994, brutal ethnic violence erupted in Rwanda, a small country in the Great Lakes Region of Africa, whose population has historically been divided into two predominant groups, the Hutu and the Tutsi. ${ }^{143}$ The Tutsi minority had ruled Rwanda for

141. Telephone Interview with HN (Feb. 17, 2005); Interview with ME in The Hague, Netb. (Nov. 18, 2004); Telephone Interview with Howard Morrison, ICTY Defense Counsel (Dec. 2, 2004); Telephone Interview with OF (Oct. 20, 2004).

142. Prosecutor v. Babić, Case No. IT-03-72-A, Transcript of Appeals Proceedings, at 34 (Apr. $25,2005)$.

143. GÉrard Prunier, The RWANda Crisis: History of a Genocide 5 (1996); 1 Virginia Morris \& Michael P. Scharf, The International Criminal Tribunal For RWANDa 49-50 (1998). Rwanda's third group, the Twa, accounts for one percent or less of the population. PRUNIER, supra, at 5. 
centuries, ${ }^{144}$ but the Hutu gained control of the country at independence in $1962^{145}$ and thereafter perpetrated a series of massacres that drove nearly 100,000 Tutsi into exile in neighboring countries. ${ }^{146}$ The exiled Tutsi formed an army, the Rwandan Patriotic Front ("RPF"), and engaged in military clashes with the Rwandan government ${ }^{147}$ before the two sides entered into the Arusha Peace Accords in 1993. ${ }^{148}$ In April 1994, an airplane carrying the country's Hutu president was shot down and, immediately thereafter, extremist Hutu began killing large numbers of Tutsi and moderate Hutu, massacring between 500,000 and one million people in one hundred days. ${ }^{149}$ The violence came to an end in July 1994 when the RPF defeated the Rwandan army. ${ }^{150}$ Heeding calls for an international tribunal similar to the ICTY, ${ }^{151}$ the Security Council established the ICTR.

144. Paul J. Magnarella, Justice in Africa: RWANda's Genocide, Its Courts, and the UN CRIMINAL TRIBUNAL 3 (2000) (reporting that between the eleventh and fifteenth centuries, the Tutsi conquered central Rwanda and, in the mid-to-late nineteenth century, "the Tutsi conquered and firmly estahlished central control over much, hut not all, of Rwanda, despite the fact that they represented only about 10 per cent to 14 per cent of a population that was over 80 per cent Hutu").

145. PRUNIER, supra note 143, at 41-54; MAGNARELLA, supra note 144, at 12-13.

146. PRUNIER, supra note 143 , at 56, 61 (reporting that there existed 120,000 refugees by early 1962); see also MAGNARELLA, supra note 144, at 13 (noting that hy 1963 Hutu attacks had "resulted in thousands of Tutsi deaths and the flight of about 130,000 Tutsi to neighboring countries"); PHILIP GOUREVITCH, WE WISH TO INFORM YOU THAT TOMORROW WE WILL BE KILLED WITH OUR FAMILIES: STORIES FROM RWANDA 63-69 (1998) (reporting a Tutsi's experiences during periods of violence against the Tutsi); MORRIS \& SCHARF, supra note 143, at 47, 50 ("During the next few years [after 1959] over 100,000 Tutsis fled to neighhoring countries in the face of waves of mass killings."); Howard Ball, Prosecuting War CRIMES AND Genocide: The TwenTIETHCENTURY EXPERIENCE 150-60 (1999) (placing the 1962 Tutsi refugee total at 200,000); William A. Schahas, Justice, Democracy, and Impunity in Post Genocide Rwanda: Searching for Solutions to Impossible Problems, 1996 CRIM. L. F. 523, 523-24 (1996).

147. PRUNIER, supra note 143, at 93-120; MORRIS \& SCHARF, supra note 143, at 50; Christina M. Carroll, An Assessment of the Role and Effectiveness of the International Criminal Tribunal for Rwanda and the Rwandan National Justice System in Dealing with the Mass Atrocities of 1994, 18 B.U. INT'L L.J. 163, 168 (2000).

148. BALL, supra note 146, at 162; MAGNARELIA, supra note 144 , at $16-17$; MORRIS \& SCHARF, supra note 143, at 50-51; see also PRUNIER, supra note 143, at 159-91 (providing an indepth account of the process and outcome of forming the Arusha Peace Accords).

149. MORRIS \& SCHARF, supra note 143, at 53, 58; Madeline H. Morris, The Trials of Concurrent Jurisdiction: The Case of Rwanda, 7 DUKE J. COMP. \& INT'L L. 349, 351 (1997). For comprehensive descriptions of the massacres and the events leading up to the violence, see Human Rights Watch, Leave NONE to Tell the StoRy (1999) [hereinafter Leave None to TELL THE STORY]; PRUNIER, supra note 143.

150. LEAVE NONE TO TELL THE STORY, supra note 149 , at 301-02; see also MORRIS \& SCHARF, supra note 143 , at 58 (descrihing the final battles).

151. On June 28, 1994, the Commission on Human Rights of the United Nations reported on the gravity of the Rwandan situation. Report on the Situation of Human Rights in Rwanda, U.N. ESCOR, 51st Sess. II 18-28, U.N. Doc. E/CN.4/1995/7 (June 28, 1994). Three days later, the 
At the time of this writing, the ICTR has disposed of only nineteen cases involving twenty-five defendants, and, like the ICTY, it currently labors under Security Council pressure to close its doors within the next few years. However, despite its similar need to dispose of its cases expeditiously, the ICTR's experience with guilty pleas has been dramatically different from that of the ICTY. By December 2004, only three ICTR defendants had pled guilty during the nine years of the Tribunal's existence, and it had been four-andone-half years since the ICTR had received its last guilty plea. In December 2004, Vincent Rutaganira gave the Tribunal its fourth guilty plea, ${ }^{152}$ but the circumstances of that case provide little reason to believe that many future guilty pleas will be forthcoming. Section A will examine those four guilty pleas, and that examination will show that, although the ICTR blundered in the sentencing of its first guiltyplea case, the Trial Chambers and the prosecution learned from that mistake. Indeed, sentencing in the next two guilty-plea cases appeared to set the stage for a host of subsequent guilty pleas. Those pleas did not materialize, however, demonstrating that appropriate sentencing practices, while a necessary condition, are not a sufficient condition for the procurement of guilty pleas in the context of international crimes. Indeed, the ICTR prosecution's failure to induce defendants to plead guilty, despite considerable efforts, highlights the complex nature of international plea bargaining and the substantial influence of factors that would play little or no role in the context of domestic crimes. These factors will be examined in Section B, and they will place Section A's discussion of the ICTR's four guilty-plea cases in an entirely new light.

Security Council adopted Resolution 935 requesting the establishment of an impartial Commission of Experts to examine and analyze further evidence of grave violations of humanitarian law in Rwanda. S.C. Res. 935, U.N. SCOR, 49th Sess., 3400th mtg., U.N. Doc. S/RES/935 (July 1, 1994). Tbe Commission recommended either the creation of a new international criminal tribunal or the expansion of the ICTY's jurisdiction to cover crimes in Rwanda. Commission of Experts on Rwanda, Preliminary Report of the Independent Commission of Experts Established in Accordance with Security Council Resolution 935, 11 150-152, Annex to Letter from the Secretary-General to the President of the Security Council, U.N. Doc. S/1994/1125 (Oct. 1, 1994). 2004).

152. Prosecutor v. Rutaganira, Case No. ICTR-95-1C-I, Minutes of Proceedings (Dec. 8, 


\section{A. The ICTR's Guilty-Plea Cases}

\section{Kambanda}

Jean Kambanda was the Prime Minister of the interim government that presided over Rwanda during the 1994 genocide. Although apparently not one of the genocide's planners, ${ }^{153} \mathrm{Kambanda}$ admitted to actively implementing the genocide by, among other things, distributing arms and ammunition, setting up roadblocks to capture Tutsi, and using media broadcasts to incite and encourage the massacres. ${ }^{154}$ Kambanda was arrested in Kenya in July 1997.155 Before a lawyer had been appointed for him, Kambanda engaged in interviews with the prosecution, ${ }^{156}$ and he reportedly left these interviews with the belief that he would be sentenced to no more than three years' imprisonment if he pled guilty. ${ }^{157}$ In April 1998, then, Kambanda entered into a plea agreement with the prosecution and pled guilty to genocide and crimes against humanity. ${ }^{158}$ None of the sentencing promises that Kambanda believed he had received made their way into his plea agreement. Rather, the agreement expressly provided that the parties had made "no agreements, understandings or promises" with respect to Kambanda's sentence. ${ }^{159}$

Whether or not promises were made to Kambanda, it is customary for prosecutors to recommend a discounted sentence following a guilty plea. Kambanda's guilty plea might have been expected to carry particular mitigating weight in sentencing due to his high-level position. The ICTY in Plavšić, for instance, emphasized that Plavšić's former position as President of the Republika Srpska

153. Kambanda maintains that the role of Prime Minister was foisted on him. Prosecutor v. Kambanda, Case No. ICTR-97-23-I, Transcript at 20-21 (Sept. 3, 1998); LINDA MELVERN, CONSPIRACY TO MURDER: THE RWANDAN GENOCIDE 170-71 (2004)

154. Prosecutor v. Kambanda, Case No. ICTR-97-23-1, Plea Agreement Between Jean Kambanda and the Office of the Prosecutor, If 23-40 (Apr. 29, 1998) (on file with author) [hereinafter Kambanda Plea Agreement]; Prosecutor v. Kambanda, Case No. ICTR-97-23-S, Judgment and Sentence, I 39 (Sept. 4, 1998) [hereinafter Kambanda Judgment].

155. Kambanda Judgment, supra note 154, if 1.

156. Jean Kambanda v. The Prosecutor, Case No. ICTR 97-23-A, Provisional Appellant's Brief and Motions for Extension of the Time-Limits and for Admission of New Evidence on Appeal Pursuant to Rules 115 and 116 of the Rules of Procedure and Evidence, II 3-6 (Mar. 29, 2000) (on file with author) [hereinafter Kambanda's Appeals Briefl.

157. Telephone Interview with SK (Dec. 1, 2004); Telephone Interview with Howard Morrison, ICTR Defense Counsel for Justin Mugenzi (Dec. 2, 2004); Interview with BM in The Hague, Neth. (Nov. 8, 2004).

158. See generally Kambanda Plea Agreement, supra note 154.

159. Kambanda Judgment, supra note 154, I 48; Prosecutor v. Kambanda, Case No. ICTR97-23-I, Transcript at 6 (Sept. 3, 1998). 
enhanced the reconciliatory and truth-telling value of her guilty plea. ${ }^{160}$ Further, Kambanda had tendered his guilty plea before the completion of any ICTR trials; thus, his guilty plea, coming so early in the life of the ICTR, had the potential to set a powerful example for subsequent defendants to follow. Finally, Kambanda provided prosecutors with a wealth of information relevant to their investigations. Kambanda provided ninety hours of recorded testimony for use in subsequent trials of senior political and military leaders, ${ }^{161}$ information which the prosecution described as "invaluable," 162 and he promised to testify for the prosecution in those trials. ${ }^{163}$ Such cooperation is also ordinarily rewarded with a sentence reduction.

Despite these considerations, the prosecution recommended that Kambanda receive a life sentence ${ }^{164}$ - the harshest sentence the ICTR can impose ${ }^{165}$ - and one can surmise why it felt compelled to make such a recommendation. Indeed, the very same factors that might be thought to justify a significantly reduced sentence recommendation for Kambanda likely convinced prosecutors to recommend a term of life imprisonment. Kambanda was the second highest-ranking political authority in Rwanda during the genocide and was substantially involved in the implementation of the genocide. Thus, the prosecutors likely reasoned that if anyone deserved a life sentence, it was

160. Plavšić Sentencing Judgment, supra note 103, ๆ 80.

161. Prosecutor v. Kambanda, Case No. ICTR-97-23-1, Prosecutor's Pre-Sentencing Brief at 22-23 (Aug. 31, 1998) (on file with author) [hereinafter Kambanda Prosecutor's Pre-Sentencing Brief].

162. Id. at 22-23; Prosecutor v. Kambanda, Case No. 1CTR-97-23-I, Transcript at 12 (Sept. 3, 1998) (on file with author). The prosecution described Kambanda's cooperation as follows:

The accused has assisted the Prosecutor in interpreting the horrific events that occured [sic] in Rwanda between 7 April and 7 July 1994, as well as direct evidence involving other accused and suspects. Without disclosing the substance of his audio recorded statement, his testimony has enabled the Prosecutor to have first hand information, and evidence of such key facts as the meeting between the Council of Ministers and Prefets held on 11 April 1994, where the topic of massacres committed against the civilian population was raised; the contents of deliberations and decisions agreed upon by consensus in the numerous closed sessions of the Cabinet; the involvement of Ministers, senior Military officers and Prefets in the commission of offences within the jurisdiction of the Tribunal.

Kambanda Prosecutor's Pre-Sentencing Brief, supra note 161, at 23.

163. Kambanda Plea Agreement, supra note 154, If 42; see also Lawyer for the Former Rwandan Prime Minister Argues for Light Sentence, INTERNEWS (Sept. 4, 1998), available at http://www.internews.org/activities/ICTR_reports/ICTRNewsSep98.html (reporting prosecutor's comments that Kambanda would testify in the genocide trials of other government and military leaders).

164. Kambanda Judgment, supra note 154, I 60.

165. 1CTR Statute, supra note 8, art. 23(1). 
Kambanda. ${ }^{166}$ That perception carried all the more significance because Kambanda was convicted at the very outset of the ICTR, so the disposition of his case garnered particularly intense publicity. The prosecution did try to ameliorate the effect of its harsh sentencing recommendation on future plea negotiations by suggesting that any future application for pardon or commutation of sentence made by Kambanda "be considered favorably on the basis of past, current and future significant cooperation extended to the prosecution," 167 but beyond that it was not willing to go. The Trial Chamber apparently agreed with the prosecution's assessment of the case because it sentenced Kambanda to life imprisonment. ${ }^{168}$ Although the Trial Chamber recognized Kambanda's guilty plea as a mitigating factor, it held that the aggravating circumstances surrounding Kambanda's crimes "negate[d] the mitigating circumstances."169

The sentence infuriated Kambanda, and he immediately appealed, seeking to quash his guilty plea and proceed to trial. ${ }^{170} \mathrm{He}$ argued, among other things, that he had not been provided competent legal advice and that he had been inappropriately detained in isolation in a safe-house 500 kilometers from the detention facility where the other ICTR defendants are held. ${ }^{171}$ Kambanda also immediately ceased cooperating with the prosecution. ${ }^{172}$ After the Appeals Chamber rejected his appeal, ${ }^{173}$ the prospects for subsequent guilty pleas appeared dim: because Kambanda had received absolutely nothing for his guilty plea, it seemed unlikely that future defendants would choose to waive their right to trial.

\section{Serushago}

Omar Serushago did waive his right to trial, pleading guilty to genocide and crimes against humanity in December 1998-three months after Kambanda received his life sentence-but Serushago's

166. The prosecution had previously recommended a life sentence for Jean Paul Akayesu, a sentence which the Trial Chamber imposed, and Akayesu was only a mayor of the Taba commune. Prosecutor v. Akayesu, Case No. ICTR-96-4-T, Judgment, I 54 (Sept. 2, 1998) [hereinafter Akayesu Judgment]; Prosecutor v. Akayesu, Case No. ICTR-96-4-T, Transcript of Sentencing Hearing (Oct. 2, 1998).

167. Kambanda Prosecutor's Pre-Sentencing Brief, supra note 161, at 2.

168. Kambanda Judgment, supra note 154, at Verdict.

169. Id. थ| 62 .

170. Kambanda v. Prosecutor, Case No. ICTR-97-23-A, Judgment, of 3 (Oct. 19, 2000) [hereinafter Kambanda Appeals Judgment].

171. Kambanda's Appeals Brief, supra note 156, ๆๆ 2-10.

172. Letter from Carla Del Ponte to Agwu Okali, ICTR Registrar (Apr. 25, 2000) (on file with author).

173. Kambanda Appeals Judgment, supra note 170, ๆ 126. 
decision to plead guilty was made long before the decision in Kambanda was handed down. Serushago was a low-level leader of a small group of militiamen. He supervised a roadblock at which Tutsi were detained and killed, and he admitted to killing four people himself. ${ }^{174}$ Residing in Nairobi following the Rwandan massacres, Serushago approached ICTR prosecutors in April 1997 and provided them information ${ }^{175}$ that led, among other things, to the arrest of several high-ranking ICTR defendants including Kambanda and Georges Ruggiu, ${ }^{176}$ whose case will be discussed next. In July 1998, Serushago voluntarily surrendered to the ICTR even though he had not been indicted by the Tribunal, ${ }^{177}$ and, soon after the indictment was prepared, he pled guilty to it.178 Serushago's motives for bringing himself before the ICTR may never be known. Some believe that he underwent a religious conversion that made clear to him his wrongful conduct while others note that he received approximately $\$ 5,000$ from the ICTR prosecution. Serushago maintained that the money was used "to pay for taxis and assist the Prosecution in arrests," 179 but not all are convinced that the money was intended only for those purposes. Whatever his motivation, Serushago may have experienced some misgivings when he learned of Kambanda's life sentence, but his substantial cooperation and voluntary surrender likely gave him little choice at that point but to adhere to his plan to plead guilty.

As in Kambanda, the prosecution made Serushago no written promises regarding its sentence recommendation; indeed, Serushago's plea agreement provides that sentencing "is at the entire discretion of the Trial Chamber." 180 When the time came to recommend a sentence, however, the prosecution did provide Serushago some consideration for his plea. Because Serushago was a low-level defendant whose case had not generated significant publicity, prosecutors - as well as the

174. Prosecutor v. Serushago, Case No. ICTR-98-39-S, Sentence, If 25 (Feb. 5, 1999) [hereinafter Serushago Sentence].

175. Prosecutor v. Serusbago, Case No. ICTR-98-39, Transcript at 15-16 (Jan. 19, 1999) [hereinafter Serusbago Transcript] (on file with author).

176. Serushago Sentence, supra note 174, I 32; Serushago Transcript, supra note 175, at 11; see also Press Release, ICTR, Rwanda: First Non-Rwandese Suspect Arrested, ICTR/INFO-9-2062 (July 23, 1997) (reporting the arrest of Georges Ruggiu); Press Release, IC'TR, Rwanda: Top Figures of Former Regime Arrested, ICTR/INFO-9-2-61 (JuIy 18, 1997) (reporting Kambanda's arrest).

177. Serushago Sentence, supra note 174, ๆ $1,34$.

178. Id. II 2, 4; Prosecutor v. Serushago, Case No. ICTR-98-37, Plea Agreement Between Omar Serushago and the Office of the Prosecutor (Dec. 4, 1998) [hereinafter Serushago Plea Agreement] (on file with author).

179. Prosecutor v. Nahimana et al., Case No. ICTR-99-52-T, Judgment and Sentence, If 824 (Dec. 3, 2003) [hereinafter Nahimana Judgment].

180. Serushago Plea Agreement, supra note 178, ๆ 40. 
Trial Chamber for that matter-likely felt more able than in Kambanda to discount Serushago's sentence without giving rise to ruinous publicity. The prosecution accordingly lauded Serushago's substantial cooperation ${ }^{181}$ and put forth a sentence recommendation of not less than twenty-five years' imprisonment. ${ }^{182}$ At the time the prosecution made that recommendation, it had recommended sentences of life imprisonment in every previous case in which it made a recommendation. ${ }^{183}$ And the Trial Chambers had imposed life sentences in each of those cases. ${ }^{184}$ In every subsequent case that has gone to trial, the prosecution has likewise recommended a life sentence. ${ }^{185}$ Thus, the twenty-five-year sentence that the prosecution recommended for Serushago can be understood to reflect a discount for his guilty plea and cooperation, as does the fifteen year sentence that the Trial Chamber in fact imposed. ${ }^{186}$ Indeed, only three other ICTR defendants have received more lenient sentences than Serushago, and two of them were the remaining two defendants who pled guilty. ${ }^{187}$

181. The prosecution maintained that Serushago had cooperated in four distinct ways: by assisting in the arrest of other defendants; by providing information in other cases and agreeing to testify in those cases; by providing a detailed account of his own criminal conduct; and by voluntarily surrendering. Serushago Transcript, supra note 175 , at 10-12.

182. Id. at 15 .

183. Kambanda Judgment, supra note 154, If 60; Prosecutor v. Akayesu, Case No. ICTR-96. 4-T, Sentence (Oct. 2, 1998) [hereinafter Akayesu Sentence]; Prosecutor v. Kayishema \& Ruzindana, Case No. ICTR 95-1-T, Judgment, Sentence If 25 (May 21, 1999) (hereinafter Kayishema \& Ruzindana Judgment].

184. Kambanda Judgment, supra note 154, at Verdict; Akayesu Sentence, supra note 183; Kayishema \& Ruzindana Judgment, supra note 183, ๆๆ 27-28.

185. Prosecutor v. Ndindabahizi, Case No. ICTR-2001-71-I, Judgment and Sentence, ๆ 503 (July 15, 2004); Prosecutor v. Gacumbitsi, Case No. ICTR-2001-64-T, Judgment, ף 338 (June 17, 2004); Prosecutor v. Ntagerura et al., Case No. ICTR-99-46-T, Judgment and Sentence, If 815 (Feb. 25, 2004); Prosecutor v. Nahimana et al., Case No. ICTR-99-52-T, Judgment and Sentence, I 1097 (Dec. 3, 2003) [hereinafter Nahimana Judgment]; Prosecutor v. Kajelijeli, Case No. ICTR98-44A-T, Judgment and Sentence, If 956 (Dec. 1, 2003); Prosecutor v. Niyitegeka, Case No. ICTR-96-14-T, Judgment and Sentence, If 489 (May 16, 2003); Prosecutor v. Semanza, Case No. ICTR-97-20-T, Judgment, If 558 (May 15, 2003); Prosecutor v. Elizaphan and Gérard Ntakirutimana, Case Nos. ICTR-96-10 \& ICTR-96-17-T, Judgment and Sentence, ๆ 890 (Feb. 21, 2003) [hereinafter Ntakirutimana Judgment]; Prosecutor v. Musema, Case No. ICTR-96-13-A, Judgment and Sentence, ๆ 994 (Jan. 27, 2000); Prosecutor v. Rutaganda, Case No. ICTR-96-3, Judgment and Sentence, ๆ 464 (Dec. 6, 1999). The Trial Chamber did not report the prosecution's sentence recommendation in the Kamuhanda case. Prosecutor v. Kamuhanda, Case No. ICTR95-54A-T, Judgment, If 753-760 (Jan. 22, 2004). However, the fact that the Trial Chamber sentenced Kamuhanda to life imprisonment strongly indicates that the prosecution recommended a life sentence in that case as well. $I d$. If 770 .

186. Prosecutor v. Serushago, Case No. ICTR-98-39-S, Sentence, Verdict (Feb. 5, 1999).

187. The only defendant to receive a more lenient sentence after trial was Elizaphan Ntakirutimana, who was sentenced to ten years' imprisonment. Ntakirutimana Judgment, supra note 185, ๆ 921. Ntakirutimana's advanced age and poor health contributed to the leniency of his sentence. See id. ๆ 989. 


\section{Ruggiu}

Georges Ruggiu, a Belgian, became interested in Rwandan politics in the early 1990s after befriending some Rwandan students who were his neighbors in Belgium. ${ }^{188}$ Ruggiu met with Rwandan President Habyarimana on a number of occasions, and he participated in political debates in Belgium regarding Rwanda. ${ }^{189}$ Ruggiu, believed by some to be a passionate idealist ${ }^{190}$ and by others to be mentally unbalanced, ${ }^{191}$ became radically opposed to the $R P F$, which had been engaged in an armed conflict with the Hutu-led Rwandan government. ln late 1993, Ruggiu moved to Rwanda apparently to marry ${ }^{192}$ and to work as a journalist and broadcaster for the Radio Television Libre des Mille Collines ("RTLM"). During the spring of 1994, RTLM broadcasts, including those by Ruggiu, incited the population to kill Tutsi. ${ }^{193}$

A year after the atrocities, Ruggiu authored a book proclaiming his innocence and maintaining that the RTLM broadcasts were intended to inobilize Rwandans against the RPF, not against Tutsi

188. Prosecutor v. Ruggiu, Case No. ICTR-97-32-I, Judgment and Sentence, I 38 (June 1, 2000) [hereinafter Ruggiu Judgment]. At Ruggiu's pre-sentencing hearing, his lawyer maintained that Ruggiu "had come to know Rwanda through highly partisan friends who gave him a biased idea of the political situation in the country." How Belgian Journalist Became Involved in Hate Media, INTERNEws, May 15, 2000, available at http://www.internews.org/ activities/ICTR_Reports/ICTRNewsMay00.html\#may15c; see also Prosecution v. Ruggiu, Case No. ICTR-97-32-I, Transcript at 109-12 (May 15, 2000) [hereinafter Ruggiu Transcript] (on file with author).

189. Ruggiu Judgment, supra note 188 , I 41.

190. Ruggiu Transcript, supra note 188, at 115, 146, 149.

191. See Convicted Ex-Radio Presenter has Mental Problems, Defence Suggests, HIRONDELLE NEwS AGENCY, Mar. 2, 2002, available at http://www.hirondelle.org/hirondelle.nsf/0 /c319ac23033fcelac1256721007ae237 (reporting Ruggiu's counsel's claims that the defendant suffered from "emotional problems") [hereinafter Convicted Ex-Radio Presenter]; Telephone Interview with MI (Dec. 2, 2004); Telephone Interview with PK (Nov. 23, 2004).

192. Ruggiu Transcript, supra note 188, at 113. At his sentencing hearing, one of Ruggiu's former colleagues testified that Ruggiu found in his Rwandan friends a warm and accepting adopted family. Id. at 149-50.

193. Ruggiu Judgment, supra note 188 , IT 42, 44(iv)-(v), 50; see also PRUNIER, supra note 143 , at 200 (reporting that the radio station RTLM "poured out a torrent of propaganda, mixing constant harping on the old themes of 'majority democracy,' fears of 'Tutsi feudalist enslavement' and ambiguous 'calls to action."); Schabas, supra note 146, at 524 ("They set up a private radio station, Radio-Television Libre Mille-Collines, which battered Rwanda with hate propaganda over the following months."). See generally Nahimana Judgment, supra note 185 (convicting radio and newspaper officials of genocide and direct and public incitement to commit genocide); Mark A. Drumbl, Rule of Law Amid Lawlessness: Counseling the Accused in Rwanda's Domestic Genocide Trials, 29 COLUM. HUM. RTS. L. REV. 545, 559 (1998) ("During this time period, the Hutu government began to develop a propaganda machine calculated to instill in the Hutu citizenry a fear of the Tutsi."). For a comprehensive treatment of Hutu hate propaganda, see LEAVE NONE TO TELL THE STORY, supra note 149, at 65-95. 
civilians. ${ }^{194}$ Not surprisingly, then, after he was arrested, Ruggiu pled not guilty. He later contended that he remained convinced of his innocence until one of his co-defendants made a speech to the other ICTR detainees, informing them that the Rwandan violence had in fact been a planned genocide. ${ }^{195}$ Ruggiu reported that this news caused him great distress and led him to engage in interviews with the prosecution. ${ }^{196}$ He reported that after serious reflection, he recognized his moral responsibility to tell the truth and to plead guilty to direct and public incitement to commit genocide. ${ }^{197}$

During this time, Ruggiu's lawyers made efforts to obtain firmer sentencing guarantees than prosecutors had provided Kambanda. ${ }^{198}$ On the surface, these efforts failed: Ruggiu's plea agreement, like Kambanda's and Serushago's, contains no promises regarding the prosecution's sentencing recommendation. ${ }^{199}$ But at the same time, the prosecution clearly recommended a reduced sentence for Ruggiu as a result of the guilty plea. The Prosecutor recommended a twenty year prison sentence for Ruggiu, ${ }^{200}$ the shortest sentence ICTR prosecutors had theretofore ever recommended. In addition, and presumably to encourage future guilty pleas, the Prosecutor expressly stated that she would have recommended a life sentence had Ruggiu proceeded to trial. ${ }^{201}$

The Trial Chamber likewise seemed intent on encouraging future guilty pleas. As noted above, the Kambanda Trial Chamber, by

194. I Lied in My Book to Protect RTLM, Says Convicted Radio Presenter, HIRondELLE NEwS AGENCY, Feb. 28, 2002, available at http://www.hirondelle.org/hirondelle.nsf/caefd9edd 48f5826c12564cf004f793d/c319ac23033fcelac1256721007ae237.

195. Ruggiu Transcript, supra note 188 , at 47.

196. Id. at 47-56. It was later revealed that Ruggiu lied to prosecutors in some of these early interviews. Convicted Ex-Radio Presenter has Mental Problems, Defense Suggests, supra note 191.

197. Ruggiu Transcript, supra note 188, at 56-59; Plea Agreement Between Georges Ruggiu and the Office of the Prosecutor, II 2, 4, Prosecutor v. Ruggiu, Case No. ICTR-97-32-DP (May 12, 2000) [hereinafter Ruggiu Plea Agreement].

198. Hate Radio Presenter Set to Plead Guilty to Genocide Charges, Hirondelle News AGENCY, May 9, 2000, http://www.hirondelle.org/hirondelle.nsf/caefd9edd48f5826c12564cf004f 793d/c319ac23033fce1ac1256721007ae237.

199. Ruggiu Plea Agreement, supra note 197, I 220. Prosecutors emphasized this point, both in the press, see, e.g., Portrait of Georges Ruggiu, Journalist who Incited Genocide, HIRONDELLE NEwS AGENCY, May 14, 2000, http://www.hirondelle.org/hirondelle.nsf/caefd9edd48f5826c12564 cf004f793d/c319ac23033fcelac1256721007ae237 ("Since Ruggiu started confessing, his lawyers say they have reached an agreement with prosecutors that will govern the legal and factual framework of the case. They stress, however, that this accord contains no 'parallel promises[.]"), and to the Trial Chamber, see, e.g., Ruggiu Transcript, supra note 188, at 66 (detailing Prosecutor Carla Del Ponte's vehement assertion that no promises had been made to Ruggiu).

200. Ruggiu Transcript, supra note 188, at 190.

201. Id. at 188. 
sentencing Kambanda to the harshest sentence available to it, did nothing to motivate subsequent ICTR defendants to plead guilty. The Serushago Trial Chamber did appear to treat Serushago more leniently as a result of his guilty plea, but the Trial Chamber did not discuss in any detail the mitigating role that Serushago's guilty plea played in his sentence. The Ruggiu Trial Chamber, by contrast, explicitly praised guilty pleas. ${ }^{202}$ It lauded Ruggiu's guilty plea for "sparing the Tribunal a lengthy investigation and trial" 203 and for reflecting Ruggiu's "acknowledgement of his mistakes" which, according to the Trial Chamber, constituted "a healthy application of reason and sentiment." 204 Most importantly, the Trial Chamber announced to other defendants that "some form of consideration" would be shown to defendants who plead guilty "in order to encourage other suspects and perpetrators of crimes to come forward." 205 The Trial Chamber then sentenced Ruggiu to twelve years' imprisonment, a sentence that was subsequently blessed by the prosecution. Although the government of Rwanda sharply criticized Ruggiu's sentence, the ICTR's Chief of Prosecutions described it as "a good gesture for other accused who would wish to plead guilty and accept responsibility for their crimes."206

If ICTR defendants considered sentencing discounts to be an influential incentive to plead guilty, then by June 2000 the ICTR should have been poised to receive a substantial number of guilty pleas. Although, until Ruggiu, the prosecution had made no express promises regarding its sentencing recommendations, a comparison of its recommendations following trials-all of which stood at life imprisonment-and its recommendations in Serushago and Ruggiu showed a prosecutorial practice of recommending discounted sentences for defendants who pled guilty. And even if defendants

202. Some believe that the differing treatment given to guilty pleas in ICTR cases relates less to an overall evolution in the Tribunal's assessment of guilty pleas and more to the backgrounds of the particular judges involved in the cases. Telephone Interview with WM (Oct. 19, 2005). Judge Kama, for instance, who presided over the Kambanda and Serushago cases, hailed from Senegal, a civil-law country, while Judge Pillay hailed from South Africa, a commonlaw country. As a general matter, ICTY and ICTR judges originating in civil-law countries appear less comfortable with plea bargaining than judges from common-law countries, presumably because bargaining is not so prevalent in civil-law countries. For a description of bargaining and bargaining analogues in Continental civil-law countries, see Combs, supra note 56 , at $37-46$.

203. Ruggiu Judgment, supra note 188, ๆ 53.

204. Id. ๆ 55.

205. Id.

206. Rwanda Unhappy with Ruggiu Sentence, Hirondelle News AGENCY, June 1, 2000, available at http://www.hirondelle.org/hirondelle.nsf/caefd9edd48f5826c12564cf004f793d/c319ac2 3033fce1ac1256721007ae237. 
remained uneasy about the prosecution's sentencing recommendations, the Ruggiu Trial Chamber's clear announcement that Trial Chambers would compensate guilty pleas with sentencing concessions might have been expected to reassure them. No ICTR defendant tendered a guilty plea for four-and-one-half years, however, until Vincent Rutaganira pled guilty in December 2004.

\section{Rutaganira}

Vincent Rutaganira served as conseiller of the Mubuga sector, Gishyita Commune, Kibuye Prefecture ${ }^{207}$ from 1980 to $1994 .^{208}$ The Prosecutor's charges against Rutaganira centered on a massacre of Tutsi that took place at the church in Mubuga. Between 4,000 and 5,000 Tutsi had sought refuge in the church, and all but a few were killed during a three-day massacre in April 1994. ${ }^{209}$ The indictment charged that Rutaganira and two others had ordered the attack on the church and had personally participated in the killings. ${ }^{210}$ On the basis of these allegations, the indictment charged Rutaganira with six counts: genocide, extermination as a crime against humanity, murder as a crime against humanity, inhumane acts as a crime against humanity, a violation of Article Three common to the Geneva Conventions, and a violation of Additional Protocol II to the 1949 Geneva Conventions. ${ }^{211}$

Rutaganira had fled Rwanda after the massacres and was still at large at the time the Prosecutor issued the indictment against him in 1996. In February 2002, Rutaganira voluntarily surrendered to the Tribunal, ${ }^{212}$ and by the time he pled guilty, eight-and-one-half years after his indictment, the prosecution was prepared to take a very different view of the crimes he had committed. In particular, in his plea agreement, Rutaganira admitted only to omissions; that is, he denied both ordering the attack on the church and participating in the attack, the charges that had formed the basis for his original indictment. Rather, he admitted only that he was aware that Tutsi civilians had gathered in the church, that he was aware that assailants were gathering near the church before the attack took place, and that

207. Rwanda is divided into eleven prefectures, and each of these prefectures is further divided into communes, which are themselves divided into sectors.

208. Prosecutor v. Kayishema et al., Case No. ICTR-95-1-I, First Amended Indictment II 28 (Apr. 29, 1996) [hereinafter Rutaganira Indictment].

209. Prosecutor v. Kayishema \& Ruzindana, Case No. ICTR 95-1-T, Judgment, 19392,404 (May 21, 1999).

210. Rutaganira Indictment, supra note 208 , ๆ 51.

211. Id. I 60.

212. Prosecutor v. Rutaganira, Case No. ICTR-95-1C-T, Transcript at 7 (Jan. 17, 2005) (on file with author) [hereinafter Rutaganira Transcript]. 
"despite the fact that he was conseiller of Mubuga secteur he failed to protect the Tutsi who had sought refuge" in the church..$^{213}$

As part of the plea agreement, Rutaganira pled guilty to only one count: aiding and abetting extermination as a crime against humanity on the basis of his omissions: Pursuant to the plea agreement, the prosecution did not seek merely to withdraw the remaining counts of genocide, crimes against humanity, and war crimes, but rather asked the Court to acquit Rutaganira of those counts because, the prosecution maintained, there did not exist sufficient evidence to convict him. ${ }^{214}$ As for the sentence to impose on Rutaganira, the prosecution agreed to recommend a sentence of between six and eight years' imprisonment, and it further agreed to recommend that Rutaganira serve his sentence either in a European country or in the Kingdom of Swaziland. ${ }^{215}$ Finally, the plea agreement makes clear that Rutaganira would not cooperate with the prosecution. ${ }^{216}$ The Trial Chamber acceded to the prosecution's request and acquitted Rutaganira of the charges to which he did not plead guilty. The Trial Chamber sentenced Rutaganira to six years' imprisonment, ${ }^{217}$ the shortest sentence ever imposed by the ICTR.

Rutaganira represents the first case of overt sentence bargaining at the ICTR as it is the first case in which the prosecution was willing to commit to recommending a specific range of sentences in exchange for the defendant's guilty plea. Rutaganira also represents the first ICTR charge bargain, ${ }^{218}$ but it is not the typical sort of charge bargain prevalent in national criminal justice systems. In the typical charge bargain, prosecutors agree to withdraw provable counts in exchange for the defendant's guilty plea. Rutaganira's plea agreement appears to reflect a typical charge bargain because Rutaganira admitted to facts substantially less serious than the facts that formed the basis of his indictment, but it differs in that the prosecution apparently was willing to accept Rutaganira's meager admissions

213. Id. at 10-11.

214. Id. at 2-3.

215. Id. at 8 . As noted infra, most ICTR convicts have been sent to serve their sentences in Mali.

216. Id. at 29.

217. Prosecutor v. Rutaganira, Case No. ICTR-95-1C-T, Judgment and Sentence (Mar. 14, 2005).

218. A charge bargain appeared to take place in Serushago but likely did not. Serushago's initial indictment charged him with five counts: genocide, and murder, extermination, torture, and rape as crimes against humanity. Prosecutor v. Serushago, Case No. ICTR-98-39-I, Modified Indictment at 20-24 (Oct. 14, 1998). Serushago pled guilty to four of the counts, and the prosecution dropped the count of rape as a crime against humanity. Prosecutor v. Serushago, Case No. ICTR 98-39-S, Sentence, II 2-4. According to prosecutors, the rape charge was withdrawn for Iack of evidence to prove the charge. 
because it truly did not have the evidence to prove the original charges at trial. The prosecution said as much during Rutaganira's sentencing hearing, admitting that its "chances of success in proving all the charges against him was ... extremely low"219 because the Prosecutor was "not in possession of any evidence... which indicates that $\mathrm{Mr}$. Rutaganira himself was implicated in the planning of the said attack, ... nor does [the Prosecutor] possess any evidence ... indicating that Mr. Rutaganira's role in the said attack at Mubuga church was premeditated."220

The evidence and testimony at Rutaganira's sentencing hearing supported the prosecution's representations. Witnesses testified, for instance, that Rutaganira and his wife had hidden two Tutsi girls and a Tutsi woman in their home during the massacres, despite the fact that the Rutaganiras themselves would have been killed had their assistance to the three Tutsi been revealed. ${ }^{221}$ Another Tutsi witness testified that Rutaganira had saved her life by telling assailants that she was a Hutu, ${ }^{222}$ while others testified that Rutaganira had been on very good terms with Tutsi before the killings, acting as a godfather to a number of Tutsi children and asking Tutsi to be godparents to some of his children. ${ }^{223}$ Finally, after the 1994 violence, Mrs. Rutaganira returned to the same town in Rwanda in which the Mubuga church massacres took place, and she was appointed Deputy Mayor for Women's Development. That she holds a political position in Rwanda's current Tutsi-led government reinforces the prosecution's assertions that no compelling evidence exists to link Rutaganira with the planning or implementation of the killings at Mubuga church.

Thus, the dramatic difference between the factual basis of Rutaganira's indictment and the factual basis of his guilty plea appear to have resulted from evidentiary insufficiencies rather than from charge bargaining. Rutaganira's plea deal should nonetheless be considered a charge bargain because the prosecution asked the Trial Chamber to acquit Rutaganira of the remaining charges of crimes against humanity and war crimes for lack of evidence. ${ }^{224}$

219. Rutaganira Transcript, supra note 212 , at 8 .

220. Id.

221. Id. at 20, 24-25, 31 .

222. Id. at 15-16.

223. Id. at 20, 24

224. The prosecution also asked the Trial Chamber to acquit Rutaganira of genocide, but that request is in keeping with the factual basis of Rutaganira's guilty plea. One cannot commit genocide without having the specific intent to commit genocide. See Prosecutor v. Kayishema \& Ruzindana, Case No. ICTR 95-1-T, Judgment, I 91 (May 21, 1999) ("A distinguishing aspect of the crime of genocide is the specific intent (dolus specialis) to destroy a group in whole or in part. . . It is this specific intent that distinguishes the crime of genocide from the ordinary crime 
Extermination as a crime against humanity-the crime to which Rutaganira pled guilty-is a more serious crime than murder as a crime against humanity because extermination requires proof of "an element of mass destruction which is not required for murder."225 Therefore, if the prosecution possessed sufficient evidence to convict Rutaganira of aiding and abetting extermination as a crime against humanity, that evidence must have been sufficient to convict him of aiding and abetting in murder and inhumane acts as crimes against humanity. It is not surprising that the prosecution would desire to eliminate those charges once Rutaganira pled guilty to extermination: all of the counts related to the same conduct that formed the basis for the extermination charge. In such cases, prosecutors commonly withdraw counts that are less serious than the counts to which the defendant pleads guilty. The distinctive feature of Rutaganira, however, is that the prosecution did not seek merely to withdraw the less serious counts but rather to have the Trial Chamber acquit Rutaganira of those counts on the basis of insufficient evidence. That request is implausible on its face, given Rutaganira's guilty plea to the more serious crime of extermination, and one can only assume that prosecutors agreed to advance this improbable position on the insistence of Rutaganira himself. As the following discussion will reveal, that insistence indeed reflects the mind-set of most ICTR defendants and sheds light on the difficulties facing ICTR prosecutors who seek to procure guilty pleas.

\section{B. The Dearth of ICTR Guilty Pleas: The Insignificant Influence of Sentence Discounts}

Although ICTR prosecutors failed to obtain any guilty pleas during the four-and-one-half years between the guilty pleas in Ruggiu and Rutaganira, it was not for their lack of effort. Prosecutors initiated plea discussions in a number of cases and not only offered generous sentencing concessions, ${ }^{226}$ but also indicated a willingness to negotiate over other issues of potential interest to defendants. Both the Rutaganira plea agreement and my interviews suggest that ICTR prosecutors are now routinely willing to commit to recommending a

of murder."). Thus, because Rutaganira admitted only to failing to protect the Tutsi, the prosecution did in fact lack sufficient evidence to convict him of genocide.

225. Prosecutor v. Akayesu, Case No. ICTR-96-4-T, Judgment, If 591 (Sept. 2, 1998) [hereinafter Akayesu Judgment].

226. Telephone Interview with TH (Nov. 24, 2004); Telephone Interview with MI (Dec. 2, 2004); Telephone Interview with MK (Dec. 1, 2004); Telephone Interview with RQ (Dec. 1, 2004). 
sentence within a narrow range of sentences. ${ }^{227}$ Although defendants still have no guarantee that a Trial Chamber will sentence within the prosecution's recommended range, the fact that ICTR Trial Chambers most commonly sentence defendants to life imprisonment after trials ${ }^{228}$ means that even defendants who do not obtain the precise sentence that they bargained for are likely to garner some benefit from a guilty plea. Further, unlike prosecutors in national criminal justice systems who have the ability to bargain only over the duration of the sentence, ICTR prosecutors can offer defendants additional benefits in exchange for their guilty pleas. As the following discussion will show, the location at which the defendant will serve his sentence had for years been a potentially fertile field for negotiation before it became an express term in the Rutaganira plea agreement. And in more recent times, the prosecution has made plans to transfer some cases to Rwanda for trial; that threat of transfer could likewise constitute a compelling bargaining chip.

Turning first to the location of a defendant's detention, the ICTR Statute provides that convicted persons must serve their sentences in Rwanda or in any State that has indicated its willingness to accept convicted defendants. ${ }^{229}$ Until lately, the only countries that had agreed to accept ICTR convicts were Mali, the Republic of Benin, and the Kingdom of Swaziland, ${ }^{230}$ and virtually all ICTR defendants convicted thus far have been sent to serve their sentences in a prison in Bamako, Mali. ${ }^{231}$ Recently, however, three European countries-

227. Telephone Interview with MI (Dec. 2, 2004); Telephone Interview with MK (Dec. 1, 2004); Telephone Interview with PK (Nov. 23, 2004); Telephone Interview with RQ (Dec. 1, 2004).

228. Ten of the seventeen ICTR defendants who proceeded to trial received life sentences. Akayesu Judgment, supra note 225, at Sentence; Prosecutor v. Kayishema \& Ruzindana, Case No. ICTR-95-1-T, Judgment, Sentence If 32 (May 21, 1999); Prosecutor v. Musema, Case No. ICTR-96-13-A, Judgment and Sentence, I 1008 (Jan. 27, 2000); Prosecutor v. Niyitegeka, Case No. ICTR-96-14-T, Judgment and Sentence, I 502 (May 16, 2003); Prosecutor v. Rutaganda, Case No. ICTR-96-3, Judgment and Sentence, If 473 (Dec. 6, 1999); Nahimana Judgment, supra note 185, at ๆी 1105, 1108 (Dec. 3, 2003) (sentencing Nahimana and Ngeze to life sentences); Prosecutor v. Kajelijeli, Case No. ICTR-98-44A-T, Judgment and Sentence, 968 (Dec. 1, 2003); Prosecutor v. Ndindabahizi, Case No. ICTR.2001-71-I, Judgment and Sentence, If 511 (July 15, 2004); Prosecutor v. Kamuhanda, Case No. ICTR.95-54A-T, Judgment, ๆ 770 (Jan. 22, 2004). An eleventh defendant, Jean-Bosco Barayagwiza, would have received a life sentence, but the Trial Chamber reduced his sentence to thirty-five years' imprisonment to remedy the prosecution's violation of his procedural rights. Nahimana Judgment, supra note 185, भा 1106-07.

229. ICTR Statute, supra note 8, art. 26.

230. International Criminal Tribunal for Rwanda [CTR], Fact Sheet No. 6: International Cooperation with the Tribunal, http://65.18.216.88/ENGLISH/factsheets/6.htm (last visited Jan. 31, 2006).

231. See Rwandan War Crimes Court Postpones Ministers' Trial Until February, AGENCE FrANCE-PRESS, Oct. 30, 2004 ("Kambanda and five other convicts are currently jailed in Mali. 
France, Italy, and Sweden-signed accords in which they agreed to imprison ICTR convicts, and France ratified its accord in May 2004. ${ }^{232}$ Just how much influence ICTR prosecutors can have over the locationof-detention decision is unclear, since it is a determination typically made by the President of the Tribunal; for a few years now, however, prosecutors have at least been willing to pursue discussions on the issue. ${ }^{233}$ Ruggiu's plea bargain, in fact, was said to have included an unofficial prosecutorial promise to transfer Ruggiu to Italy, where some of his family resides. ${ }^{234}$

The most obvious benefit to an ICTR defendant of detention in a European prison relates to the more comfortable conditions in which the defendant will be held. ${ }^{235}$ That the families of many high-level ICTR defendants have relocated to European countries makes a European imprisonment all the more attractive. Perhaps most importantly, defendants imprisoned in Europe are typically eligible for release after they have served one-half to two-thirds of their sentences, ${ }^{236}$ a benefit not guaranteed to those imprisoned in Mali. Thus, ICTR defendants sent to European prisons may not only serve their sentences in greater comfort, but may serve significantly shorter sentences than defendants who are sentenced to the same term of imprisonment but who serve their terms in Mali.

As important as the location-of-detention question may be to an ICTR defendant, the location-of-trial question is even more important. To comply with the Security Council's instruction that the ICTR complete its work by 2010 , the Tribunal has committed to transferring some of its cases to national courts in Rwanda. ${ }^{237}$ Prosecutors compiled

Three other people who have been given sentences without further appeal are still being held in ICTR cells, waiting for a country to take them in.").

232. France Ratifies Rwanda Accord, AGENCE FRANCE-PRESSE, June 11, 2004.

233. Telephone Interview with TH (Nov. 24, 2004); Telephone Interview with MK (Dec. 1, 2004); Interview with BM, in The Hague, Neth. (Nov. 8, 2004).

234. Telephone Interview with TH (Nov. 24, 2004); Telephone Interview with PK (Nov. 29, 2004); Interview with BM, in The Hague, Neth. (Nov. 8, 2004).

235. Although ICTR convicts detained in Mali are housed in special facilities prepared with UN financial aid, these facilities cannot compare with the roomier, better-equipped prisons of Europe.

236. See, e.g., Richard S. Frase, Comparative Criminal Justice as a Guide to American Law Reform: How Do the French Do It, How Can We Find Out, and Why Should We Care?, 78 CAL. L. REV. 539, 649 n.569 (1990) (reporting that French sentences are reduced by one-half for good behavior); Mary Margaret Penrose, Lest We Fail: The Importance of Enforcement in International Criminal Law, 15 AM. U. INT'L L. REV. 321, $382 \mathrm{n} .225$ (reporting that an ICTY defendant imprisoned in Norway is eligible for parole after serving half of his sentence if he is a first time offender); see also Ivana Nizich, International Tribunals and their Ability to Provide Adequate Justice: Lessons from the Yugoslav Tribunal, 7 ILSA J. INT'L \& COMP. L. 353, 367-68 (2001) (describing Western European parole laws as "infinitely more lenient" than those in other parts of the world).

237. See supra text accompanying note 72 . 
a tentative list of cases for transfer, but they did not make this list public $^{238}$ for fear of the defendants' reaction. ${ }^{239}$ The prospect of a Rwandan prosecution terrifies some defendants, who believe that they will suffer physical abuse or even death if they return to Rwanda. That fear motivated ICTR defendants to conduct a high-profile protest in September 2004, when forty-four of the ICTR's fifty-six detainees boycotted their trials and threatened to launch hunger strikes. ${ }^{240}$ Given the depth of the defendants' disquiet, the ability to transfer a case to Rwanda provides prosecutors with a potent bargaining chip. Indeed, although the prosecution had expected Rutaganira to plead guilty soon after his voluntary surrender in 2002 , it was not until the prosecution made clear that it intended to transfer his case to Rwanda that Rutaganira decided to enter his guilty plea. ${ }^{241}$

The above discussion indicates that ICTR prosecutors should be in a strong position to procure guilty pleas. Prosecutors are willing and able to offer substantial sentencing concessions to defendants who plead guilty, and these concessions should be all the more valuable since the sentences imposed after trials have been so severe. Prosecutors additionally have the ability to bargain with defendants over the location of their detention and even over the criminal justice system in which their case will be heard, issues that will have life-altering impact in many cases. Thus, given the prosecution's strong desire for guilty pleas and the compelling issues available for negotiation, one would have expected a substantial proportion of ICTR defendants to have pled guilty. After Ruggiu, however, four-and-one-half years elapsed before another ICTR defendant pled guilty, and a number of ICTR defense counsel assert that few, if any, additional guilty pleas should be expected..$^{242}$ As the following discussion will reveal, that prediction stems from the fact that the key inducement offered to convince domestic defendants to plead guilty-a sentence reduction-has little persuasive value for ICTR defendants. Rather, these defendants place greater weight on a variety of primarily ideological factors that serve to discourage them from pleading guilty.

238. Telephone Interview with TH (Nov. 24, 2004); Telephone Interview with RQ (Dec. 1, 2004).

239. Telephone Interview with TH (Nov. 24, 2004).

240. Modestus Kessy, Genocide Suspects Call Off Protest, The Sunday Observer (U.K.), Sept. 26, 2004.

241. Thierry Cruvellier, Councillor Rutaganira Strikes a Good Deal, INT'L JUST. TRIB. (Paris, Fr.), Dec. 20, 2004.

242. Telephone Interview with MI (Dec. 2, 2004); Telephone Interview with PK (Nov. 23, 2004); Telephone Interview with RQ (Dec. 1, 2004). 
Indeed, most ICTR defendants have refused to plead guilty because they truly do not believe that they are guilty of the crimes for which they have been charged. ${ }^{243}$ It is widely accepted in the international legal community that the Rwandan massacres constituted a genocide, and every ICTR defendant convicted thus far has been convicted of some form of genocide. ${ }^{244}$ The great majority of ICTR defendants, however, steadfastly deny that genocide occurred in Rwanda, maintaining instead that the 1994 violence took place in the context of the long-running war between the Rwandan government and the RPF. ICTR defendants do not dispute that events spiraled out of control and that unfortunate and unnecessary violence was targeted against Tutsi civilians. But they maintain that this violence constituted the excesses of a legitimate and spontaneous national defense effort, not a genocidal plan to eliminate the Tutsi. ${ }^{245}$ They also stress that crimes were committed by both sides of the conflict. ${ }^{246}$ The ICTR has not prosecuted any members of the RPF, however, a fact which has exacerbated the defendants' belief that they are victims of victors' justice-that is, that they are being prosecuted only because their side lost the war-and that the Tribunal functions merely as a tool of the current Tutsi-led Rwandan government. Although most ICTR defendants are thus convinced that they cannot receive a fair trial, ${ }^{247}$ they see value in drawing out the proceedings and broadcasting their political views through those proceedings.

243. Telephone Interview with TH (Nov. 24, 2004); Telephone Interview with MI (Dec. 2, 2004); Telephone Interview with MK (Dec. 1, 2004); Telephone Interview with PK (Nov. 23, 2004); Telephone Interview with RQ (Dec. 1, 2004); see also MELVERN, supra note 153, at 3 ("The Arusha prisoners remain convinced of the rectitude of their actions.").

244. Prosecutor v. Gacumbitsi, Case No. ICTR-2001-64-T, Judgment, If 334 (June 17, 2004); Prosecutor v. Ntagerura et al., Case No. ICTR-99-46-T, Judgment and Sentence, ๆ 806 (Feb. 25, 2004); Prosecutor v. Kamuhanda, Case No. ICTR-95-54A-T, Judgment, If 750 (Jan. 22, 2004); Nahimana Judgment, supra note 185, ๆๆ 1092-1094; Prosecutor v. Kajelijeli, Case No. ICTR-98. 44A-T, Judgment and Sentence, If 942 (Dec. 1, 2003); Prosecutor v. Niyitegeka, Case No. ICTR96-14-T, Judgment and Sentence, If 480 (May 16, 2003); Prosecutor v. Semanza, Case No. ICTR97.20-T, Judgment and Sentence, If 553 (May 15, 2003); Prosecutor v. Elizaphan \& Gérard Ntakirutimana, Case Nos. ICTR-96-10 \& ICTR-96-17-T, Judgment and Sentence, II 877-78 (Feb. 21, 2003); Prosecutor v. Ndindabahizi, Case No. ICTR-2001-71-I, Judgment and Sentence, If 495 (July 15, 2001); Ruggiu Judgment, supra note 188, at Verdict; Prosecutor v. Musema, Case No. ICTR-96-13, Judgment and Sentence, Verdict (Jan. 27, 2000); Prosecutor v. Rutaganda, Case No. ICTR-96-3, Judgment and Sentence, Verdict (Dec. 6, 1999); Kayishema \& Ruzindana Judgment, supra note 183, at Verdict If 2; Serushago Sentence, supra note 174, at Verdict; Kambanda Judgment, supra note 154, at Verdict; Akayesu Judgment, supra note 166, at Verdict.

245. Telephone Interview with PK (Nov. 29, 2004).

246. Id.; Telephone Interview with MI (Dec. 2, 2004). Commentators estimate that, in putting an end to the killing spree, the Tutsi-led RPF killed tens of thousands of Hutu. Filip Reyntjens, Rwanda, Ten Years On: From Genocide to Dictatorship, 103 AFR. AFF. 177, 194 (2004).

247. Telephone Interview with WM (Oct. 19, 2005). 
The prosecution's recent attempts to secure guilty pleas have highlighted the ways in which the defendants' characterization of the violence and their role in that violence can shape and sometimes derail efforts to obtain guilty pleas. In at least one case, for instance, prosecutors and defense counsel were able to agree on a sentence recommendation-and a generous one at that, by all accounts-but were nonetheless unable to conclude a plea agreement because the defendant refused to plead guilty to charges of genocide.248 That the desire to avoid the label of génocidaire would be so compelling as to preclude an agreement, even when the prosecution agreed to the sentencing recommendation sought by the defendant, mystified the prosecutors with whom I spoke. ${ }^{249}$ Yet, the defendant's position is fully in keeping with the historical view of the conflict to which ICTR defendants subscribe. While an ICTR defendant may be able to justify to himself a guilty plea to crimes against humanity, since it is undisputed that massive violence did occur in 1994, he cannot admit to taking part in a genocide because doing so would be fundamentally at odds with the defendant community's long-held characterization of the violence. That the only guilty plea to be tendered in recent years-that of Rutaganira-required the prosecutor not just to withdraw the genocide count but to request Rutaganira's acquittal on that count only supports this view.

The legal characterization of crimes is typically of little significance to criminal defendants, whether domestic or international, unless that characterization bears directly on the defendant's expected sentence. That is, most criminal defendants do not particularly care whether they are convicted of this crime or that crime except in so far as the conviction affects the sentence. The high-ranking status of virtually all ICTR defendants helps to explain the atypical emphasis that these defendants place on characterization issues. While the ICTY has tried both high-level architects of the atrocities and low-level, hands-on killers, and the Special Panels have prosecuted only low-level, uneducated offenders, the vast majority of ICTR defendants held prominent positions in Rwandan public life. Because most ICTR defendants had been senior politicians, military leaders, or influential business people, they possess far greater concern than would lowerranking defendants about the legal and factual characterization of the conflict. In particular, they ardently seek to promote a narrative that defends and enhances their historical legacy. One defense counsel

248. Telephone Interview with TH (Nov. 24, 2004); Telephone Interview with MI (Dec. 2, 2004); Telephone Interview with RQ (Dec. 1, 2004).

249. Telephone Interview with TH (Nov. 24, 2004). 
reported, for instance, that his client's primary goal during his trial was to impeach prosecution witnesses whom he believed to be lying and to present the testimony of witnesses who could reveal to the world what he believed was the true nature of the events of 1994. The prospect of spending the rest of his life behind bars was, his counsel believes, of less concern to this defendant than was his opportunity to create through his trial a historical record that might, even many years from now, vindicate his view of the conflict. ${ }^{250}$ For these reasons, it should come as no surprise that three of the four ICTR defendants who pled guilty held low-level positions ${ }^{251}$ and consequently had no Iegacy in need of protecting.

The defendants' commitment to their characterization of the violence, in addition, has been reinforced during the several years that most ICTR defendants have been imprisoned. Before and during trial, ICTR defendants are detained in the United Nations Detention Facility ("UNDF") in Arusha, Tanzania. By all accounts, the defendants have formed a closely-knit, hierarchically-ordered community that communicates regularly, engages in joint decisionmaking, ${ }^{252}$ and mirrors in many ways the characteristics of the Rwandan administrative state. In such a community, defendants do not have the benefit of hearing views contrary to their own; thus, their own beliefs become even more entrenched. ${ }^{253}$ Further, those most responsible for the 1994 violence are said to wield the greatest power within the detainee community. ${ }^{254}$ Rwandan society is said by many to be characterized by an "unconditional obedience to authority," 255 so that the leaders of the detainee community have considerable ability to suppress views that are inconsistent with prevailing understandings. Defendants are additionally deterred from pleading guilty because admitting genocide undermines the legal position of their fellow detainees. Group loyalty, then, discourages defendants from taking this step, and so does fear. The families of many ICTR defendants live in

250. Telephone Interview with RQ (Dec. 1, 2004).

251. Rutaganira, in addition, likely also had less formal education than most of the remaining ICTR defendants. Many of the latter are bi- or tri-lingual, while Rutaganira speaks only Kinyarwanda. Prosecutor v. Rutaganira, Case No. ICTR-95-1C-I, Minutes of Proceedings at I 1.a. (Mar. 7, 2002)

252. Ruggiu Transcript, supra note 188 , at $48-49$.

253. Telephone Interview with TH (Nov. 24, 2004); Telephone Interview with MI (Dec. 2, 2004).

254. Telephone Interview with MI (Dec. 2, 2004); Telephone Interview with MK (Dec. 1, 2004); MELVERN, supra note 153, at 3.

255. PRUNIER, supra note 145, at 141. But see Lars Waldorf, Mass Justice for Mass Atrocity, Rethinking Local Justice as Transitional Justice, 79 TEMPLE L. REV. (forthcoming 2006) (calling the authoritarian thesis into question, by for instance, pointing to "instances of disobedience and resistance to state authority under a succession of regimes"). 
Hutu communities in various nations, and some defendants legitimately fear that their families will suffer retaliation if they plead guilty. ${ }^{256}$

While a fundamental dispute about the nature of the 1994 events stands as the primary factor deterring ICTR defendants from pleading guilty, there exist other, perhaps less influential, reasons for the dearth of guilty pleas. First among these relates to ICTR defense counsel and the advice they give to their clients. Speculation exists, for instance, that some defense counsel, particularly those from developing nations, may be less inclined to encourage their clients to plead guilty even when the clients would benefit from doing so, because counsel themselves have financial incentives to proceed to trial. ${ }^{257}$ While many Western counsel earn less at the ICTR than they would in their home countries, counsel from developing nations typically earn considerably more at the ICTR than they would at home. A conflict-of-interest can arise, therefore, between counsel, who have a financial interest in prolonging their ICTR representation, and their clients, who may benefit from pleading guilty. Other ICTR defense counsel strongly identify with their clients' political views and with their understanding of the events of 1994. These counsel are as convinced of their clients' innocence as the clients themselves and typically discourage guilty pleas, considering them unprincipled capitulations.

For some ICTR defendants, health and life expectancy considerations also serve to diminish the influence of sentencing discounts. A number of ICTR defendants are reportedly infected with HIV. ${ }^{258}$ These defendants may conclude that their life expectancies are already so reduced that the prosecution's sentencing concessions will ultimately have no practical effect on the amount of time that they spend incarcerated. That is, these defendants might reason that, if convicted, they will die behind bars no matter what sentence they receive, so they might as well try for an acquittal. Guilty pleas may be undesirable in addition because they hasten the defendants' conviction and their subsequent transfer from the UNDF to the prison in which they will ultimately serve their sentences. The UNDF is a comfortable detention facility by African standards and one that provides its detainees with appropriate medical treatment. By contrast, the Magistrat of the Direction National de l'Administration Penitentiaire

256. Telephone Interview with WM (Oct. 19, 2005).

257. Telephone Interview with MI (Dec. 2, 2004); Telephone Interview with MK (Dec. 1, 2004).

258. Telephone Interview with TH (Nov. 24, 2004); Telephone Interview with MK (Dec. 1, 2004); Interview with BM, in The Hague, Neth. (Nov. 8, 2004); Telephone Interview with RQ (Dec. 1, 2004). 
et de l'Education Surveillee in Mali reported that while ICTR convicts serving their sentences in Mali receive some medication for "transmissible diseases," the amounts available are insufficient. ${ }^{259}$ Thus, to the extent that an ICTR defendant considers that even after a guilty plea he will still serve a lengthy sentence, he may choose to maximize the portion of that sentence that he serves at the UNDF. A final factor deterring ICTR defendants from pleading guilty stems from the legacy of distrust generated by the Kambanda case. Whether accurate or not, the prevailing belief amongst ICTR defendants is that Kambanda was misled into pleading guilty. Consequently, some ICTR defendants have remained skeptical that the prosecution's promises are made in good faith. ${ }^{260}$

The foregoing discussion, then, places the earlier analysis of the ICTR's guilty pleas in a new light. The earlier discussion traced the evolution that has occurred in the ICTR's willingness to reward guilty pleas with sentencing discounts, and it observed that, on the surface, that evolution suggested that the ICTR should expect to receive a substantial number of gnilty pleas. Having now delineated the other factors that have proven more influential than sentence discounts to ICTR defendants, the guilty pleas tendered thus far appear to be best understood as the products of unique circumstances that are unlikely to be replicated. Kambanda, for instance, pled guilty expecting to receive an extremely short sentence. Kambanda's counsel argued for a maximum term of two years' imprisonment, ${ }^{261}$ and Kambanda apparently believed that he was likely to receive such a sentence. No ICTR defendant since Kambanda could be so mistaken.

Serushago's and Ruggiu's guilty pleas likewise stemmed from unusual circumstances that are unlikely to be repeated at the ICTR. Serushago was a low-level offender whose case never would have come before the ICTR had Serushago himself not placed it there. Because he had no leadership role, Serushago could plead guilty without concern for the historical effect of his plea.

259. Telephone Interview with Ahmadou Tourre (Sept. 13, 2005). Medication is generally scarce in Malian prisons. See E.V.O. Dankwa, African Comm'n ON Human \& PEOPLe's Rights, Series IV, No. 4, Mali Prisons Revisited: Report of the SPECIAl. RapPorteur on PRISONS AND CONDITIONS OF DETENTION IN AFRICA 16-18 (1999). At least one women's prison in Bamako releases prisoners with HIV because they "simply don't have the means to provide care and treatment for them." Julia Nogushi, HIV Management in a Malian Women's Prison, BRUNAP NEws (Brown Univ. AlDS Program, Providence, RI), Spring 2004, at 16.

260. Telephone Interview with MI (Dec. 2, 2004); Telephone Interview with PK (Nov. 23, 2004). In addition, high-level defendants might fear that the Trial Chamber's apparent practice of discounting sentences following guilty pleas might apply only to low-level offenders such as Serushago and Ruggiu.

261. Prosecutor v. Kambanda, Case No. ICTR-97-23-1, Transcript at 33 (Sept. 3, 1998). 
Ruggiu's guilty plea was likewise uncomplicated by many of the factors deterring the remaining ICTR defendants from pleading guilty. Although, as an initial matter, Ruggiu clung to the Hutu's characterization of the violence, as a Belgian who had emigrated to Rwanda only four months before the massacres began, Ruggiu did not experience the ethnic overtones of the conflict or the subsequent selective prosecutions in the way that other ICTR defendants do. In addition, even though Ruggiu hails from a civil-law country in which plea bargaining is not prevalent, ${ }^{262}$ as a European, he was likely more receptive to the lure of a sentence discount than his community-minded Rwandan co-defendants. Ruggiu's guilty plea is difficult to interpret in part because Ruggiu himself is difficult to understand. A close friend testifying on his behalf described him as excessively rule-oriented and hard to get along with; even his lawyer described him as "not a particularly easy character in his person."263 Moreover, the prosecution has received little benefit from his testimony or the information he provided. Ruggiu admitted to lying to prosecutors in his early interviews, ${ }^{264}$ and his testimony against his former co-defendants was so riddled with inconsistencies that the Trial Chamber rejected it "in its entirety."265 Ruggiu's guilty plea cannot, then, be seen to presage much of anything since it may have sprung from the same idealism and impulsiveness that apparently motivated Ruggiu's relocation to Rwanda in the first place.

Before Rutaganira pled guilty in December 2004, a number of ICTR defense counsel whom I interviewed predicted that, as a result of the many factors canvassed above, the ICTR would not receive any further guilty pleas. ${ }^{266}$ Although Rutaganira's guilty plea renders that prediction technically inaccurate, the reasons underlying the prediction remain compelling. Because Rutaganira held a low-ranking position in the Rwandan political hierarchy, many of the factors that act to discourage more senior ICTR defendants from pleading guilty had less relevance for him. Further, the prosecution had the ability to offer Rutaganira benefits in addition to a lenient sentence recommendation. Because he was a low-level offender, Rutaganira was just the sort of

262. See Christine Van den Wyngaert, Belgium, in Criminal Procedure Systems IN THE EUROPEAN COMMUNITY 1, 42 (Christine Van den Wyngaert et al. eds., 1993) ("The Belgian system does not know the plea of guilty, and concomitantly, the concept of plea bargaining is unknown.").

263. Ruggiu Transcript, supra note 188 , at $49,146-47$.

264. Nahimana Judgment, supra note 179, ๆ 549; Convicted Ex-Radio, supra note 264.

265. Nahimana Judgment, supra note 179 , ๆๆ 548-49.

266. Telephone Interview with MI (Dec. 2, 2004); Telephone Interview with RQ (Dec. 1, 2004). 
defendant whose case was apt to be transferred to Rwanda. Thus, the prosecution had that bargaining chip at its disposal, and it was willing, in addition, to seek a favorable detention location for Rutaganira. Most importantly, Rutaganira's plea agreement required him to admit only that a massacre took place that he failed to prevent, and that is an admission that even the most intractable ICTR defendant could likely make. ICTR prosecutors cannot be satisfied by such minimal admissions in other cases, and it remains to be seen whether the desire to avoid a trial in Rwanda will provide sufficient motivation to persuade other defendants whose cases might be transferred to Rwanda to plead guilty. It certainly may. ICTR defendants are reportedly terrified of the physical violence they believe they will suffer in Rwanda, 267 and even if they escape such harm, if convicted, they can look forward only to an unpleasant detention in an over-crowded Rwandan prison that may not adequately provide for their medical needs. ${ }^{268}$ One defense counsel went so far as to describe a transfer to Rwanda as a death sentence. 269 In addition, because a trial in a Rwandan court is not apt to provide defendants with as desirable a public platform to proclaim their version of the events of 1994 as an ICTR trial, the perceived value of trials will diminish. The question of whether it is ethically appropriate to bargain over issues of such potential significance as the transfer of cases to Rwandan courts is beyond the scope of this Article, but, ethical or not, such bargaining likely provides prosecutors with the best vehicle for convincing future ICTR defendants to plead guilty.

\section{Cultural Factors Influencing Plea Bargaining AND the PERCEPTION GAP BETWEEN DEFENDANTS AND THEIR COUNSEL: GUILTY Pleas at THe Special PANELS For SERIOUS CRIMES}

East Timor had been a Portuguese colony for more than 450 years 270 when, in 1974, Portugal began to consider dismantling its colonies. Before Portugal could take any action, however, Indonesia

267. Telephone Interview with MI (Dec. 2, 2004); Telephone Interview with MK (Dec. 1, 2004); Telephone Interview with PK (Nov. 23, 2004); Telephone Interview with RQ (Dec. 1, 2004). Others believe that, because cases that the ICTR transfers to Rwanda will be carefully watched, ICTR defendants are relatively unlikely to suffer physical violence. Telephone Interview with WM (Oct. 19, 2005).

268. For an indictment of ICTR prison conditions in the late 1990s, see Human Rights First, Prosecuting Genocide in Rwanda: A Human Rights First Report on the ICTR and National Trials, VIII.E. (July 1997); Drumbl, supra note 193, at 571-72.

269. Telephone Interview with MI (Dec. 2, 2004).

270. For a discussion of the Timorese colonial period, see James J. Fox, Tracing the Path, Recounting the Path: Historical Perspectives on Timor, in OUT OF THE ASHES: DESTRUCTION AND RECONSTRUCTION OF EAST TIMOR 1, 1 (James J. Fox \& Dionísio Babo-Soares eds., 2003). 
invaded East Timor in December 1975 and soon after formally annexed the territory, proclaiming East Timor to be Indonesia's twenty-seventh province. ${ }^{271}$ By 1999, Indonesia's continued military presence in East Timor had led to trenchant international criticism and a financial drain on Indonesia's fragile economy. ${ }^{272}$ As a consequence, then-Indonesian President B.J. Habibie committed to a UN-sponsored consultation process whereby a referendum would be held permitting the East Timorese to vote either to become independent or to remain within Indonesia, bearing a special autonomous status. ${ }^{273}$ The months leading up to the August 1999 ballot saw considerable violence, sponsored by Indonesia and aimed at intimidating the East Timorese population into voting to remain within Indonesia. ${ }^{274}$ When 78.5 percent of the East Timorese voted instead for independence, ${ }^{275}$ heavily armed groups conducted a "scorched earth" campaign. These groups "burned and looted entire towns and villages, attacked and killed at random in the streets, and forcibly 'evacuated' or kidnapped people to the western half of the

271. Int'l Comm'n of Inquiry on East Timor, Report of the International Commission of Inquiry on East Timor to the Secretary-General, If 5, delivered to the Secretary-General, U.N. Doc. A/54/726, S/2000/59 (Jan. 31, 2000) [hereinafter Commission of Inquiry on East Timor]; see also Phillip J. Curtin, Comment, Genocide in East Timor? Calling for an International Criminal Tribunal for East Timor in Light of Akayesu, 19 DICK. J. INT'L L. 181, 184-85 (2000) (discussing the colonial history and Indonesia's invasion of East Timor); Sylvia de Bertodano, Current Developments in Internationalized Courts, 1 J. INT'L CRIM. JUST. 226, 228-29 (2003) (providing a historical background on East Timor).

272. The financial issues stemmed in part from the monetary crisis in South-East Asia, which rendered Indonesia particularly reliant on International Monetary Fund restructuring loans and particularly vulnerable to international criticism that might endanger the provision of those loans. See Grayson J. Lloyd, The Diplomacy on East Timor: Indonesia, the United Nations and the International Community, in OUT OF THE ASHES, supra note 270, at 79, 8-85 (discussing the influence of international pressure and IMF loans on the Indonesian government's concessions regarding East Timorese autonomy).

273. Suzannah Linton, Rising from the Ashes: The Creation of a Viable Criminal Justice System in East Timor, 25 MELBourne U. L. REv. 122, 128-29 (2001); see also Dionísio BaboSoares, Political Developments Leading to the Referendum, in OUT OF THE ASHES, supra note 271, at 57, 64-66 (discussing the political and military events leading up to the referendum). See generally Lloyd, supra note 272, at 84-92.

274. See Commission of Inquiry on East Timor, supra note 271, ๆ1 41-42, 124 (discussing the tactics used to intimidate East Timorese civilians); The Secretary-General, Situation of Human Rights in East Timor: Note by the Secretary-General, I 26, U.N. Doc A/54/660 (Dec. 10, 1999) (" $[\mathrm{P}]$ ro-integration groups launched a campaign of intimidation and violence directed against persons and communities known for their pro-independence sympathies.").

275. Suzannah Linton, Cambodia, East Timor and Sierra Leone: Experiments in International Justice, 12 CRIM. L. F. 185, 203 (2001). Voter turnout was extremely high: $98.6 \%$ of registered voters cast their ballots. Fausto Belo Ximenes, The Unique Contribution of the Community-Based Reconciliation Process in East Timor 7 (May 28, 2004) (unpublished paper, on file with author). 
island, which was still part of Indonesia."276 After sending security forces to halt the violence, the Security Council adopted Resolution 1272, establishing the United Nations Transitional Administration in East Timor and empowering it "to exercise all legislative and executive authority, including the administration of justice."277 Pursuant to that authority, the Secretary-General for East Timor created Special Panels for Serious Crimes in the Dili District Court to prosecute genocide, war crimes, crimes against humanity, and particularly serious domestic crimes. ${ }^{278}$ Although the success of the Special Panels was substantially impeded by Indonesia's refusal to surrender suspects, ${ }^{279}$ the Special Panels were able to prosecute

276. Hansjörg Strohmeyer, Collapse and Reconstruction of a Judicial System: The United Nations Missions in Kosovo and East Timor, 95 AM. J. INT'L L. 46, 50 (2001); see also Suzannah Linton, Cambodia, East Timor and Sierra Leone: Experiments in International Justice, 12 CRIM. L. F. 186, 202-03 (2001); Priscilla B. HAYNer, UNSPEAKable TruTHS: FACING The Challenge OF TRUTH COMMISSIONS 261 (2002).

277. S.C. Res. 1272, U.N. Doc. S/RES/1272 (Oct. 25, 1999).

278. UNTAET Reg. No. 2000/11, §§ 9-10, UNTAET/REG/2001/11 (Mar. 6, 2000); UNTAET Reg. No. 2000/15, § 1.3, UNTAET/REG/2000/15 (June 6, 2000). The domestic crimes over which the Dili District Court has jurisdiction are murder, sexual offenses, and torture. UNTAET Reg. No. 2000/11, supra, § 10.1. The Special Panels were internationally dominated: they were composed of two international judges and one East Timorese judge, and the Court of Appeal hearing cases involving serious crimes had a panel with two out of three international judges. UNTAET Reg. No. 2000/15, supra, § 22. Since East Timor gained independence in May 2002, the Serious Crimes Unit, which was the prosecutorial arm of the Special Panels, worked under the legal authority of the Prosecutor-General in Timor-Leste, the name taken by East Timor on independence. Judicial System Monitoring Programme, The Lolotoe Case: A Small SteP FORWARD, 3 (July 2004) [hereinafter THE Lolotoe CASE: A SMALl STEP FoRWARd].

279. By December 2004, the Special Panels had indicted 370 individuals. Press Release, Office of the Deputy Gen. Prosecutor for Serious Crimes Timor Leste, SCU Indicts Suai Church Massacre Commanders (Nov. 30, 2004). At least 281 of those individuals were residing in Indonesia, Judiclal System Monitoring Programme, The Future of the Serious Crimes UNIT: JSMP ISSUE REPORT 10 (Jan. 2004), and that country refused to surrender them. See id.; Amnesty InT'L \& Judicial System Monitoring Programme, Justice For TimoR-Leste: The WAY FORWARD § 4.1 at 23 (Apr. 2004) [hereinafter JUSTICE FOR TIMOR-LESTE] ("The Indonesian government has publicly stated that it will not cooperate with the Timor-Leste government in bringing to trial persons against whom indictments have been presented to the Special Panels."); ASIA PACIFIC CENTRE FOR MILITARY LAW \& JUdicial System MONITORING PROGRAMme, RePORT of Proceedings: Symposium on Justice for InTERnational CRimes CommitTed ON THE TERRITORY OF EAST TIMOR $§ 3.1$ at 5 (Jan. 2003) ("Thus far, there has been no cooperation from Indonesia with requests for the detention and transfer of indictees within Indonesia.").

In an effort to stave off calls for an international criminal tribunal for East Timor on the order of the ICTY and ICTR, the Government of Indonesia agreed to undertake domestic prosecutions of Indonesians accused of international crimes relating to Timorese independence. These trials have recently concluded and have been condemned as shams. Indonesia selected only five incidents out of 670 for prosecution, and the prosecutions themselves were plagued by corruption, incompetence, and an effort to shield perpetrators from responsibility. See JUSTICE FOR TIMOR-LESTE, supra, $\S \S 5$ 5 (providing a history of the Indonesian trials); William J. Furney, East Timor Atrocities: Submit to International Tribunal, THE STRAITS TIMES (Singapore), Aug. 15, 2003 (reporting that "almost every major international human rights group slamm[ed] the trials of 18 former officials as an unabashed 'whitewash."); Eugene Bingham, Getting Away with 
eighty-seven defendants, convicting eighty-four of them. In May 2005, the UN stopped funding the Panels and they consequently closed. 280

Details of Special Panels prosecutions are extremely difficult to obtain. ${ }^{281}$ Some judgments are not available in English, and some that are available in English are limited to three or four page "Dispositions of the Decision," which do little more than state the defendants' crimes and the sentences imposed for those crimes. ${ }^{282}$ Special Panels cases are therefore challenging to research, ${ }^{283}$ but prosecutors and defense counsel indicate that at least 50 percent of Special Panels defendants elected to plead guilty. ${ }^{284}$ The proportion of

Murder, NEW ZEALAND HERALD, Aug. 30, 2003 (reporting on the corruption and non-cooperation of the Indonesian government during the trials); David Cohen, Seeking Justice on the Cheap: Is the East Timor Tribunal Really a Model for the Future?, ASIA PACIFIC IssuEs (East-West Center, Honolulu, HI), Aug. 2002, at 4 (discussing Indonesia's "show trials"). Twelve of the eighteen defendants were acquitted outright, and four of the six who were convicted were sentenced to terms of three years' imprisonment for crimes against humanity. All of the defendants remained free while their cases were on appeal, JUSTICE FOR TIMOR-LESTE, supra, $\$ 9.9$ at 48, and in 2004, Indonesia's appeals court overturned four of the six convictions which concerned Indonesian defendants and halved the sentences of the remaining two defendants, hoth of whom are ethnic Timorese. Andrew Burrell, Just Two Punished for Timor Atrocities, AUSTRALIAN Fin. REview, Aug. 7, 2004; Jakarta Rejects Timor Convictions, BBC NEws, Aug. 6, 2004. Following dissatisfaction with these prosecutions, UN Secretary-General Kofi Annan established a Commission of Experts to examine and report on the prosecutions. Annan Names Experts to Probe Impunity in Independence Violence in Timor-Leste, U.N. NEWS SERV., Feb. 18, 2005. The Commission's report recommends requiring Indonesia to review the prosecutions and to re-open them if appropriate. It also recommends giving Indonesia six months to provide a comprehensive report to the UN Secretary-General concerning its investigations of its own prosecutions and the indictments issued by the Serious Crimes Unit. The Secretary-General, Annex 1: Summary of the Report to the Secretary-General of the Commission of Experts to Review the Prosecution of Serious Violations of Human Rights in Timor-Leste (then East Timor) in 1999, IT 25, 27-28, delivered to the Security Council, U.N. Doc. S/2005/455 (May 26, 2005). If Indonesia fails to undertake this investigation, the Commission recommended that the UN Security Council establish an ad-hoc criminal tribunal for Timor-Leste. Id. If 29.

280. Judicial System Monitoring Programme, Special Panels for Serious Crimes, available at http://www.jsmp.minihuh.org/Court\%20Nionitoring/spsc.htm; Human Rights Watch, Human Rights Overview: East Timor, available at http:/hrw.org/english/docs/2005/01/13/eastti9825.htm.

281. The best source for information on the Special Panels is the website of the Judicial System Monitoring Programme (JSMP), http://www.jsmp.minihub.org.

282. E.g., Prosecutor v. Mendes Correia, Dili District Court, Special Panels for Serious Crimes, Dispositions, Case No. 19/2001 (Mar. 3, 2004); Prosecutor v. Sarmento, Dili District Court, Special Panels for Serious Crimes, Case No. 18/2001, Disposition, (July 16, 2003); Prosecutor v. Mendonça, Dili District Court, Special Panels for Serious Crimes, Case No. 18a/2001, Disposition of the Decision (Oct. 13, 2003).

283. In January 2005, the President of the Court of Appeal issued instructions that all information in case files, including final decisions, would no longer be publicly available. Press Release, Judicial System Monitoring Programme, Public Access Barred to Decisions from District Courts (Jan. 25, 2005) (on file with author). Decisions such as these certainly do not enhance the already limited transparency of the Panels.

284. Telephone interview with Nicholas Koumjian, Deputy Prosecutor for Serious Crimes, Special Panels for Serious Crimes (July 29, 2004); Telephone interview with Alan Gutman, Def. Counsel, Special Panels for Serious Crimes (July 30, 2004). 
defendants who pled guilty is thus much higher at the Special Panels than it is at the ICTY or the ICTR, and that high proportion does bear a significant relationship to the sentencing discounts bestowed on Special Panels defendants who entered guilty pleas. The relationship, however, is a complex one. Special Panels defendants themselves were little tempted by the prospect of sentence discounts. Instead, they were motivated to plead guilty by a coalition of cultural and socio-economic factors that not only play little role in the guilty-plea decisions of Western defendants but may be difficult for Westerners even to comprehend. Indeed, for a variety of reasons that will soon be canvassed, many Special Panels defendants would have pled guilty even if they had not obtained any sentencing benefits in exchange. Special Panels defendants are represented by counsel, however, and in the last years of the Panels' existence, counsel insisted that their clients receive appropriate discounts before they would enter guilty pleas. ${ }^{285}$ Thus, sentencing discounts came to be required if East Timorese defendants were to tender guilty pleas, but it was not typically the East Timorese defendants who required them. The next Section will examine why the prospect of sentence discounts did not substantially influence the guilty-plea decisions of Special Panels defendants, and the following Section will explore the way in which the presence of defense counsel served to transform sentence discounts from an incidental benefit to the primary goal of defendants' guilty pleas.

\section{A. Sentencing Discounts Through the Eyes of Special Panels Defendants}

In the early days of the Special Panels, no plea negotiations took place. ${ }^{286}$ The prosecution saw no pressing need to resolve its cases summarily, and defense counsel at that time were so few, so under-resourced, and so unfamiliar with guilty pleas that they were not truly capable of engaging in plea negotiations. ${ }^{287}$ In addition,

285. In the Lolotoe case, for instance, when defendant José Cardoso spontaneously attempted to apologize to the court, defense counsel immediately stopped Cardoso from speaking and asked to confer with him. After that conference, Cardoso asserted that he no longer wished to say anything. Judicial System Monitoring Programme, The Lolotoe Case, Trial Notes (Apr. 10, 2002) (unpublished document, on file with author).

286. Telephone interview with Essa Faal, former Chief of Prosecutions, Special Panels for Serious Crimes (July 30, 2004); Telephone interview with Stuart Alford, former prosecutor, Special Panels for Serious Crimes (Feb. 17, 2005); Telephone interview with Brenda Sue Thornton, former prosecutor, Special Panels for Serious Crimes, (Sept. 12, 2005).

287. Telephone interview with Brenda Sue Thornton, former prosecutor, Special Panels for Serious Crimes (Sept. 12, 2005). 
neither the prosecution nor the defense knew what range of sentences the Special Panels would be inclined to impose, so bargaining over sentencing recommendations seemed a particularly uncertain endeavor. ${ }^{288}$ However, despite the fact that early Special Panels defendants received no promise of a sentence discount, virtually all of them admitted to participating in the crimes for which they were charged, and many formally attempted to plead guilty. ${ }^{289}$ The prospect of a sentence reduction was obviously not the factor motivating these early Special Panels defendants to plead guilty. Rather, the primary explanation for the defendants' propensity to spontaneously confess their crimes rests on the East Timorese belief system and, more particularly, on the Timorese understanding of crime and the proper response to crime.

Special Panels defendants subscribe to a world-view that is very different from that of Westerners, and one that is much less likely to value the sentencing concessions that prove so important to ICTY defendants and defendants in Western criminal justice systems. ${ }^{290}$ The majority of East Timorese survive by means of subsistence farming and believe that, to ensure appropriate weather

288. Telephone interview with Stuart Alford, former prosecutor, Special Panels for Serious Crimes (Feb. 17, 2005).

289. See, e.g., Prosecutor v. Fernandes, Dili District Court, Special Panels for Serious Crimes, Case No. 02 C.G. 2000, 4 (Mar. 1, 2000) ("The Defence admitted that Julio Fernandes stabbed twice Americo, that the victim was tied, beaten and suffering and that the crowd was shouting "kill him, kill him."); Prosecutor v. Soares Carmona, Dili District Court, Special Panels for Serious Crimes, Case No. 03 C.G. 2000, Judgment, 3 (Mar. 8-Apr. 25, 2001) ("Most of the factual allegations made by the Public Prosecutor are undisputed because Carlos Soares Carmona himself acknowledged them."); Prosecutor v. Bere, Dili District Court, Special Panels for Serious Crimes, Case No. 10/2000, Judgment, 5 (May 15, 2001) ("Most of the factual allegations made by the Public Prosecutor are undisputed because Manuel Gonçalves Leto Bere himself acknowledged them."); Prosecutor v. Soares, Dili District Court, Special Panels for Serious Crimes, Case No. 12/2000, 4 (May 31, 2001) ("The accused admits that he shot the victim ... "); Prosecutor v. Leki, Dili District Court, Special Panels for Serious Crimes, Case No. 05/2000, Judgment, 2 (June 11, 2001) ("The defendant did not plead guilty. He stated at the time he was forced to kill only one of the alleged victims, and consequently was not guilty."); Prosecutor v. Valente, Dili District Court, Special Panels for Serious Crimes, Case No. 3/2001, 2 (June 19, 2001) (reporting that the defendant "recognizes that he killed Benedito Marques Cabral, but [says] that he was ordered.").

290. Belief systems vary from region to region in East Timor. See David Mearns, Looking Both Ways: Models for Justice in East Timor, AUSTRALIAN LEGAL RESOURCES INTERNATIONAL PUBLICATION, at 32 (Nov. 2002) (stating that underlying principles of justice and social interaction exist "despite [the villagers'] relative autonomy and apparent differences in detail.") (on file with author); Tanja Hohe \& Rod Nixon, Reconciling Justice: 'Traditional' Law and State Judiciary in East Timor, paper prepared for the United States Institute of Peace and delivered at tbe workshop on the Working of Non-State Justice Systems, held at the Overseas Development Institute, Brighton U.K., at 12-13 (Mar. 6.7, 2003) (on file with author); Fox, supra note 270 , at 1 . I have space to present only a bare-bones summary of selected beliefs that are common to most regions and that are relevant to my discussion. 
conditions, soil fertility, and the like, they must maintain excellent relations with their ancestors. ${ }^{291}$ Maintaining these relations requires East Timorese to perform certain rituals, adhere to certain taboos, and maintain hierarchical social relationships. It is only through these practices, the East Timorese believe, that they will appease their ancestors and prevent misfortune. ${ }^{292}$ Indeed, as one scholar put it, the East Timorese "would be afraid not to follow their customs, as it could prove very dangerous to them and their families not to do so. The idea that mystical sanctions are likely to be imposed by the ancestors or the spirits remains a very strong force."293

The need to appease powerful ancestral spirits also informs the East Timorese understanding of crime and its appropriate punishment. ${ }^{294}$ The East Timorese view crimes and other transgressions of the social order as disruptions of the cosmic flow of values. Because crime creates an imbalance of values, the appropriate response to crime must aim to restore that balance, which will in turn reinforce the socio-cosmic order. ${ }^{295}$ Such a restoration requires reconciliation between affected individuals and their communities, and to achieve that reconciliation, offenders are typically required to acknowledge their wrongdoing publicly, to apologize, and to obtain the victim's forgiveness. ${ }^{296}$ A successful reconciliation signifies that the conflict has been resolved and that both sides are again engaged in a peaceful relationship; if reconciliation fails to occur, by contrast, East Timorese believe that the social order remains imbalanced and the community's well-being subject to threat.

The desirability-indeed, the compelling need-in the East Timorese belief system for reconciliation motivated most Special Panels defendants to confess their wrongdoing regardless of whether sentencing concessions were promised them in return for their

291. Hohe \& Nixon, supra note 290 , at 11.

292. Id.

293. Mearns, supra note 290, at 44-45; see also Dionísio Babo-Soares, Nahe Biti: The Philosophy and Process of Grassroots Reconciliation (and Justice) in East Timor, 5 ASIA PACIFIC J. ANTHROPOLOGY 15, 22 (2004) ("Failure to observe appropriate rituals/exchanges leads to an imbalance, which might result in negative consequences to those living in the secular world.").

294. Indeed, "[a]ll socio-cultural aspects of 'traditional' society are interdependent. Any one aspect, such as law, kinship or the belief system cannot be extracted from the entire socio-cosmic system without taking it out of context." Hohe \& Nixon, supra note 290 , at 12.

295. Id. at 18.

296. United Nations Development Programme, The Community Reconciliation PROCESS OF THE COMMISSION FOR RECEPTION, TRUTH AND RECONCILIATION 26-27 (April 2004) (on file with author) [hereinafter UNDP REPORT ON THE COMMUNITY RECONCILIATION PROCESS]; see also Babo-Soares, supra note 293, at 15-16 (observing that the East Timorese conception of reconciliation "forms part of a grand process that aims to link the past and the future" and is an evolving process which seeks ultimately to achieve a stable social order within society). 
confessions. Special Panels defendants wanted to return to their original communities after suffering whatever punishment the Special Panels chose to mete out, but they knew that they would not be welcomed back unless they had reconciled with their victims. To accomplish this, the defendants needed to suffer the punishment prescribed by the Special Panels. Although the following discussion will reveal that Special Panels defendants have little understanding of the contours of the crimes with which they were charged, they do possess a basic understanding that their actions were wrong, and that their wrongdoing must give rise to punishment. 297 Confessing their crimes serves to acknowledge their wrongdoing and constitutes the first step in the reconciliation process.

Sentencing discounts provided only a weak inducement to Special Panels defendants in addition because East Timorese view incarceration as an alien form of punishment and do not seek to avoid it with quite the same urgency as Western defendants. Because crime is conceived as creating an imbalance of values, traditional East Timorese justice mechanisms do not seek primarily to punish the offender, but aim rather to restore values and to re-establish the sociocosmic order. ${ }^{298}$ To that end, traditional East Timorese justice requires first and foremost that the offender compensate the victim and the victim's family, whose honor has been damaged, as a means of re-establishing balance. ${ }^{299}$ In cases of theft, for instance, the offender is required to compensate the victim for the stolen goods and to pay additional compensation. If a house is destroyed, the perpetrator must compensate the victims for everything that was in the house or, if he is unable to do so, the victims are entitled to the perpetrator's belongings. 300 Even a murder may result in compensation being paid by the murderer to the victim's family. ${ }^{301}$ Because compensation and reconciliation constitute the central features in the East Timorese

297. Telephone interview with Sylvia de Bertodano, former Defense Counsel, Special Panels for Serious Crimes (Dec. 2, 2004). Indeed, one defense counsel asserted that Special Panels defendants often talk of "killing" in an imprecise way. If a defendant, for instance, draws the blood of a victim who then falls to the ground, he might feel that he has "killed" that victim even though subsequent questioning reveals that the victim later got up and was killed by other militia members. Email interview with Sebastian Appenah, Defense Researcher/Lawyer, Special Panels Defence Lawyers Unit (Dec. 6, 2004).

298. Hohe \& Nixon, supra note 290 , at 18.

299. Mearns, supra note 290 , at 43 ; see also id. at 54 ("[T] area of justice and dispute resolution are all built upon a fundamental principle of reciprocity and fair compensation."); UNDP REPORT ON THE COMMUNITY RECONCILIATION PROCESS, supra note 296, at 1I, 28 ("[J]ustice in East Timor [is] not always about punishment, but also compensation, contrition and other forms of reciprocity.").

300. Hohe \& Nixon, supra note 290 , at 21.

301. Id. at 20 . 
conception of justice, detention is rarely imposed on offenders. Indeed, in the eyes of many East Timorese, detention constitutes precious little punishment since prisoners are fed and housed in jail, and in some cases can avoid their compensation obligation. ${ }^{302}$ I do not mean to suggest that Special Panels defendants find incarceration appealing, but in light of the difficulties inherent in eking out a sustainable existence in East Timor, Special Panels defendants do not appear to view incarceration with quite the same distaste as do criminal defendants from more prosperous nations. Consequently, a promise to reduce the sentence of incarceration is not apt to be valued as highly by Special Panels defendants.

Finally, sentencing discounts did little to influence the guiltyplea decisions of Special Panels defendants because these defendants had only a limited ability to understand the nature of the guilty-plea process or even the larger prosecution surrounding it. The Special Panels were not able to obtain custody over high-level offenders, ${ }^{303}$ so virtually all of the defendants brought before the Panels were illiterate farmers, ${ }^{304}$ many of whom were coerced into participating in the atrocities. In addition to lacking general education, these defendants lacked specific understanding of the nature of criminal processes. During the twenty-four years that Indonesia occupied East Timor, the East Timorese were completely excluded from judicial processes. Consequently, East Timorese have had "no experience of a functional criminal justice system with necessary checks and

302. Id. at 64; see also Chandra Lekha Sriram, Globalising Justice: From Universal Jurisdiction to Mixed Tribunals, 22 NETH. Q. HUM. RTS. 7, 25 (2004) ("Concerns have been raised among village leaders that when a perpetrator has been caught and locked up, this will do nothing to alleviate the economic and social suffering of the victim(s) and the village and hence an additional punishment is expected upon return."). During the Indonesian period, serious criminal matters were supposed to be handled by state courts, but these were not regarded as legitimate bodies to resolve disputes: "These courts remained inaccessible and alien, as they did not involve traditional leaders or the conflicting parties, they were not cost effective or time efficient, and the [sic] did not result in 'appropriate' sanctions or incorporate the important notion of compensation." UNDP REPORT ON THE COMMUNITY RECONCILIATION PROCESS, supra note 296, at 25 (emphasis added).

303. See supra text note 279 and accompanying text.

304. See, e.g., Prosecutor v. da Costa, Dili District Court, Special Panels for Serious Crimes, Case No. 7/2000, 16 (Oct. 11, 2001) (describing the defendant as "[A]n ignorant person who is illiterate."); Prosecutor v. Marques, Dili District Court, Special Panels for Serious Crimes, Case No. 09/2000, If 168 (Dec. 11, 2001) (defendant Gonsalo Dos Santos describing himself as illiterate); Prosecutor v. Bere, Dili District Court, Special Panels for Serious Crimes, Case No. 10/2000, 2 (May 15, 2001) (reporting on a defense motion that described the defendant as in illiterate civilian); Press Release, Judicial System Monitoring Programme, Court Sentences Liquica Militia Member to 20 Years Jail (Sept. 10, 2002) ("The judges emphasized that [the defendant] was illiterate ...."); Suzannah Linton \& Caitlin Reiger, The Evolving Jurisprudence and Practice of East Timor's Special Panels for Serious Crimes on Admissions of Guilt, Duress and Superior Orders, 4 Y.B. INT'L HUMANITARIAN L. 167, 182 (2001). 
balances," 305 and, according to one defense counsel, they have little conception even of rights. 306 Further, many Special Panels defendants speak only Tetum, a simple language that does not have words for some of the distinctions relevant to explaining certain crimes, ${ }^{307}$ while other defendants speak even less sophisticated tribal languages. ${ }^{308}$ Throughout its life, the Special Panels suffered from an inadequate staff of interpreters and translators. But even with a sufficient number of highly qualified interpreters, many Special Panels defendants would have been unable to grasp certain concepts necessary for understanding the crimes for which they were charged because their languages did not permit the explication of those concepts. Unlike ICTR defendants, then, who may be prepared to plead guilty to crimes against humanity but balk at assuming the label "génocidaire," most Special Panels defendants were unable even to comprehend the distinction. ${ }^{309}$ Indeed, as the following exchange from the Umbertus Ena case demonstrates, even a Panel's relatively straightforward efforts to ascertain whether a defendant understands the nature of the charges against him can fail.

JUDGE: Can you understand the nature of the accusation against you? Did you read
indictments or someone read it for you?

DEFENDANT: I'm saying like this, I will speak about, I said that I'm only a small man and there is people who would like to kill myself, and I defend myself so I could leave.

JUDGE: You will have time to make declaration, but now the tribunal would like to ask you whether you have read the indictments and that if you understand the nature of the indictments. Last time we read for you about the right that you have to access your legal defense and that you have opportunity to discuss about the accusation against you with your defense. Did you read the indictments submitted by the prosecutor against you?

305. UNDP REPORT ON THE COMMUNITY RECONCILIATION PROCESS, supra note 296, at 28; see also Telephone interview with Mohamed Othman, Former Prosecutor General of East Timor (Aug. 4, 2004).

306. Telephone interview with Alan Gutman, Defense Counsel, Special Panels for Serious Crimes (July 30, 2004).

307. For instance, in the Lolotoe case, defense counsel was not able to receive from a witness a comprehensible answer to the question "Do you know the difference between soldier and militia" because the word "difference" reportedly does not exist in Tetum. Judicial System Monitoring Programme, The Lolotoe Case, Trial Notes (Apr. 11, 2002) (on file with author).

308. See Press Release, Judicial System Monitoring Programme, Court Sentences Liquica Militia Member to 20 Years Jail (Sept. 10, 2002) ("The judges emphasized that [the defendant] was illiterate and did not speak Indonesian or Tetum, East Timor's national language, only speaking his local dialect."); Judicial System Monitoring Programme, Speclal Panels for SERIOUS CASES - WEEKLY REPORT (Jan. 27-31, 2003) (In the José Cardoso case, "['T] he court was delayed until 1012 hours because of difficulties in finding a Bunak language interpreter, the only local dialect spoken by the witness.").

309. Telephone interview with Alan Gutman, Defense Counsel, Special Panels for Serious Crimes (July 30, 2004). 
DEFENDANT: Can I speak?

JUDGE: Yes please.

DEFENDANT: Would you wasn't me to speak loudly or to answer your question?

DEFENSE COUNSEL: Your honor, my client does not understand. If you can give me time 5 minutes to speak to him about what is happening now. I have spoken to him last time, but it seems that he still not understand.

JUDGE: The court gives five minutes for the defense to talk to his client about this, but first let's try again.

JUDGE: Umbertus Ena, do you know why you are here?

DEFENDANT: Because of what happened in 1999.

DEFENSE COUNSEL: I'm worrying that he may mitigated himself and I worry because be is very unsophisticated man.

JUDGE: This court gives five minutes to both defense counsels to talk to their clients. This court is postponed to 5 minutes.

\section{AFTER 5 MINUTES BREAK}

JUDGE: After the consult witb tbe defense counsel, I think that I can ask the question, Umbertus Ena, can you please stand up? Do you understand the accusation against you?

DEFENDANT: I know.

JUDGE: Do you know the nature of the accusation?

DEFENDANT: I know. 310

Guilty-plea colloquies proved even more worrisome as they suggested that many Special Panels defendants pled guilty without any real awareness of what they were doing or of the consequences of their pleas. When Special Panels judges asked Benjamin Sarmento if he wanted to plead guilty, for instance, he seemed to indicate that he did, but he repeatedly asserted that he had been ordered to commit the crimes, making such statements as: "People send us to kill. That's why we did it. That is like we accept our guilty," and "This charge, I accept, because they told me to do it. That's why I accept. But the problem is that for me to think about doing it, I wouldn't have done it. That is because I was told to do it." 311 Despite the obvious ambiguities

310. Prosecutor v. Ena, Dili District Court, Special Panels for Serious Crimes, Case No. 05/2002, Transcript at 2 (Feb. 14, 2003).

311. Public Prosecutor v. Sarmento, Dili District Court, Special Panel for Serious Crimes, Court Record at 10 (June 30, 2003) (on file with author). 
in Sarmento's admissions, the Panel accepted his guilty plea, making no attempt to apprise him of the consequences of his action. A few minutes later, Sarmento's co-defendant, Romeiro Tilman, also attempted to plead guilty, and his responses were even more equivocal. Tilman apparently held the victim down while someone else killed him. When asked if he was prepared to plead guilty, Tilman responded:

I agree. This is not because of what I wanted, but because those in charge forced me. I did it. It is not that I used a knife, or a machete to kill. I didn't. The commander of militia forced me. I was scared of death. My colleague did it. And I have been in jail for over 3 years. This wrong is not mine. The person who did this is not here. And I, have come to accept my wrong. . . . I feel that I am wrong because I held with my hands. ${ }^{312}$

Because Tilman claimed to have been forced to commit the crime, the court adjourned to allow him to consult with his lawyer. Returning from his consultation, Tilman said simply: "I am guilty." 313

The Special Panels defendants' already-limited ability to make informed decisions about the guilty-plea process was further impeded by an insufficient staff of translators, a problem mentioned above and one that was especially acute at the Special Panels' outset. Trials had to be postponed for lack of interpreters, ${ }^{314}$ and in many cases, defense counsel were not provided their own interpreters, so they had to seek help from prosecution interpreters or court interpreters in order to consult with their clients. ${ }^{315}$ Even in the Special Panels' later days,

312. Id. at 15 .

313. Id. at 16 .

314. See Suzanne Katzenstein, Note, Hybrid Tribunals: Searching for Justice in East Timor, 16 HaRv. Hum. RTS. J. 245, 252 (2003); Judicial System Monitoring Programme, SPECial PANELS FOR SERIOUS CASES - WEEKLY REPORT (Jan. 27-31, 2003) (reporting that the trial was postponed because of the difficulty of finding a language interpreter and that a prosecution witness was never called to testify because translation was unavailable). Further, some judgments have been issued in only one of the Panels' official languages, even though judges on that very Panel were unable to read the judgment. See de Carvalho v. Prosecutor General, Court of Appeal of East Timor, Criminal Appeal No. 25 of 2001, Judgment of Fredrick Egonda-Ntende, If 1 (Oct. 29, 2001) (Because the Court of Appeal judgment "is in Portuguese, a language I do not understand, and there are no translation services, ... I have therefore decided to briefly explain my reasons for the decision made today."); Fernandes v. Prosecutor General, Court of Appeal of East Timor, Criminal Appeal No. 7 of 2001, Judgment of Fredrick Egonda-Ntende, If 36, (June 29,2001 ) ("The majority of this court, if I understand there [sic] position correctly, (that position is set out in Portuguese, a language $I$ do not understand and for which no translation is provided ....)"; JUSTICE FOR TIMOR-LESTE, supra note $279, \S 3.10$ ("[D]ecisions, two thirds of which are delivered in Portuguese, are not translated into English, Bahasa Indonesia or Tetum with the result that some trial judges, defense lawyers and suspects cannot understand them."); see also de Bertodano, supra note 271, at 233 (reporting that a judgment "was given in Portuguese and, despite an obligation on the Court to provide translations, it has not heen made available in English").

315. Judicial System Monitoring Programme, Lolotoe Trial Observation Weekly Summary for 21-25 October (2002) (unpublished document, on file with author). 
interpreters were required to work for extensive periods of time without breaks, ${ }^{316}$ and they consequently often failed to translate crucial exchanges between counsel and judges into languages that the defendants could understand. ${ }^{317}$ Thus, even if a Special Panels defendant was one of the rare sort who understood the nature of the guilty-plea process and wished to condition his plea on the promise of a sentence reduction, the defendant may well have had no ability to communicate such a desire.

In sum, Special Panels defendants are culturally disposed to confess their crimes without concern for any sentencing benefits they might receive. In the East Timorese world view, offenders must reconcile with their victims if balance is to be restored following a crime, and the offender's admission of wrongdoing constitutes a vital first step in that process of reconciliation. For that reason, during the Panels' first few years, virtually every defendant immediately admitted his wrongdoing upon apprehension. That these defendants might receive a sentence discount in exchange for their admissions was of little or no consequence to them. They confessed instead for the reasons just canvassed, and their lack of education, their limited language skills, and the dearth of interpreters at the Special Panels prevented these defendants from evaluating the benefits that their confessions might have gained for them if they had been inclined to seek them.

It is typically the role of defense counsel to seek such benefits for their clients, but while early Special Panels defendants were formally represented by defense counsel, that representation was insufficient by any measure. Many early defense counsel were East Timorese who had little or no training in criminal defense, let alone in plea bargaining. In addition, the Special Panels conducted their work on a meager $\$ 6.3$ million annual budget, and, at the outset, virtually none of those funds were allocated to defense costs. ${ }^{318}$ As a result, in the early cases defense attorneys had no ability to undertake

316. One interpreter, who was translating into Bahasa Indonesia, Tetum, and Portuguese asked to have the afternoon off, maintaining that he was exhausted. Because the Panel had no other interpreters, he was not allowed to leave. Judicial System Monitoring Programme, The Lolotoe Case, Trial Notes (Oct. 31, 2002) (unpublished document, on file with author). Another translator repeatedly complained about working conditions, $i d$., and was later disqualified after he made a number of loud outbursts during court sessions. Judicial System Monitoring Programme, The Lolotoe Case, Trial Notes (Nov. 13, 2002) (unpublished document, on file with author).

317. The Lolotoe CASE: A SMall Step ForwaRd, supra note $278, \S 3.4$.

318. $\$ 6$ million of the $\$ 6.3$ million was allocated to the prosecution. Virtually all of the remaining $\$ 300,000$ constituted the salaries of the international judges. Cohen, supra note 279, at 5. As Cohen relates, "No one in either the Public Defenders' office or UNTAET could tell me whether or not the Public Defenders had a budget or, if so, what it was." Id. 
investigations, and indeed, not a single defense witness was called to testify in the first fourteen trials, not even in a massive case charging ten defendants with crimes against humanity. ${ }^{319}$ The Special Panels prosecutors with whom I spoke indicated that early defendants had so little assistance that the prosecutors themselves sometimes felt compelled to step into the role of defense counsel to caution defendants about making incriminating statements. ${ }^{320}$

Sentencing discounts thus had no influence over the guilty-plea decisions of early Special Panels defendants. As noted above, virtually all of the early Special Panels defendants immediately admitted their wrongdoing upon apprehension despite the fact that no benefits were offered them, and some tried formally to plead guilty. In a number of cases, the Special Panels declined to accept these guilty pleas because the defendants' admissions did not precisely match the charges contained in the indictment, or because the defendants maintained that they had been forced-or at least ordered-to commit the acts, so questions remained about their mens rea. ${ }^{321}$ Although these

319. Id.; de Bertodano, supra note 271, at 232; see JUDICIAL SYSTEM MONITORING Programme, General Prosecutor v. Marques (The los Palos Case): A JSMP Trial Report $\S$ 2.3.2.2 (Mar. 2002) ("No witnesses or physical evidence were presented by tbe defence."); id. § 3.2.2.1 ("The defence raised other reasons for not calling witnesses for the trial, of which one was lack of resources. They frequently stated that they lacked both cars and the time to travel to the districts to speak to potential witnesses, to provide transport to court and to pay for the witness expenses such as food and lodging while being in Dili."). See also Prosecutor v. Gonçalves Bere, Dili District Court, Special Panel for Serious Crimes, Case No. 10/2000, Judgment at 4 (May 15, 2001) ("The Defence did not present any witnesses or evidence."); Prosecutor v. Dos Santos Laku, Dili District Court, Special Panels for Serious Crimes, Case No. 8/2001, Judgment, If 3 (July 25, 2001) (same); Prosecutor v. Soares Carmona, Dili District Court, Special Panel for Serious Crimes, Case No. 03 C.G. 2000, Judgment at 2 (Apr. 19, 2001); Prosecutor v. Leki, Dili District Court, Special Panel for Serious Crimes, Case No. 05/2001, Judgment, ๆ 14 (Sept. 14, 2002) ("The Legal Counsel of the accused did not bring any witnesses nor [sic] he presented any evidence.").

320. Telephone interview with Brenda Sue Thornton, former prosecutor Special Panels for Serious Crimes (Sept. 12, 2005). Cohen also reports that the "prosecution has not sought to take advantage of [defense] inadequacies, but has repeatedly tried to help novice defense counsel by coaching them about how to make motions or objections." Cohen, supra note 279 , at 5.

321. See, e.g., Prosecutor v. Valente, Dili District Court, Special Panels for Serious Crimes, Case No. 03/2001, 2 (June 19, 2001) [hereinafter Valente] (observing that although the defendant tried to enter a guilty plea, the "Special Panel deemed that there was no confession of guilt in this case because 'the statement of the accused does not correspond with the facts alleged in the indictment and that there is no clear consultation with the legal representative."); JUDICIAL System Monitoring Programme, "Los Palos" Case Trial Notes 4-6 (Sept. 9, 2001) (on file with author). Linton \& Reiger, supra note 304, at 188 ("The post-Fernandes practice suggests that that [sic] the Special Panels now shy away from taking decisions at the pre-trial stage and prefer to proceed to trial whenever the issue of coercion is raised."). In the Gaspar Leki case, for instance, tbe defendant pled guilty to murder because he shot and killed a man who had been hiding in the bushes. The Panel initially accepted the guilty plea, and only as a result of further questioning did it learn that, although the defendant had been ordered to shoot anything that moved, he believed that he was shooting a wild pig in the bush. Since tbe element of deliberate 
defendants did not receive any sentencing concessions from the prosecution, the Panels themselves ostensibly considered the defendants' guilty pleas to be mitigating factors in sentencing. A cursory examination of the sentences imposed on the first handful of defendants to be tried individually, as well as the sentences imposed on the ten defendants who were tried together in the Special Panels' first multi-defendant case indicates, however, that early defendants received little, if anything, for their guilty pleas.

João Fernandes was the first Special Panels defendant to plead guilty, and his sentencing Panel asserted that it gave him credit for his guilty plea by treating it as a mitigating factor in sentencing. ${ }^{322}$ The Panel also considered the superior orders pursuant to which Fernandes committed the crime a mitigating factor, and it sentenced him to twelve years' imprisonment for the one murder he committed. ${ }^{323}$ Following the Fernandes decision, the Panel conducted trials in a number of cases featuring similar facts. In particular, Carlos Soares, Manuel Bere, Agustinho da Costa, and Augusto Tavares were each convicted of one murder following a trial, and each had the benefit of superior orders as a mitigating factor. These cases, thus, resembled Fernandes in every respect except for Fernandes's guilty plea. Soares, Bere, da Costa, and Tavares received sentences of imprisonment of fifteen-and-one-half years, fourteen years, fifteen years, and sixteen years, respectively. Because these sentences are on average approximately 20 percent longer than Fernandes's sentence, it might appear that Fernandes received a 20 percent discount as a consequence of his guilty plea. However, another defendant, José Valente, was convicted of one murder following a trial, and without the benefit of either superior orders or a guilty plea, received a sentence of twelve-and-one-half years' imprisonment, ${ }^{324}$ only six

intent to commit murder was called into question, the Panel reversed its decision to accept the guilty plea and proceeded to trial. Id. at 17-18.

322. Prosecutor v. Fernandes, Dili District Court, Special Panel for Serious Crimes, Case No. 01/00 C. G. 2000, Judgment, If 20(b) (Jan. 25, 2001).

323. Id. If 20 and Verdict. Fernandes was charged only with murder because financial constraints forced prosecutors to charge early Special Panels defendants with domestic crimes under the less demanding Indonesian criminal code, rather than with international crimes. See Linton, supra note 276, at 215; Suzannah Linton, Correspondents' Reports, in Y.B. INT'L HUMANITARIAN L. 471, 481 (2000) (noting that the decision to charge domestic crimes was a "pragmatic" one given the "inadequate resources and the immensity of the task of proving international crimes" and further noting that because suspects could not be detained indefinitely pending investigation of international crimes, "[t]he only other acceptable option would have been to release the suspects.").

324. Valente, supra note 321, at 11-12. Valente did admit "some facts before the Court and freely cooperated with the Public Prosecutor about his involvement in becoming a member of 
months longer than the sentence imposed on Fernandes. Further, Joseph Leki was convicted of committing four murders-three more than Fernandes-and with superior orders as a mitigating factor, Leki received a sentence of thirteen years' imprisonment, ${ }^{325}$ just one year longer than Fernandes's sentence. Thus, after comparing these sentences, it is not clear whether Fernandes received any discount for his guilty plea.

The Special Panels conducted its first multi-defendant trial in the Los Palos case, and the sentences imposed on the ten Los Palos defendants similarly fail to reveal the quantum of discount, if any, that the Special Panels bestowed on defendants pleading guilty. Nine of the Los Palos defendants were members of the Team Alfa militia, while the tenth, Joni Marques, was one of Team Alfa's commanders. The Los Palos indictment charged Joni Marques with seven counts, and in his opening statement, Marques attempted to plead guilty to three of the counts, ${ }^{326}$ though he had not negotiated with the prosecution for any sentencing concessions in exchange for his guilty pleas. $^{327}$ The Panel declined to accept two of the attempted guilty pleas, because Marques's admissions did not precisely match the charges, ${ }^{328}$ but it did accept the third, which related to the murders of nine clergy members and journalists. ${ }^{329}$ In its sentencing, the Panel stated that it considered as a mitigating factor Marques's guilty plea, ${ }^{330}$ but the Panel's judgment gives little indication of what benefit, if any, Marques received for that guilty plea.

The Panel determined that Marques was "in charge" of the operation to kill the clergy and journalists. While the Panel

Team Ratih/Panah." Id. at 11. But the same could be said of most of the defendants discussed thus far.

325. Prosecutor v. Leki, Dili District Court, Special Panels for Serious Crimes, Case No. 05/2000, Judgment, 11-12 (June 11, 2001).

326. Judicial System Monitoring Programme, "Los Palos" Case Trial Notes 4 (Sept. 9 , 2001) (on file with author). Marques also admitted to participating in the crimes described in the remaining counts, but, with respect to those crimes, he challenged various aspects of the prosecution's case. Id.; Prosecutor v. Marques, Dili District Court, Special Panels for Serious Crimes, Case No. 09/2000, ๆा 43-63 (Dec. 11, 2001) [hereinafter Marques].

327. Telephone interview with Stuart Alford, former prosecutor, Special Panels for Serious Crimes (Feb. 17, 2005).

328. Judicial System Monitoring Programme, "Los Palos" Case Trial Notes 6 (Sept. 9, 2001) (on file with author).

329. Marques, supra note 326, I 70. Marques's admissions even with respect to that count did not precisely match the prosecution's allegations because Marques denied that he was the commander of Team Alfa. Id. I 67. The Panel apparently considered the charges and the admissions a close-enough fit, however, and it made its own finding that, despite his protestations to the contrary, Marques was in fact a commander. Id. If 921.

330. Id. I 1069. The Panels also considered as a mitigating factor the inculpatory statements that Marques made that did not rise to the level of a guilty plea. Id. ๆ 1055. 
acknowledged that the plan itself was drafted by Indonesian officers, it considered the fact that Marques supervised the plan's implementation to be an aggravating factor. ${ }^{331}$ The Panel sentenced Marques to nineteen years' imprisonment for this count, ${ }^{332}$ which is the same sentence that the Panel imposed on two of Marques's codefendants, neither of whom had a leadership role in the operation. ${ }^{333}$ The mitigating effect of Marques's guilty plea, then, seems to have been to negate the aggravating effect of his supervisory role in the killing operation; however, it is not clear what the aggravating effect would have been since a comparison of the sentences that the Panel imposed on Marques and his co-defendants on the other counts is not very illuminating. Marques, for instance, was convicted on another count of ordering a murder, while co-defendant João da Costa was convicted of physically assisting in that murder. The Panel considered as an aggravating factor Marques's supervisory role, and he received a nineteen year sentence, while da Costa, who was not considered a supervisor, received a seventeen year sentence. ${ }^{334}$ The comparison is not particularly useful, however, because the two defendants were involved in the murder in very different ways and because the Panel also considered da Costa "one of the leaders in arresting the victim," so da Costa's sentence, like Marques's, may also have been enhanced to some degree as a result of his leadership role in the arrest.

A possibly more useful comparison can be made from the sentences that the Los Palos Panel imposed on a count involving the expulsion of civilians and the destruction of villages. The Panel determined that although there was insufficient evidence to prove that Marques had burned any houses himself, Marques was present when expulsions and house-burnings took place, and his presence was that of a commander. ${ }^{335}$ The Panel considered his supervisory position as an aggravating factor and sentenced him to seven years' imprisonment. The Panel went on to find that co-defendant Paolo da Costa himself burned houses and expelled villagers, but it found that he did so pursuant to the superior orders of Joni Marques. In sentencing Paolo da Costa, then, the Panel not only did not find any aggravating factors with respect to a leadership role, but considered as a mitigating factor the superior orders under which Paolo da Costa

331. Id. ๆ 1068.

332. Id. ๆ 1071.

333. Id. शी 1077, 1084. The Panel imposed 18 year sentences on three other co-defendants. Id. ๆๆ 1091, 1098, 1113. It imposed a 17 year sentence on a final co-defendant. Id. ๆ 1106.

334. Id. ๆๆ 1012-23.

335. Id. ๆ 796. 
committed the crime. ${ }^{336}$ Yet, the Panel sentenced da Costa to six years' imprisonment, ${ }^{337}$ a term only one year shorter than the term it imposed on Marques. Again, the facts underlying the two convictions are by no means identical, but the sentences do suggest that Marques's supervisory role did not earn him a significant sentence increase. To the extent, then, that Marques's guilty plea for the killing of the clergy and journalists merely negated the sentence increase that the Panel imposed for his supervisory role, one can surmise that Marques's guilty plea benefited him little.

\section{B. Enhancing the Influence of Sentencing Discounts: The Role of Defense Counsel}

Although most Special Panels defendants would have pled guilty without the lure of sentencing concessions, those concessions ended up playing an influential role in determining how many defendants, and which ones, pled guilty during the last few years of the Special Panels' existence. Later Special Panels defendants themselves remained as uninfluenced by sentencing discounts as their earlier counterparts, but because funding increased for defense counsel as time went on, later defense counsel were more numerous and better able to make efforts to advance their clients' interests. In later Special Panels' cases, then, defense counsel routinely insisted that their clients receive sentence discounts if they were to plead guilty. As a result of this insistence, plea negotiations became commonplace during the later years of the Special Panels, and prosecutors were forced to offer defendants sentencing concessions if they wanted to procure guilty pleas.

Not every defense counsel engaged in bargaining. Indeed, some routinely advised their clients not to plead guilty despite the potential for a sentence reduction. Some defense counsel hailing from civil-law countries, for instance, were relatively unfamiliar with plea bargaining and were opposed in principle to the practice. Other defense counsel, like many ICTR defense counsel, declined to bargain with the prosecution because they believed their clients to be innocent and could not in good faith encourage them to plead guilty to crimes they did not commit. Defense counsel frequently described Special Panels' investigations as one-sided and based on insufficient 
evidence. ${ }^{338}$ One defense counsel went so far as to opine that 85 to 90 percent of the Special Panels' convictions would be acquittals in any other jurisdiction. ${ }^{339}$ That belief notwithstanding, the fact remained that the Special Panels convicted eighty-four out of eighty-seven defendants. ${ }^{340}$ Although those dismal statistics motivated some defense counsel to strongly encourage their clients to plead guilty so long as the prosecution offered reasonable concessions, others felt uncomfortable participating in a process that, in their minds, perpetuated an injustice. The fact that most Special Panels defendants had no ability to understand the nature of the crimesagainst-humanity charges to which they would have been pleading guilty raised additional concerns for some defense counsel. ${ }^{341}$

When bargaining did take place, it centered on the sentence that the prosecution would ask the Panel to impose. Although prosecutors initially had little need to offer incentives to expedite proceedings, by the spring of 2003, the UN had made plans to end its mission in East Timor in May 2004. The lifespan of the mission was extended for an additional year, ${ }^{342}$ but by August 2003, the prosecutorial arm of the Special Panels had already begun downsizing. ${ }^{343}$ The realization that the Special Panels would close its doors in a short time without having completed its work ${ }^{344}$ motivated prosecutors to make substantial efforts to obtain guilty pleas. Prosecutors began promising to recommend specific sentences to the Special Panels in exchange for defendants' guilty pleas, and the

338. See Telephone interview with Alan Gutman, Defense Counsel, Special Panels for Serious Crimes (July 30, 2004); Email interview with Sehastian Appenah, Defense Researcher/Lawyer, Special Panels Defence Lawyers Unit (Dec. 6, 2004).

339. Telephone interview with Alan Gutman, Defense Counsel, Special Panels for Serious Crimes (July 30, 2004).

340. Information Release, Serious Crimes Unit, Special Panels Acquits Aparacio Guterres (Feb. 16, 2005). The Special Panels acquitted four defendants, but one acquittal was reversed on appeal. See Information Release, Serious Crimes Unit, Special Panels Trial Ends with an East Timorese TNl Soldier Being Acquitted of Crimes Against Humanity (Dec. 8, 2003) (reporting on the acquittal of Paulino de Jesus); Judicial System Monitoring Programme, Court of Appeal Overturns Decision of Acquittal of the SPSC, in JUSTICE UPDATE 11/2004 (Nov. 4-9, 2004) (reporting on the appellate reversal of the acquittal).

341. Telephone interview with Sylvia de Bertodano, former Defense Counsel, Special Panels for Serious Crimes (Dec. 2, 2004).

342. S.C. Res. 1573, U.N. Doc. S/RES/1573 (Nov. 16, 2004).

343. Judicial System Monitoring Programme, The Future of the SERIous CRIMEs Unit: JSMP ISSUE REPORT 5-8 (Jan. 2004); see also Amnesty International, Indonesia and Timor Leste: International Responsibility for Justice, AI INDEX: ASA 03/01/2003 (Apr. 14, 2003).

344. Sec JUSTICE FOR TIMOR-LeSTE, supra note 279 , 1 (asserting that the Special Panel's "chances of completing its task ... are extremely remote."); Sylvia de Bertodano, Have Some Faith in Iraqi Justice, THE TIMEs (London), Jan. 20, 2004, at 7 ("It is highly unlikely that all trials, let alone all appeals, will be completed before the funds run out."). 
Special Panels apparently never imposed a sentence longer than that recommended by the prosecution. ${ }^{345}$ Indeed, as I will briefly describe below, one Special Panel tried to construct a sentencing framework that would encourage defendants to plead guilty, but its efforts may have been for naught.

In the Agustinho Atolan case, a Special Panel set forth a specific and generous sentencing discount to bestow on defendants who pled guilty. Agustinho Atolan pled guilty to one count of murder as a crime against humanity, and the defense and prosecution agreed to recommend a seven year prison sentence. After surveying analogous past cases, the Panel concluded that the Special Panels' practice had been to sentence defendants convicted of one murder following a trial to a term of imprisonment of between twelve and sixteen years. 346 The Panel went on to praise defendants who, "being regretful, [choose] a procedural option which spares time and resources of the Court," and it asserted that if such defendants were to receive an appropriate "advantage" in exchange for their guilty plea, then their sentences should be halved. To support the need for a substantial discount, the Panel observed: "A less drastic approach proved to be useless: after the first decision of the Special Panel, in the João Fernandes case, where the Court took a less lenient decision, more than one year elapsed before a second guilty plea was submitted." 347 Consequently, after concluding that it would have sentenced Atolan to a term of fourteen years' imprisonment had the case proceeded to trial, the Panel sentenced him to a term of seven years' imprisonment, ${ }^{348}$ the exact sentence recommended by the prosecution.

Six months later another Panel adhered to the framework articulated in Atolan in the Martins \& Gonçalves case. There, Anastacio Martins pled guilty and was convicted of murder as a crime against humanity for the killing of three people, while his codefendant, Domingos Gonçalves, proceeded to trial and was also convicted of murder as a crime against humanity for the killing of three people and of deportation as a crime against humanity. Cutting and pasting several paragraphs from the Atolan judgment, the Panel

345. Telephone interview with Essa Faal, former Chief of Prosecutions, Special Panels for Serious Crimes, (Nov. 16, 2004).

346. Prosecutor v. Atolan, Dili District Court, Special Panels for Serious Crimes, Case No. 3/2003, Judgment, 6 (June 9, 2003). Without further explanation, the Panel asserted that the sentences imposed on three defendants that had fallen outside this range were justified by "specific reasons." Id. at 7.

347. Id.

348. Id. at 8. 
held that a guilty plea should normally result in a 50 percent reduction in sentence. 349 The Panel then determined that had Martins proceeded to trial, a single brutal murder of the sort he committed would have warranted a sentence of sixteen years' imprisonment, and that his three murders would have resulted in a twenty-three year sentence. Discounting the sentence by half, then, on the basis of his guilty plea, the Panel sentenced Martins to eleven-and-one-half years' imprisonment, which was within the eight-to-twelve year range recommended by the prosecution. ${ }^{350}$ Gonçalves did not plead guilty, so he was in line to receive a twenty-three year sentence for the three murders he committed and an additional year of imprisonment for the deportation count. Although Gonçalves did not receive any discount for a guilty plea, the Panel did consider, in mitigation, his low rank and the substantial current difficulties that he and his family faced. ${ }^{351}$ In light of these mitigating factors, the Panel sentenced Gonçalves to fifteen years' imprisonment. ${ }^{352}$

Despite the potential benefits of a clear rule, the sentencing framework articulated in Atolan and Martins \& Gonçalves has not been followed. Indeed, a Special Panel composed of two of the same three judges who decided Atolan subsequently imposed a number of lenient sentences following trials that undercut efforts to procure guilty pleas. One month after the Martins \& Gonçalves decision, for instance, this Panel convicted Damiao da Costa Nunes of two counts of murder as crimes against humanity, and one count of persecution as a crime against humanity. Pursuant to the framework set forth in Atolan and Martins \& Gonçalves, da Costa Nunes should have received a sentence of more than fourteen years' and less than twentythree years' imprisonment. Instead, the Panel made no mention of the Atolan and Martins \& Gonçalves sentencing framework, and despite concluding that there existed no mitigating factors, ${ }^{353}$ it sentenced him

349. Prosecutor v. Martins, Dili District Court, Special Panels for Serious Crimes, Case No. 11/2001, Judgment, 17 (Nov. 13, 2003).

350. Id. at 18.

351. Id. The Panel noted for instance, that Gonçalves is unemployed, that he "has lost a leg, cut by his own wife, his wife is mad; his children are young and his mother is very old." Id.

352. Id. at 19.

353. Prosecutor v, da Costa Nunes, Dili District Court, Special Panels for Serious Crimes, Case No. 1/2003, Judgment, ๆ $65-76$ (Dec. 10, 2003). 
to a mere ten-and-one-half years' imprisonment. ${ }^{354}$ That Panel's sentencing in subsequent cases was similar. ${ }^{355}$

The fact that the guilty-plea rate at the Special Panels was as high as 50 percent, despite the Special Panels' somewhat arbitrary sentencing practices, acts as additional confirmation that sentencing discounts did not motivate the guilty-plea decisions of Special Panels defendants. That is, the uncertainty inherent in the Special Panels' sentencing would have deterred a substantial proportion of defendants from pleading guilty if the defendants' primary goal had been to receive a sentence reduction. ICTY defendants stopped pleading guilty, for instance, as soon as Trial Chambers started imposing sentences longer than those recommended by the prosecution. Since other factors were more influential to the guilty-plea decisions of Special Panels defendants, the Panels' arbitrary sentencing practices had a much more limited deterrent effect. ${ }^{356}$

In sum, sentence concessions appeared on the surface to play much the same role at the Special Panels that they do at the ICTY or in national criminal justice systems since Special Panels defendants who were offered reasonable discounts in exchange for their guilty pleas were much more likely to enter guilty pleas than defendants who were not. Below the surface, however, the picture is very different; at the ICTY and in national criminal justice systems, it is the defendant's ardent desire to reduce his incarceration time that inspires his counsel to insist on concessions from the prosecutor.

354. Id. at 20. Judge Blunk, the judge who had not participated in Atolan dissented to the sentence, asserting that it failed to meet the goals of deterrence, retribution, reconciliation, and reprobation. Id. at 22 (Blunk, J., dissenting).

355. For instance, a Panel composed of the same members convicted Umbertus Ena after a trial of murder and inhumane acts as crimes against humanity for the killing of two independence supporters and an assault on a third. OFFICE OF THE DEPUTY GENERAL Prosecutor for Serious Crimes Timor leste, Serious Crimes UnIT Update 9 (Apr. 30, 2004). Again, pursuant to the sentencing framework articulated in Atolan and Martins \& Gonçalves, Ena should have received a sentence of more than fourteen years' imprisonment and less than twenty-three years' imprisonment, but the Panel sentenced him to an eleven-year term. The Panel also convicted Marcelino Soares after a trial of one count of murder as a crime against humanity, one count of torture as a crime against humanity, and one count of persecution as a crime against humanity for killing one independence supporter and severely beating two others. After determining that not only did the defendant fail to express regret but that he "appeared pleased with himself, when the victims of his torture testified to his savage cruelty, and showed the severe wounds inflicted by him," the Panel sentenced him to eleven years' imprisonment. Prosecutor v. Soares, Dili District Court, Special Panels for Serious Crimes, Case No. 11/2003, Judgment, Disposition, 12-14 (Dec. 11, 2003).

356. However, the Panels' arbitrary sentencing did act to deter some defense counsel wbo were already slightly uneasy about plea bargaining from advising their clients to plead guilty. One counsel who expressed discomfort with plea bargaining, for instance, opined that, given the Special Panels' seemingly random sentencing practices, one could never be certain that a defendant would actually gain anything from pleading guilty. 
Although Special Panels defendants may likewise desire to reduce their terms of imprisonment, that desire is not the key factor prompting them to plead guilty. Instead, a variety of cultural and socio-economic factors coalesce to motivate Special Panels defendants to confess even if they do not receive any sentencing benefit for doing so. The influence of sentence discounts at the Special Panels, then, held sway not primarily over Special Panels defendants but rather over their counsel.

\section{CONCLUSION}

Plea bargaining can be practiced in any number of ways, and different forms of plea bargaining are more prevalent in some jurisdictions than in others. Charge bargaining is most prevalent in American jurisdictions where prosecutors exercise broad discretion over charging decisions that largely define the limits of criminal punishment. Sentence bargaining will be practiced alternatively or additionally in American jurisdictions where judges virtually always sentence in accordance with prosecutorial recommendations. Bargaining between prosecution and defense tends to be less overt in England and Australia. Although charge bargaining does occur, ${ }^{357}$ implicit bargaining - the least obvious form of plea bargaining-is probably most prevalent in those countries. ${ }^{358}$ Both charge bargaining and sentence bargaining, wherever practiced, can concern not only the defendant's guilty plea but other issues as well. In exchange for charging or sentencing concessions, the prosecution might require the defendant to provide information about the crimes of other

357. See generally SANDERS \& YOUNG, supra note 2, at 441-68 (describing charge bargaining in England); Richard Read, Plea Negotiation and the Role of the Prosecution in Victoria, $6 \mathrm{~J}$. JUD. ADMIN. 25 (1996) (discussing charge bargaining in some jurisdictions of Australia).

358. On implicit bargaining in Australia, see Willis, supra note 2. On implicit bargaining in the United Kingdom, see SANDERS \& YouNG, supra note 2, at 398; R. v. March [2002] EWCA (Crim) 551, 2002 Crim.App. R(S) 98 (Eng.); Du Plooy v. H.M. Advocate, High Court of Justiciary, [2003] S.L.T. 1237, 2003 WL 22257793 (Scot.). As Penny Darbyshire writes:

Plea bargaining in England and Wales cannot be directly likened to negotiating in the United States, because we lack certain elements common in US legal systems: our prosecutors do not make sentence recommendations; most of our offences do not carry minimum sentences; our judges are not supposed to indicate the sentences they are minded to impose. In England, then, we tend to speak of plea bargaining as the exchange of a guilty plea for a reduced charge or some hope of a reduced sentence. The last can be induced without involvement of the prosecutor, or any explicit bargain. This is called 'implicit bargaining.'

Darbyshire, supra note 2 , at 897. 
defendants, for instance, or to waive his right to appeal ${ }^{359}$ or his right to receive exculpatory evidence collected by the prosecution. ${ }^{360}$

Although plea bargaining can take many forms and result in many different sorts of agreements, the force driving all of them is the defendant's desire for a sentence reduction. Although a small percentage of defendants charged with domestic crimes will plead guilty without concern for sentencing concessions because the evidence against them is so compelling, ${ }^{361}$ domestic defendants in the main agree to self-convict because they expect to receive shorter sentences. Indeed, the fact that sentence discounts motivate domestic defendants to plead guilty virtually goes without saying in the pleabargaining literature. It is simply understood that defendants prosecuted in Western criminal justice systems seek to minimize their incarceration time. While reducing the length of their sentence may not be their sole concern, it is so significant a concern that an offer of a sentence reduction will be a persuasive inducement in virtually every case. That inducement will prove all the more compelling to defendants who are in fact guilty of the crimes for which they have been charged and who are confronted with substantial evidence of that guilt. But reports indicate that even some innocent defendants likewise plead guilty to avoid the risk of a longer sentence imposed upon conviction after a trial. ${ }^{362}$

359. Most plea agreements at the ICTY and the Special Panels, for instance, require defendants to waive their right to appeal their sentence if they are sentenced within the range agreed upon in the plea agreement. See, e.g., Momir Nikohic Plea Agreement, supra note 73, II 14; Obrenović Plea Agreement, supra note 73, I 14; Telephone interview with Essa Faal, Chief of Prosecutions, Special Panels for Serious Crimes (July 30, 2004).

360. See, e.g., Erica G. Franklin, Note, Waiving Prosecutorial Disclosure in the Guilty Plea Process: A Debate on the Merits of "Discovery" Waivers, 51 STAN. L. REv. 567 (1999) (discussing the practice of waiving discovery rights in plea bargain contracts); Shane M. Cahill, Note, United States v. Ruiz: Are Plea Agreements Conditioned on Brady Waivers Unconstitutional?, 32 GOLDEN GATE U. L. REV. 1 (2002) (examining the constitutionality of plea agreements conditioned on the defendant's willingness to waive his right to receive impeachment evidence). Proposed amendments to the United States Federal Rules of Criminal Procedure would put an end to bargaining over the defendant's right to receive exculpatory evidence because they would require federal prosecutors to disclose all exculpatory evidence fourteen days before a guilty plea is entered. Robert W. Tarun et al., Proposed Codification of Disclosure of Favorable Information Under Federal Rules of Criminal Procedure 11 and 16, 41 AM. CRIM. L. REV. 93, 95 (2004).

361. Albert W. Alschuler, The Changing Plea Bargaining Debate, 69 CAL. L. REV. 652, 657 (1981) (observing that some defendants plead guilty because they "sense no chance of victory at trial"); Weninger, supra note 3 , at 293.

362. Michael Zander \& Paul Henderson, The Royal Commission on CRiminal Justice, Crown Court STudy 139 (1993); John Baldwin \& Michael McConville, Plea Bargaining and Plea Negotiation in England, 13 LAW \& Soc'Y REV. 287, 298 (1979) (reporting that "innocent persons are frequently placed at risk and that, on occasion, the weaker and less knowledgeable are wrongly persuaded to plead guilty."). 
The relatively straightforward relationship between sentencing discounts and guilty pleas just described does not exist in the context of international crimes. Although some international defendants rely on sentence-based calculations when deciding whether or not to plead guilty, for a substantial proportion of international defendants currently in the dock, sentence inducements have only limited persuasive value. The reasons for their lack of influence vary with the circumstances. High-level ICTR defendants, for instance, are so convinced of their innocence, so ideologically committed to their characterization of the Rwandan conflict, and so concerned about their place in the history books that virtually no sentence inducement will persuade them to plead guilty to genocide. Low-level Special Panels defendants, by contrast, are so ignorant about their legal rights and so culturally disposed to admitting wrongdoing and seeking reconciliation that, absent the constraining hand of counsel, no sentence inducement is needed to persuade them to plead guilty. Prosecutors who seek to procure guilty pleas from current or future defendants brought before the Special Court for Sierra Leone, the Extraordinary Chambers in Cambodia, or the International Criminal Court will no doubt be confronted with a different array of factors that will impact the influence of sentencing discounts over those defendants.

This discussion elides the question of whether prosecutors should be seeking guilty pleas for international crimes. There is no question that plea bargaining constitutes one of the most disreputable features of the American criminal justice system. ${ }^{363}$ American charge bargaining frequently distorts the historical record of proceedings, ${ }^{364}$

363. See Combs, supra note 36 , at $4-5 \mathrm{n} .13$ (collecting critical sources). Plea bargaining is none too popular in other countries either. See Kathy Mack \& Sharyn Roach Anleu, Sentence Discount for a Guilty Plea: Time for a New Look, 1 FuINDERS J. L. REFoRM 123, 124 (1997) ("It is our conclusion that the sentence discount for a guilty plea as it currently operates in Australia is wrong in principle and in practice and should not be supported."); Kathy Mack \& Sharyn Roach Anleu, Choice, Consent and Autonomy in a Guilty Plea System, 17 L. CONTEXT 75, 75-76 (1999) (suggesting reform of the Australian plea-hargaining system to take account of defendants' diverse social identities); Willis, supra note 2, at 72 (recounting various criticisms of Australian plea bargaining); Murder Sentence Changes Unveiled, BBC NEWS, Sept. 20, 2004 (criticizing British plan to reduce a defendant's sentence by up to a third, following a guilty plea); Lincoln Archer, "We Feel We've Been Robbed," BBC NEws, Sept. 20, 2004 (same).

364. Some prosecutors systematically over-charge defendants so as to be able to withdraw charges during the bargaining process. See Albert W. Alschuler, The Prosecutor's Role in Plea Bargaining, 36 U. CHI. L. REV. 50, 89 (1968) (describing prosecutors who "charge robbery when they should charge larceny from the person, [who] charge grand theft when they should charge petty theft, [who] charge assault with intent to commit murder when they should charge some form of battery...") [hereinafter Alschuler, The Prosecutor's Role in Plea Bargaining]; Ruttenberg, supra note 38, at 325-26 (The prosecutor "may charge the defendant in the original indictment with a crime or crimes that he knows he cannot prove, and then, 'bargain' down to 
and any sort of plea bargaining can encourage prosecutors and defense attorneys to misrepresent facts and to bring frivolous motions to obtain a better plea. ${ }^{365}$ Moreover, as a result of the way in which most appointed counsel are compensated in the United States, plea bargaining gives rise to conflicts of interest whereby defense counsel have strong incentives to pressure their clients to plead guilty, regardless of whether it is in their best interests to do so. ${ }^{366}$ Many of

the charges for which he has the necessary proof."); Frase, supra note 236, at 621 (noting that American prosecutors "have an incentive to exaggerate initial charges so as to leave more room for later plea bargaining concessions"); see also Robert E. Scott \& William J. Stuntz, Plea Bargaining as Contract, 101 YALE L.J. 1909, 1963-66 (1992) (observing that mandatory minimum sentencing schemes provide useful bargaining positions for the prosecutor, who may then obtain a guilty plea for a lesser crime that, in fact, more accurately represents the defendant's conduct). Other prosecutors issue accurate indictments but withdraw charges in a way that understates the actual criminal responsibility. John H. Langbein, Torture and Plea Bargaining, 46 U. CHI. L. REV. 3, 16 (1978) ("In the plea bargaining that takes the form of charge bargaining (as opposed to sentence bargaining), the culprit is convicted not for what he did, but for something less opprobrious."); Alschuler, Trial Judge's Role, supra note 11, at 1141 (observing that charge bargaining frequently mislabels the conduct that it punishes so that "[g]uns are 'swallowed' as armed robberies become unarmed robberies; burglaries committed at night are transformed through prosecutorial wizardry to burglaries during the day; and defendants solemnly affirm that they have driven the wrong way on one-way streets in towns without one-way streets").

365. Prosecutors might, for instance, conceal fatal defects in the case, such as that a critical witness has died, will not testify, or cannot be found. See Alschuler, The Prosecutor's Role in Plea Bargaining, supra note 364, at 65-67; see also William F. McDonald et al., Prosecutorial Bluffing and the Case Against Plea-Bargaining, in PLEA BARGAINING 1, 9 (William F. McDonald \& James A. Cramer eds., 1980); Fred C. Zacharias, Justice in Plea Bargaining, 39 WM. \& MARY L. Rev. 1121,1149 (1998). Defense attorneys, for their part, frequently demand jury trials when they have no interest in trying the case before a jury. Alschuler, The Prosecutor's Role in Plea Bargaining, supra note 364 , at 56 . They also often file numerous pre-trial motions in an effort to enhance their own bargaining positions. Id. at 80; see Kenneth Kipnis, Criminal Justice and the Negotiated Plea, 86 ETHICs 93, 94 (1976) ("A skilled defense attorney can do much to force the prosecutor to expend resources in bringing a case to trial.").

366. The conflicts of interest arise because American defense counsel are compensated in ways that motivate them to dispose of virtually all of tbeir cases through guilty pleas. Retained defense attorneys typically obtain a flat fee, paid up-front, for their representation. David Lynch, The Impropriety of Plea Agreements: A Tale of Two Counties, 19 LAW. \& SOC. 1NQUIRY 115, 123 \& n.9 (1994). That fee is always sufficient, and frequently generous, for the work involved in securing a guilty plea. Albert W. Alschuler, The Defense Attorney's Role in Plea Bargaining, 84 YALE L.J. 1179, 1182-84 (1975). But it is often woefully inadequate as compensation for taking a case to trial. See Schulhofer, supra note 1, at 1988; Stephen J. Schulhofer, A Wake-Up Call from the Plea Bargaining Trenches, 19 LAW. \& SOC. INQUIRY 135, 138 (1994); Stephen J. Schulhofer, Criminal Justice Discretion as a Regulatory System, 17 J. LEGAL STUD. 43, 53-54 (1988) (noting that because retained lawyers are typically paid a flat fee up front, when they take a case to trial, their "additional bours of effort typically have to be provided free of charge"); Alschuler, The Defense Attorney's Role, supra at 1181-1206 (describing the retained defense attorneys' incentive to convince their clients to plead guilty); Gordon van Kessel, Adversary Excesses in the American Criminal Trial, 67 NOTRE DAME L. REV. 403, 502 (1992) (noting that retained attorneys "make more money disposing of cases by plea bargain than by trial" and that some "lawyers complain of "losing money by going to trial"); Chad Baruch, Through The Looking Glass: A Brief Comment on the Short Life and Unhappy Demise of the Singleton Rule, 27 N. KY. 
these abuses also have the potential to wreak havoc in the international context, and the hue and cry that greeted the sentences imposed in certain ICTY guilty-plea cases $^{367}$ suggest a similar level of public dissatisfaction with plea bargaining in that realm.

The desirability of plea bargaining in the international realm is not a topic that can be addressed here. ${ }^{368}$ Whatever its desirability, what can be observed is that in a national criminal justice system, defendants who are not motivated by sentence discounts would spell the end of efforts to secure guilty pleas because sentence discounts are the only real inducement that national prosecutors have to offer. International prosecutors, however, have at their disposal additional incentives. For some international defendants, the location of detention can matter more than the length of detention. Likewise, where there is more than one criminal justice system available to prosecute the defendant, the question of which one takes the honors can be of key significance. Bargaining over these issues may be more easily conducted outside the public glare, thereby benefiting prosecutors accustomed to public rebuke for their lenient sentence

L. REV. 841, 850 (2000) (noting that court appointed defense attorneys and those paid a flat fee who proceed to trial "take[ the risk of earning as little as one or two dollars per hour."); Jerome H. Skolnick, Social Control in the Adversary System, 11 J. CONFLICT RES. 52, 61 (1967) (noting the economic advantage that can accrue to the private attorney who pleads her client guilty).

Lawyers who are appointed to represent indigent defendants have similarly compelling incentives to convince their clients to plead guilty. Appointed counsel are typically paid either a flat fee or an hourly rate with a ceiling. Whichever form the compensation takes, the amounts are embarrassingly low. Nancy J. Moore, The Ethical Duties of Insurance Defense Lawyers: Are Special Solutions Required?, 4 CONN. INS. L.J. 259, 290 (1997-1998) ("T]n criminal defense work, flat fees are common for lawyers representing indigent defendants, and the rates are outrageously low, especially in death penalty cases."). Appointed defense attorneys in New York County, New York, for instance, are paid "\$40 per hour for in-court work and $\$ 25$ per hour for out-of-court work, with caps of $\$ 1,200$ for felony cases and $\$ 800$ for misdemeanor cases." Terry Brooks \& Shubhangi Deoras, Local Bars Fight to Hike Counsel Rates, 17 CRIM. JUST. 42, 42 (2002). Because the compensation caps are almost always the same regardless of whether the defendant pleads guilty or goes to trial, appointed defense counsel have enormous incentives to dispose of as many cases as possible by guilty plea. Schulhofer, Plea Bargaining as Disaster, supra note 1, at 1989; Bruce W. Neckers, Michigan's System of Compensation for Criminal Defense of the Indigent is Inadequate, $81 \mathrm{MICH}$. BAR J. 8 (Jan. 2002) ("Those serving indigent defendants in counties with flat rates, or 'fee schedules,' are faced with a disturbing disincentive to serve their clients well because in most cases the lawyer receives a maximum amount for the type of service rendered despite the time it takes to render the service.").

367. See supra note 137.

368. I will briefly note, however, that international criminal prosecutions labor under pressures unknown to domestic criminal courts. The Special Panels closed its doors in May 2005, leaving many defendants unprosecuted. Attempts to secure guilty pleas in this context, then, must be evaluated by entirely different criteria. See NANCY AMOURY COMBS, GUILTY PLEAS IN InTERnational Criminal LAW: CONSTRUCTING A Restorative JUSTICE APProach For BRIDGING JUSTICE AND TRUTH (forthcoming 2006) (arguing, among other things, that plea bargaining is justifled in the context of international crimes as a means of enhancing the penological goals that international criminal prosecutions are intended to serve). 
recommendations in guilty-plea cases but creating an additional worry for those already uneasy about plea bargaining. Whether the offer of such inducements will or should be the next frontier in international plea bargaining cannot yet be known. What is currently clear, however, is that international prosecutors who wish to procure guilty pleas must be more flexible and more creative in their efforts if they are to counterbalance the many factors that can deter international defendants from pleading guilty. 